\title{
13. SEDIMENT MICROFABRIC AND PHYSICAL PROPERTIES RECORD OF LATE NEOGENE POLAR FRONT MIGRATION, SITE 751 ${ }^{1}$
}

\author{
Frank R. Rack² and Amanda Palmer-Julson²
}

\begin{abstract}
Through scanning electron microscope analysis of sediment microfabric, we have evaluated variations in high-resolution shipboard physical properties (index properties and shear strength), sediment components (smear slide determinations), and shore-based calcium carbonate and biogenic silica data from Site 751 (Kerguelen Plateau). The stratigraphic section at this site records a change in biogenic ooze composition from predominantly calcareous (nannofossil) to siliceous (diatom) ooze from $\sim 23 \mathrm{Ma}$ to the present, reflecting expansion of Antarctic water masses during the late Neogene. The profound change in physical properties and sediment character at $40.1 \mathrm{mbsf}(\sim 5-6 \mathrm{Ma})$ evidently records the northward movement of the Polar Front and a change in absolute accumulation rates of sediment at this site.

Trends in geotechnical properties with depth at Site 751 allowed us to subdivide the sedimentary column into a number of geotechnical units that reflect changes in depositional and postdepositional processes with time. Geotechnical properties are sensitive to changing sedimentary inputs of primarily siliceous and calcareous microfossils. This allows us to study the physical nature of biostratigraphically-identified hiatuses and variations in environmental conditions linked to the migration of the Polar Front across this region. The analysis of geotechnical properties permits a more detailed division of the sedimentary column than is possible from shipboard lithologic descriptions alone.

Our study of the sedimentary microfabric indicates that randomly oriented, elongate pennate diatom valves compose the sediments with highest porosity and water content values, and the lowest density values (wet bulk, dry bulk, and grain density). Conversely, sediments composed of nannofossils and disassociated nannofossil crystallites and little or no siliceous remains have the lowest porosity and water content values, and the highest density values. Samples of mixed siliceous/calcareous composition have intermediate physical property values, but these vary according to the nature of the sedimentary matrix and the state of preservation of individual skeletal elements.
\end{abstract}

\section{INTRODUCTION}

Most previous investigations of the Antarctic Polar Front have involved biostratigraphic, isotopic, taxonomic, or quantitative faunal analyses. In this study, we establish a geotechnical stratigraphy for Site 751 and evaluate variations in physical properties with depth as a record of paleoenvironmental changes.

Geotechnical stratigraphy has been defined as "the study of a vertical succession of sediment characteristics such as index properties (wet- and dry-bulk density, grain density, porosity, and water content), state and behavior of consolidation, strength parameters, and other inherent physical and mechanical properties that identify a distinct aspect of a given sedimentary unit" (Taylor, 1984). Taylor (1984) established criteria for geotechnical analyses that were based on identifying zones having similar downhole trends in properties. These zones had distinct boundaries separating them from one another, thus delineating geotechnical units and/or subunits. The boundaries for geotechnical units were identified by trend reversals, inflections of a particular trend, or by discontinuities in geotechnical properties.

We define geotechnical subunits for Site 751 using the criteria described above (see Table 1). The use of geotechnical subunits provides a coherent framework that can be used to interpret subtle changes in the sedimentary record at this site,

\footnotetext{
${ }^{1}$ Wise, S. W., Jr., Schlich, R., et al., 1992. Proc. ODP, Sci. Results, 120: College Station, TX (Ocean Drilling Program).

2 Ocean Drilling Program, Texas A\&M University, College Station, TX
}

which are observed as variations in physical properties. We also calculate accumulation rates using dry-bulk density data and linear sedimentation rates derived from shipboard biostratigraphy and magnetostratigraphy. (Age assignments used in the text of this paper are from Harwood and Maruyama, this volume). Accumulation rate data (Appendix A) provide a basis by which we can evaluate changing fluxes of individual sedimentary components, which reflect variations in surfacewater paleoproductivity, microfossil preservation, and the accumulation of inorganic materials such as ice-rafted debris (IRD). In addition, we address changes in the sedimentary microfabric with regard to the sedimentary and environmental conditions represented at this site.

\section{Oceanographic Setting}

The Antarctic Circumpolar Current (ACC) system can be described as a zonal sequence of strong currents (expressed as multiple narrow jets) and contrasting water masses, separated by density fronts, which appear to be circumpolar in extent (Emery, 1977; Hofmann, 1985; Nowlin and Klinck, 1986) (Fig. 1). Changes in ACC mean transport rates are related to latitudinal displacements of the frontal systems (Whitworth, 1983), which serve as boundaries between various water masses, and extend with little attenuation to the sea floor. The geographic position of the respective fronts are known to vary from one basin to another, according to Gordon et al. (1978) and Gordon and Molinelli (1982); these and other review papers note that migrations of the Antarctic Polar Front (or simply "Polar Front" in this paper) should be considered in the context of the entire ACC system.

The oceanographic fronts of importance to this paper are the Antarctic Divergence (AD), the Polar Front (PF), and the 
Table 1. Geotechnical stratigraphic units, Site 751.

\begin{tabular}{lccccccc}
\hline $\begin{array}{l}\text { Subunit } \\
\left(\mathrm{g} / \mathrm{cm}^{3}\right)\end{array}$ & $\begin{array}{c}\text { Depth } \\
(\mathrm{mbsf})\end{array}$ & $\begin{array}{c}\text { Water content } \\
(\% \text { wet wt) }\end{array}$ & $\begin{array}{c}\text { Porosity } \\
(\%)\end{array}$ & $\begin{array}{c}\text { Wet-bulk } \\
\text { density } \\
\left(\mathrm{g} / \mathrm{cm}^{3}\right)\end{array}$ & $\begin{array}{c}\text { Dry-bulk } \\
\text { density }\end{array}$ & $\begin{array}{c}\text { Grain } \\
\text { density } \\
\left(\mathrm{g} / \mathrm{cm}^{3}\right)\end{array}$ & $\begin{array}{c}\text { Carbonate } \\
\text { content }(\%)\end{array}$ \\
\hline G-Ia & $00.00-9.50$ & $81.84-48.88$ & $91.50-70.98$ & $1.49-1.12$ & $0.76-0.20$ & $2.58-1.89$ & $71.46-00.00$ \\
G-Ib & 14.40 & 20.18 & 35.11 & 1.81 & 1.45 & 2.17 & \\
G-Ic & $14.90-39.90$ & $81.57-56.81$ & $90.57-71.91$ & $1.30-1.17$ & $0.51-0.22$ & $2.72-1.61$ & $24.39-00.00$ \\
G-IIa & $40.35-52.00$ & $48.02-40.20$ & $70.83-63.40$ & $1.65-1.48$ & $0.97-0.77$ & $2.71-2.37$ & $84.34-59.92$ \\
G-IIb & $54.00-60.40$ & $43.96-35.76$ & $68.19-59.91$ & $1.76-1.55$ & $1.13-0.87$ & $2.82-2.42$ & $90.84-77.81$ \\
G-IIc & $60.85-76.00$ & $56.95-46.20$ & $74.75-68.07$ & $1.54-1.37$ & $0.82-0.59$ & $2.65-2.15$ & $78.77-42.94$ \\
G-IId & $76.40-90.90$ & $48.12-38.17$ & $70.46-61.36$ & $1.68-1.51$ & $1.04-0.80$ & $2.74-2.38$ & $84.83-67.53$ \\
G-IIe & $91.35-94.35$ & $39.63-37.17$ & $63.48-59.55$ & $1.72-1.64$ & $1.07-0.99$ & $2.82-2.55$ & $91.72-85.10$ \\
G-IIf & $95.00-102.35$ & $54.44-41.42$ & $74.73-64.46$ & $1.63-1.39$ & $0.95-0.64$ & $2.67-2.22$ & $84.82-42.90$ \\
G-IIg & $103.00-109.00$ & $53.81-39.60$ & $73.15-63.02$ & $1.67-1.39$ & $1.01-0.64$ & $2.63-2.35$ & $71.04-25.90$ \\
G-IIh & $109.90-120.00$ & $56.81-33.59$ & $74.24-57.74$ & $1.84-1.37$ & $1.21-0.59$ & $2.89-2.20$ & $94.48-24.25$ \\
G-IIi & $120.50-125.00$ & $38.03-34.58$ & $62.00-58.09$ & $1.78-1.65$ & $1.16-1.05$ & $2.81-2.51$ & $94.48-81.85$ \\
G-IIj & $125.40-128.00$ & $51.51-40.80$ & $72.61-63.26$ & $1.62-1.48$ & $0.96-0.72$ & $2.79-2.52$ & $72.43-47.53$ \\
G-IIk & $128.40-139.90$ & $45.16-36.37$ & $67.17-60.57$ & $1.76-1.54$ & $1.12-0.85$ & $2.78-2.35$ & $88.99-62.03$ \\
G-III & $140.35-149.85$ & $40.25-36.22$ & $63.21-59.57$ & $1.76-1.67$ & $1.11-1.00$ & $2.95-2.50$ & $92.61-87.59$ \\
G-IIm & $150.50-164.50$ & $48.75-37.45$ & $70.77-60.28$ & $1.74-1.51$ & $1.08-0.77$ & $2.80-2.46$ & $93.18-66.75$ \\
\hline
\end{tabular}



Figure 1. Location map showing the Kerguelen Plateau and the position of Site 751 .

Subtropical Convergence (STC). The AD, nearest the Antarctic continent, is characterized by upwelling and the formation of cold Antarctic Surface Water, which flows north toward the PF (Gordon et al., 1978). The PF, or Antarctic Convergence, is marked by a complex stratification between antarctic and subantarctic waters, and the downwelling of surface water to form Antarctic Intermediate Water. The PF exists where the water temperature minimum dips sharply below the $200 \mathrm{~m}$ level, and a salinity minimum $(34.0 \% 0-34.1 \%$ is present. Subantarctic Surface Water flows northward, away from the PF, and sinks near the STC (Gordon et al., 1978). Variations in Subantarctic Surface Water (bounded by the STC and PF) are linked to simultaneous changes in the position and inten- sity of the westerly winds and sea surface temperatures (Fletcher et al., 1982).

In this study, we have evaluated the history of Polar Front migrations at Site 751 by using geotechnical stratigraphy to reveal latitudinal shifts of pelagic sedimentary facies. Such facies shifts have been linked to Neogene movements of the PF and STC by Hayes et al. (1976), Wise et al. (1982), Ciesielski and Weaver (1983), Williams et al. (1985a, 1985b), Ciesielski and Grinstead (1986), and Morley (1989) among others. These and other studies have shown that the northern boundary of the siliceous facies is marked by a change to calcareous deposition coincident with the location of the Subtropical Convergence. The southern boundary of the siliceous facies is generally acknowledged to be coincident with the Antarctic Divergence ( $\sim 60^{\circ} \mathrm{S}$ in the Atlantic and Indian oceans), and is marked by a change to terrigenous sediment associated with the mean position of Antarctic sea ice (Cooke and Hays, 1982). Most terrigenous material deposited north of the AD and south of the PF, such as at Site 751, has therefore been transported primarily by wind or ice (see Breza, this volume for discussion of Neogene IRD). Furthermore, the bulk of the biogenic opal that is incorporated into the geologic record accumulates in a latitudinal belt around Antarctica between $45^{\circ}$ and $65^{\circ} \mathrm{S}$; thus making shifts in this facies highly significant for global fluxes of silica over time (Lisitzin, 1972, 1985; DeMaster, 1979, 1981; Barron and Baldauf, 1989).

\section{Site $\mathbf{7 5 1}$}

Site 751 (Fig. 1) is located at $57^{\circ} 43.56^{\prime} \mathrm{S}, 79^{\circ} 48.89^{\prime} \mathrm{E}$, in $1633.3 \mathrm{~m}$ of water, $900 \mathrm{~km}$ south of the present-day position of the Polar Front (at $50^{\circ} \mathrm{S}$, the latitude of Kerguelen Island). Schlich, Wise, et al. (1989) described two sedimentary units from this site (see Fig. 2):

Unit I (0-40.1 mbsf): upper Pleistocene ( $>0.2 \mathrm{Ma})$ to lower Pliocene (to upper Miocene?) diatom ooze with minor amounts of ice-rafted debris, foraminifers, volcanic ash, and porcellanite.

Unit II (40.1-166.2 mbsf): upper Miocene to lower Miocene diatom nannofossil ooze.

As discussed by Schlich, Wise, et al. (1989), the sedimentary section at this site records the late Neogene glacial history of Antarctica (and consequent expansion of Antarctic water masses) reflected as a facies change from nannofossil ooze to diatom ooze. Unit II represents the $\sim 17 \mathrm{~m} . \mathrm{y}$. 


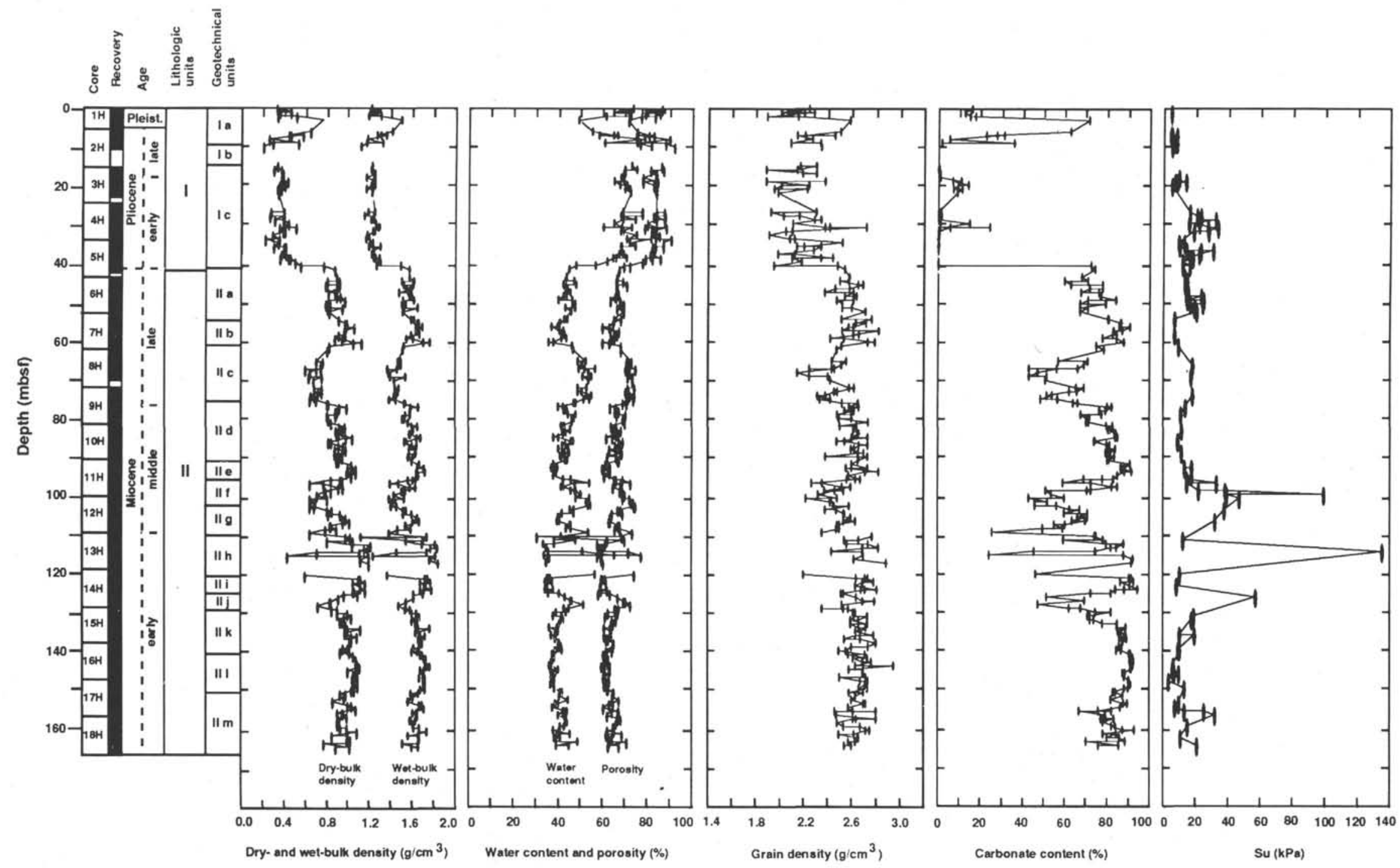

Figure 2. Profiles of index properties, carbonate content, and shear strength vs. depth for Site 751 . Core recovery and relative age of section is shown to the left of the figure. Geotechnical subunits are also indicated. 
( $\sim 23-\sim 6 \mathrm{Ma}$ ) during which $126.1 \mathrm{~m}$ of predominantly calcareous ooze accumulated under the influence of earlier water masses. A disconformity ( $2.5 \mathrm{~m}$.y., from 8.4-5.9 Ma) exists between the units, marking the northward migration of the PF across the Site 751 location. Above the disconformity, $40.1 \mathrm{~m}$ of biosiliceous ooze accumulated during the ensuing $5.9 \mathrm{~m} . \mathrm{y}$. (5.9 Ma to present) under the influence of various Antarctic water masses.

This change in sedimentation regime is clearly demonstrated by the percentages of diatoms and nannofossils seen in smear slides of the sediment, geochemical (wt\% $\mathrm{CaCO}_{3}$ and $\mathrm{SiO}_{2}$ ), and physical property data (porosity, bulk density, and grain density) (Figs. 2 and 3). However, subtle variations also appear in these data, suggesting that a record of climatic history may be present throughout the sequence. Our geotechnical stratigraphic analysis was particularly valuable for revealing these less distinct variations.

We examined nine representative samples with the scanning electron microscope (SEM) (see Table 2) and evaluated our observations with reference to physical properties and sedimentological data from the sediments. Our intention was to investigate how and why variations in the physical properties data corresponded to changes in sediment composition; in particular, we were interested in fluctuations in the twocomponent (silica vs. carbonate) nature of Site 751 sediments, which the Leg 120 shipboard party interpreted as representing climatic fluctuations (i.e., Polar Front migrations) (see Schlich, Wise, et al., 1989).

A cursory review of the data (Figs. 2 and 3) indicates striking differences in physical properties correlated with sediment composition: siliceous sediments have higher porosity and water content values, and lower wet-bulk, dry-bulk, and grain density values than do calcareous sediments. Similar observations have been made by previous investigators (e.g., Schreiber, 1968; Hamilton, 1976; Shephard and Bryant, 1980; Bryant et al., 1981; Wilkens and Handyside, 1985; Wilkens et al., 1987; Pittenger et al., 1989; among others). In addition, the apparent consolidation state (as illustrated by a plot of the $\mathrm{S}_{\mathrm{u}}$ /overburden stress ratio) and bulk accumulation rate of sediments are shown to be inversely related; with higher bulk sediment accumulation observed as apparent underconsolidation, and lower bulk accumulation resulting in overconsolidated or normally consolidated sediment sequences (Fig. 3). We were interested in how the orientation and interrelation of discrete particles (skeletons or skeletal elements) influences the physical properties of the sediment, which led us to investigate the microfabric of the oozes.

Previous studies of the sedimentary fabric and its effects on geotechnical properties have typically focused on nonbiogenic sediments, especially clays (e.g., see review in Bennett et al., 1977). However, there have been few fabric studies of biogenic sediments, although biosiliceous sediments, in particular, demonstrate intriguing physical properties that are clearly related to sediment fabric characteristics. For example, the porosity and density of biosiliceous sediment may remain unchanged with depth because the porous, rigid, siliceous skeletons resist the compaction that typically occurs in other sediment types in response to overburden load (Hamilton, 1976; Shephard and Bryant, 1980; Bryant et al., 1981; Wilkens and Handyside, 1985; Wilkens et al., 1987; Pittenger et al., 1989).

In the following sections, we (1) discuss our methods of sample selection and analysis, (2) present a geotechnical stratigraphy for Site 751 , (3) present a summary of the physical properties data, microfabric, and calculated accumulation rates, (4) present an overall summary and discussion of our results as a record of the movement of the Polar Front in response to the late Neogene climate history of the Southern Ocean.

\section{METHODS}

High-resolution measurements of physical properties (index properties and shear strength), calcium carbonate, and smearslide data were obtained from shipboard analyses detailed in the "Explanatory Notes" chapter (Schlich, Wise, et al., 1989). We performed additional carbonate analyses of the index property samples on a coulometer similar to the one aboard the JOIDES Resolution. These data increase the resolution of the shipboard carbonate profile and provide a check on the shipboard values measured in rough seas during the cruise. Biogenic silica (opal) contents were determined by D. DeMaster, University of North Carolina using the sodium carbonate leaching method described by DeMaster $(1979,1981)$.

We selected nine of the physical properties samples for SEM analysis. These samples were chosen to represent sedimentary intervals that we found to have distinctive physical properties, with one or two samples taken from each interval. Note that no samples were taken from Cores $120-751 \mathrm{~A}-1 \mathrm{H}$ to $-3 \mathrm{H}$ because these had extremely high water contents and it proved impossible to obtain undisturbed material. The samples we chose were trimmed and oriented so that we could identify the direction of bedding. We also studied smear slides of these samples to make direct correlations of results.

Samples for SEM analysis were oven dried and coated with $\mathrm{Au}-\mathrm{Pd}$. They were mounted on aluminum stubs perpendicular to bedding (the orientation of the stratigraphic "up" direction was lost, but this information was not critical for the purposes of our investigation). Samples were examined using the JEOL instrument at the Texas A\&M Electron Microscopy Center at 10-15 $\mathrm{kV}$; an energy-dispersive X-ray spectrographic analyzer was used to study carbon-coated splits of selected samples.

\section{RESULTS}

\section{Introduction}

The goal of a geotechnical stratigraphic analysis is to integrate measured physical and mechanical properties of the sediments from a particular site with geochemical data and calculated bulk accumulation rates, to provide a better understanding of the depositional history of a given sedimentary sequence. This approach has been used to describe the sedimentary sections from numerous DSDP and ODP drill sites.

Recently, attention has been focused on sedimentary sequences that contain biogenic silica in high-latitude regions such as the Vøring Plateau (Leg 104; Eldholm, Thiede, Taylor, et al., 1987, 1989), the Weddell Sea (Leg 113; Barker, Kennett, et al., 1988, 1990), across the South Atlantic (Leg 114; Ciesielski, Kristoffersen, et al., 1988), and along the length of the Kerguelen Plateau (Legs 119 and 120; Barron, Larsen, et al., 1989, and Schlich, Wise, et al., 1989, respectively). These sequences demonstrate the anomalous nature of biosiliceous sediment properties (see Schreiber, 1968; Hamilton, 1976; Bryant et al., 1981; Wilkens et al., 1987) compared with those of clays or carbonates, where, typically, porosity decreases and density increases with increasing depth and overburden pressure.

We evaluated the physical properties data from Site 751 and identified geotechnical subunits as follows: three in lithologic Unit I and 13 in lithologic Unit II (Table 1 and Figs. 2 and 3). These subunits reveal contrasts in sediment composition because siliceous sediments have lower wet-bulk, dry-bulk, and grain density values and higher porosity and water content values than calcareous sediments. In the following sec- 

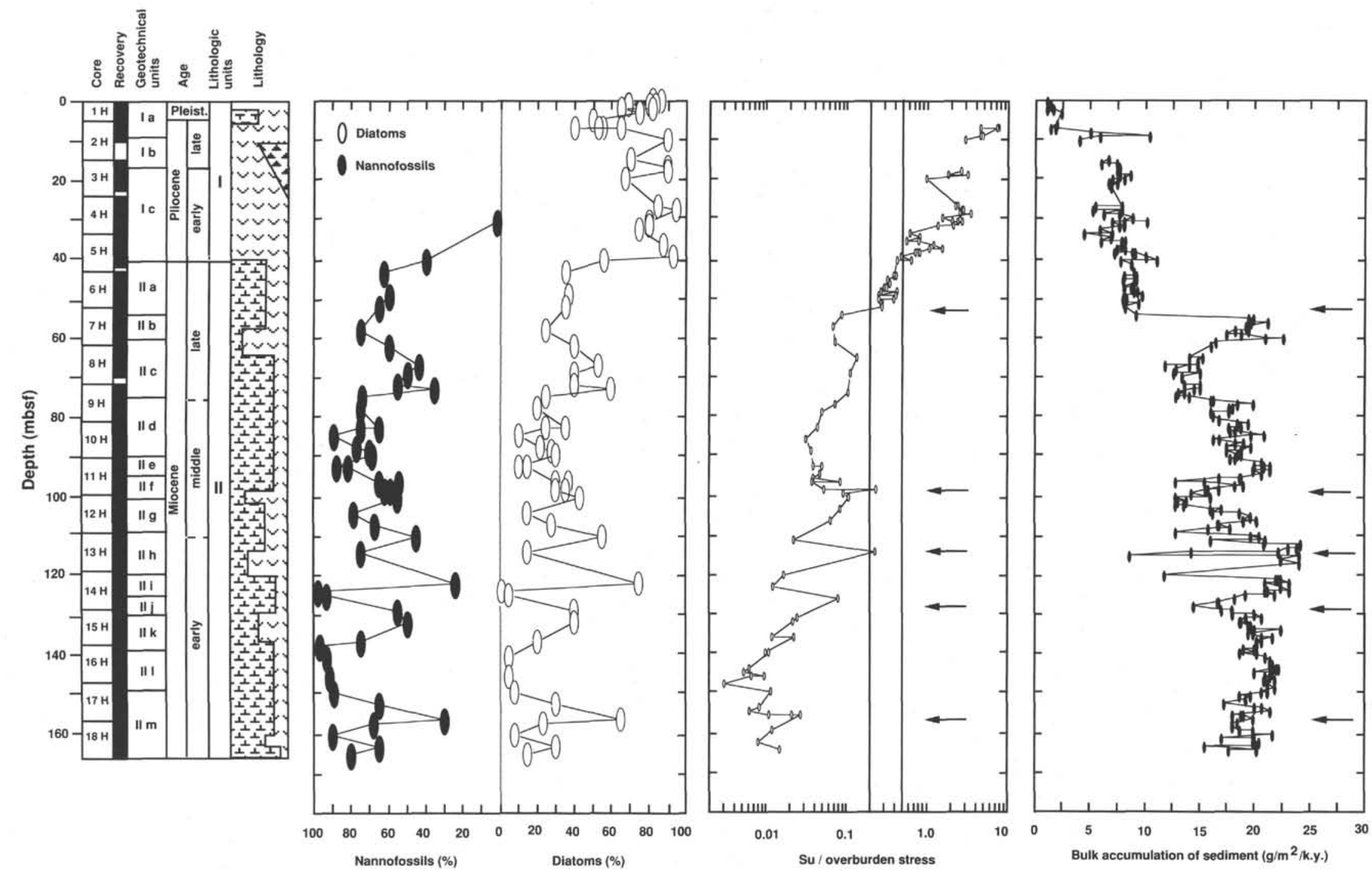

Figure 3. Smear slide data of diatom and nannofossil content vs. depth compared with shear strength/overburden stress ratio, and bulk accumulation of sediment vs. depth. Core recovery, relative age, geotechnical units and lithologies are also shown. Arrows indicate intervals where decreases in bulk-accumulation of sediment correspond with increased consolidation in Unit II. 
Table 2. Data from samples investigated with the SEM, Site 751.

\begin{tabular}{|c|c|c|c|c|c|c|c|c|c|c|c|c|c|}
\hline \multirow{2}{*}{$\begin{array}{l}\text { Core, section, } \\
\text { interval }(\mathrm{cm})\end{array}$} & \multirow{2}{*}{$\begin{array}{l}\text { Depth } \\
\text { (mbsf) }\end{array}$} & \multirow[b]{2}{*}{ Age } & \multicolumn{5}{|c|}{$\begin{array}{c}\text { Biogenic } \\
\text { components (\%) }\end{array}$} & \multirow{2}{*}{$\begin{array}{c}\mathrm{CaCO}_{3} \\
(\%)\end{array}$} & \multirow{2}{*}{$\begin{array}{l}\mathrm{SiO}_{2} \\
(\%)\end{array}$} & \multirow{2}{*}{$\begin{array}{c}\text { Porosity } \\
(\%)\end{array}$} & \multirow{2}{*}{$\begin{array}{l}\text { Wet-bulk } \\
\text { density } \\
\left(\mathrm{g} / \mathrm{cm}^{3}\right)\end{array}$} & \multirow{2}{*}{$\begin{array}{c}\text { Dry-bulk } \\
\text { density } \\
\left(\mathrm{g} / \mathrm{cm}^{3}\right)\end{array}$} & \multirow{2}{*}{$\begin{array}{c}\text { Grain } \\
\text { density } \\
\left(\mathrm{g} / \mathrm{cm}^{3}\right)\end{array}$} \\
\hline & & & D & R & $\mathrm{N}$ & SF & F & & & & & & \\
\hline \multicolumn{14}{|l|}{$120-751 \mathrm{~A}-$} \\
\hline $4 \mathrm{H}-4,67-69$ & 28.9 & early Pliocene & 95 & 2 & 0 & 1 & + & 0.3 & 62.1 & 83.86 & 1.24 & 0.38 & 2.34 \\
\hline $4 \mathrm{H}-6,30-32$ & 31.5 & early Pliocene & 75 & 2 & 0 & 1 & 0 & 0.2 & 64.5 & 82.49 & 1.23 & 0.38 & 2.10 \\
\hline $5 \mathrm{H}-5,70-72$ & 39.9 & e. Plio./l. Mio. & 93 & 6 & 0 & 0 & 0 & 0.1 & 45.4 & 71.91 & 1.37 & 0.55 & 1.95 \\
\hline $6 \mathrm{H}-1,70-72$ & 43.4 & late Miocene & 35 & 2 & 63 & 0 & 0 & 67.1 & 13.5 & 66.46 & 1.57 & 0.89 & 2.58 \\
\hline $6 \mathrm{H}-3,70-72$ & 46.4 & late Miocene & 37 & 3 & 60 & 0 & 0 & 71.2 & 13.3 & 65.76 & 1.59 & 0.89 & 2.46 \\
\hline $8 \mathrm{H}-5,30-32$ & 68.0 & late Miocene & 53 & 2 & 44 & 1 & 0 & 42.3 & 24.0 & 71.49 & 1.38 & 0.64 & 2.15 \\
\hline $8 \mathrm{H}-5,70-72$ & 68.4 & late Miocene & 40 & 1 & 50 & 1 & 0 & 42.3 & & 73.24 & 1.40 & 0.63 & 2.25 \\
\hline $12 \mathrm{H}-4,115-117$ & 105.4 & middle Miocene & 15 & 3 & 79 & + & + & 65.7 & 10.2 & 63.36 & 1.65 & 0.98 & 2.59 \\
\hline $13 \mathrm{H}-6,30-32$ & 117.0 & middle Miocene & 15 & + & 75 & + & 5 & 91.1 & 1.5 & 60.39 & 1.84 & 1.20 & 2.89 \\
\hline
\end{tabular}

Notes: Major component abundances as estimated from smear slides. $\mathrm{D}=$ diatoms, $\mathrm{R}=$ radiolarians, $\mathrm{N}=$ nannofossils, $\mathrm{SF}=$ silicoflagellates, $\mathrm{F}=$ foraminifers (or foraminifer fragments).

tion, we discuss the important results of our geotechnical stratigraphy.

\section{Index Properties}

The shipboard physical-properties program completed at Site 751 was designed to provide high-resolution $(50-\mathrm{cm}$ sample spacing) profiles of index properties to investigate the detailed behavior of biogenic oozes deposited during the Neogene in the Raggatt Basin. In addition, this site provided the opportunity to investigate changes in index properties over most of the range of natural carbonate contents from $0 \%$ to $100 \%$. This fortuitous situation allowed the relationships between percentage of calcium carbonate and index properties to be determined for the $\sim 165$-m-thick sequence at Site 751. Plots of individual index properties vs. carbonate content show strong correlations between these measurements (Figs. 4-6). Over the range of carbonate contents measured, the following nonlinear regression equations were determined for individual index properties at Site 751 on the basis of calcium carbonate percentage:

$$
\begin{aligned}
W B D & =2.592 \times 10^{-5}\left(x^{2}\right)+0.003(x)+1.216, r^{2}=0.901 \\
D B D & =3.046 \times 10^{-5}\left(x^{2}\right)+0.005(x)+0.345, r^{2}=0.919 \\
G D & =2.617 \times 10^{-5}\left(x^{2}\right)+0.003(x)+2.160, r^{2}=0.720 \\
P O R & =-3.186 \times 10^{-4}\left(x^{2}\right)-0.220(x)+84.45, r^{2}=0.899 \\
W C & =1.354 \times 10^{-4}\left(x^{2}\right)-0.387(x)+71.85, r^{2}=0.911 \\
\text { where } x & =\text { calcium carbonate percentage, } \\
\text { WBD } & =\text { wet-bulk density (gravimetric), } \\
\text { DBD } & =\text { dry-bulk density (gravimetric), } \\
\text { GD } & =\text { grain density, } \\
\text { POR } & =\text { porosity, and } \\
\text { WC } & =\text { water content. }
\end{aligned}
$$

According to the relationships derived in our study, depthrelated changes in index properties are controlled primarily by differences in lithology; these, in turn, are the result of changing environmental conditions on the Kerguelen Plateau. For example, the effects of compaction vary with depth as a result of changing microfossil assemblages and absolute accu- mulation rates: siliceous tests typically resist overburden forces more than do calcareous tests.

The poor correlation of carbonate content and grain density (relative to the other index properties) may result from the presence of ice-rafted and aeolian components, particularly in Lithologic Unit I (see Breza, this volume). However, it also may be a function of the calculation method (see Boyce, 1976), which is imprecise for high-porosity sediment. The relationships shown for index properties and carbonate content also apply to the majority of the observed siliceous vs. calcareous microfossil assemblage and sedimentological variations with depth. The close association between sedimentological and physical properties data at Site 751 allowed us to develop a detailed geotechnical stratigraphy that reflects the dynamic process of Neogene pelagic sedimentation in the central Raggatt Basin.

\section{State of Consolidation}

The sediments at Site 751 have low shear strengths, although values are somewhat higher than would be expected given such noncohesive, high-water content oozes at shallow burial depths. Higher shear strengths could also be an artifact caused by the drainage of fluid in the cores during testing (thus causing increased vane shearing resistance). Lee (1982) considered the effect of biogenic silica on the shear strength and bulk density of deep-sea calcareous sediments. He noted that the grain size and shape of pelagic sediments are controlled by productivity and dissolution factors; furthermore, the presence of biogenic silica has such a strong effect on the bulk density that the effects from variations in other sediment constituents are completely masked.

At Site 751, zones of increased shear strength correlate with increased water content (Fig. 7), and decreased bulk density and carbonate contents (Fig. 8). These trends are anomalous since shear strength normally increases with decreased water content and increased density in marine sediments (Bryant et al., 1981). Changes in the bulk accumulation rate of sediments are often inversely related to shear strength variations. The decreased accumulation of calcareous microfossils (possibly indicating dissolution of tests), and increased accumulation of siliceous microfossils, in zones of increased shear strength may point to a diagenetic cause for this trend. These zones of increased shear strength may also indicate the relative positions of sedimentary hiatuses.

Compaction effects are variable downhole because of the changing composition of microfossils and the typical resistance of siliceous tests to overburden forces that act upon them. A plot of void ratio to overburden stress shows the substantial decrease in the range of consolidation for the 

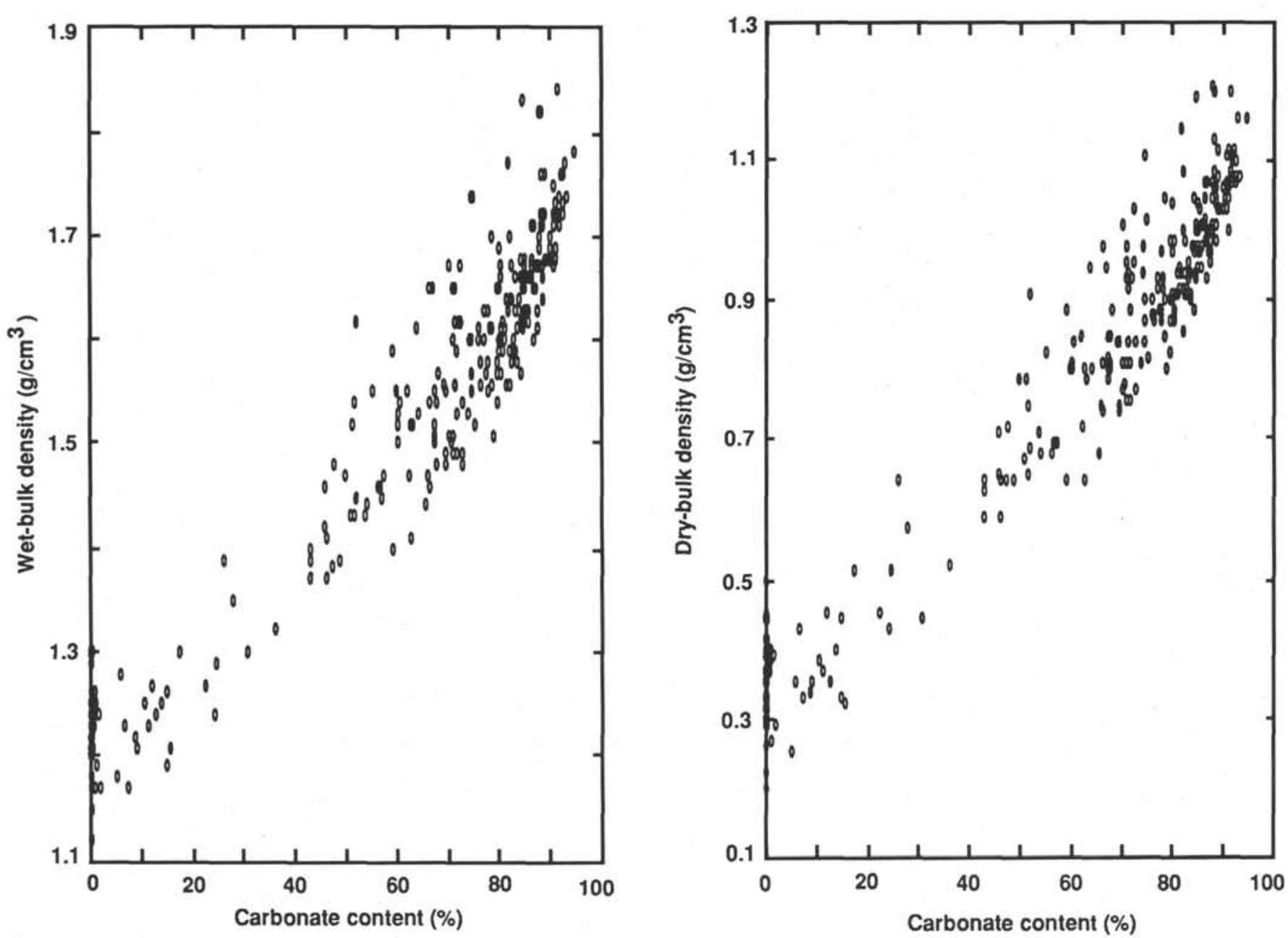

Figure 4. Scatter plots showing the relationship between laboratory wet- and dry-bulk density measurements and carbonate content of samples from Site 751.

calcareous ooze below $40.1 \mathrm{mbsf}$, as indicated by the large reduction in void ratio above $\sim 25 \mathrm{kPa}$ (Fig. 9).

A field consolidation curve of shear strength/effective overburden stress was calculated according to the relationship presented by Skempton (1970) for the sediment at Site 751 to evaluate their apparent state of consolidation (Fig. 10). Values of the ratio $\mathrm{S}_{\mathrm{u}}$ /overburden stress between 0.2 and 0.5 are interpreted to represent normally consolidated sediment; values $<0.2$ indicate underconsolidation and values $>0.5$ are considered to indicate overconsolidation.

The upper portion of this curve shows the sediment to be highly overconsolidated except in narrow zones that correlate to increases in water content and decreased carbonate content. This state of apparent overconsolidation is common in surficial marine sediments, but generally does not extend very far into the subsurface. The high values of the ratio of shear strength/ overburden stress observed in the upper $40 \mathrm{~m}$ at Site 751 may be the result of interlocking skeletal elements of elongate siliceous microfossils (i.e., diatoms). The framework developed by the siliceous skeletons, combined with the low bulk density of these highly porous deposits, reduces effective overburden pressures and thus increases the strength/stress ratio.

The shift to underconsolidated sediment at $\sim 52 \mathrm{mbsf}$ is linked to decreased porosity, increased carbonate content (i.e., presence of nannofossils), and increased bulk sediment accumulation in Subunit G-IIb with respect to Subunit G-IIa. The fine-grained calcareous matrix causes tight grain packing, which restricts fluid flow in this subunit. Reversals in the relative underconsolidation of lithologic Unit II are observed for Subunits G-IIc, G-IIf, G-IIh, and G-IIj, indicating more normal consolidation behavior correlated with increased biogenic silica content and decreased bulk accumulation rates. The higher permeability of siliceous ooze relative to carbonate ooze is likely to be the cause of this apparent increase in consolidation state. The shear-strength measurement interval became more widely spaced below $52 \mathrm{mbsf}$, however, we can identify two general trends: (1) increased underconsolidation with depth, and (2) narrow zones of increased relative consolidation within highly biosiliceous intervals (having $>\sim 40 \%$ diatoms).

\section{Water Content, Porosity, and Permeability}

Biogenically precipitated silica $\left(\mathrm{SiO}_{2} \cdot n \mathrm{H}_{2} \mathrm{O}\right)$ is not homogenous in nature. Density variations in opaline tests are related to water content, specific surface area, and age (Hurd and Theyer, 1977; Hurd et al., 1979). Wefer et al. (1982) estimate the bound water in diatomaceous opal from sediment traps in the Weddell Sea to be between 6 and 9 wt\%. DeMaster (1979) suggests that 


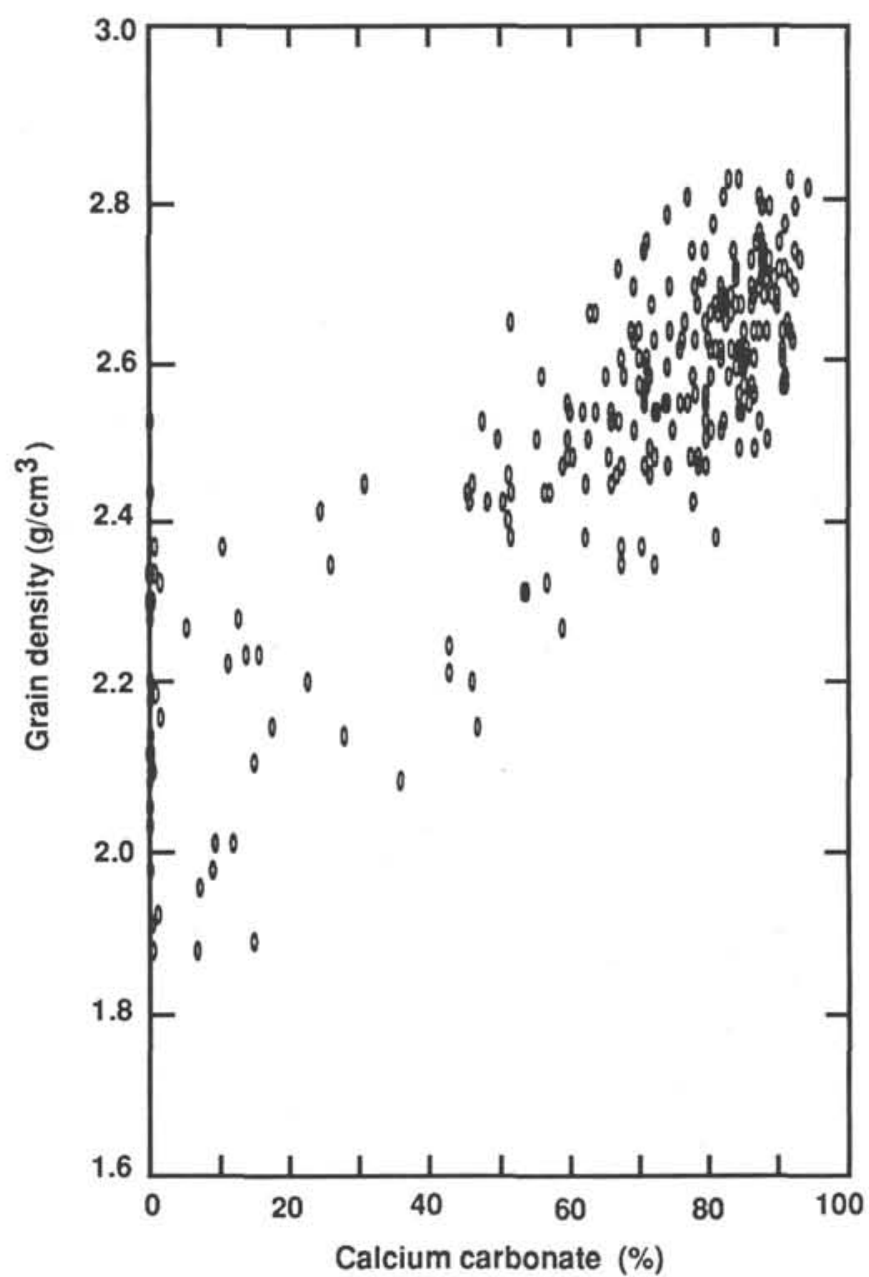

Figure 5. Scatter plot showing the relationship between laboratory grain density measurements and carbonate content of samples from Site 751 .

for Antarctic siliceous sediments containing 55 wt\% biogenic silica, $10 \%-15 \%$ of the remaining weight is attributable to bound water. This water must be taken into consideration when analyzing the physical properties of siliceous sediments.

Previous workers have evaluated the effects of inter- and intraparticle water on the physical properties of calcareous sediments. For example, Bachman (1984) found intraparticle water to be associated with foraminifers, but it appears to have no effect on geotechnical properties unless the particles are fractured during burial-induced loading (Demars, 1982).

Valent et al. (1982) proposed that the predominant compression mechanism in calcareous oozes is high, nonrecoverable deformation of the microfossil skeletons without physical breakage, as grain crushing was not observed in the natural specimens tested. However, Demars (1982) observed that foraminifer particles are susceptible to fracture when subjected to only moderate compressional stress, thereby releasing intraparticle water. Nannofossils are more likely to exhibit chipping rather than fracture at particle contacts, since larger particles transmit dynamic stresses and shield the fine-grained matrix (e.g., particles $>5 \mathrm{~mm}$ in diameter tend to fracture when absorbing contact forces) (Demars, 1982; Bennett et al., 1989). Nannofossils do, however, show changes in pore size and shape in response to mechanical compaction caused by overburden stress (e.g., dewatering and rearrangement of grains), thus creating denser packing arrangements (Bryant et al., 1981; Kim et al., 1985).

Bennett et al. (1989) discuss how packing arrangement can control permeability in calcareous oozes as the matrix of nannofossil crystallites creates small pores and restricted dewatering pathways. They measured permeability coefficients of $10^{-5}$ to $10^{-6} \mathrm{~cm} / \mathrm{s}$ (porosity $=54 \%-67 \%$ ) in calcareous sediments (composed of $\sim 10 \%$ foraminifers in a matrix of nannofossils) from Exuma Sound. Bryant and Rack (1990) present permeability coefficients for samples from Maud Rise (Sites 689 and 690, Leg 113) that are from $10^{-4}$ to $10^{-5} \mathrm{~cm} / \mathrm{s}$, for shallow-buried samples of diatom ooze, and from $10^{-5}$ to $10^{-7} \mathrm{~cm} / \mathrm{s}$, for underlying nannofossil oozes.

The high permeability of diatom ooze at low overburden pressures allows rapid drainage of fluid and, hence, results in the high degree of apparent overconsolidation observed in field consolidation curves. The data acquired from consolidation tests, using samples from Maud Rise, show the importance of intraskeletal porosity in shallow-buried diatom oozes. Diatomaceous sediments subjected to vertical stresses (up to $3200 \mathrm{kPa}$ ) exhibit a higher level of void reduction during testing than the calcareous samples, yet do not consolidate to as low a final void ratio (Bryant and Rack, 1990). The results obtained during consolidation testing of siliceous and calcareous oozes from Kerguelen Plateau are consistent with the findings from Maud Rise (Rack et al., unpubl. data).

Pittenger et al. (1989) demonstrate that for a given change in permeability, a greater degree of consolidation (decrease in void ratio) is observed for sediments with high biogenic silica contents than for other sediment types. The high percentage of intraskeletal and bound water in opaline tests may also help explain the resistance to compaction generally observed in diatomaceous deposits. If dissolution and/or breakage of tests releases intraskeletal and/or bound water (which can replace the water expelled by consolidation), then the effective vertical stress felt by the sediment will be reduced. This concept is important in explaining the underconsolidated state of sediments from the Vøring Plateau, although other factors (e.g., overlying low permeability clay-rich sediment) are also important (Pittenger et al., 1989). Our interest in how the orientation of discrete particles (skeletons or skeletal elements) influence the physical properties of the sediment led us to investigate the microfabric of these cores.

\section{Microfabric Analysis}

We examined nine samples utilizing the SEM, noting for each such features as (1) nature, condition, and orientation of the component particles; (2) relationship of matrix to larger grains; (3) degree of fragmentation, disarticulation, or disassociation of biogenic elements; (4) distribution of intra- and interparticle pore spaces; and (5) any other significant feature of the sedimentary fabric (detailed fabric descriptions for each SEM sample are presented in Appendix B; physical property data and component abundances are listed in Table 2). We thoroughly scanned each sample, noting fabric characteristics, and photographed representative features (e.g., diatom valves showing preferred orientation or articulation of valves and girdle bands); these are illustrated in Plates 1-5.

Biosiliceous sediments demonstrate intriguing physical properties clearly related to sedimentary microfabric. SEM analyses showed that some samples are predominantly composed of elongate, essentially intact pennate diatoms, whereas other samples are composed largely of centric diatom valves, and pennate diatoms are mostly represented by fragments. The matrix material in Unit I is primarily composed of fragmented diatoms; large skeletal fragments in these samples 

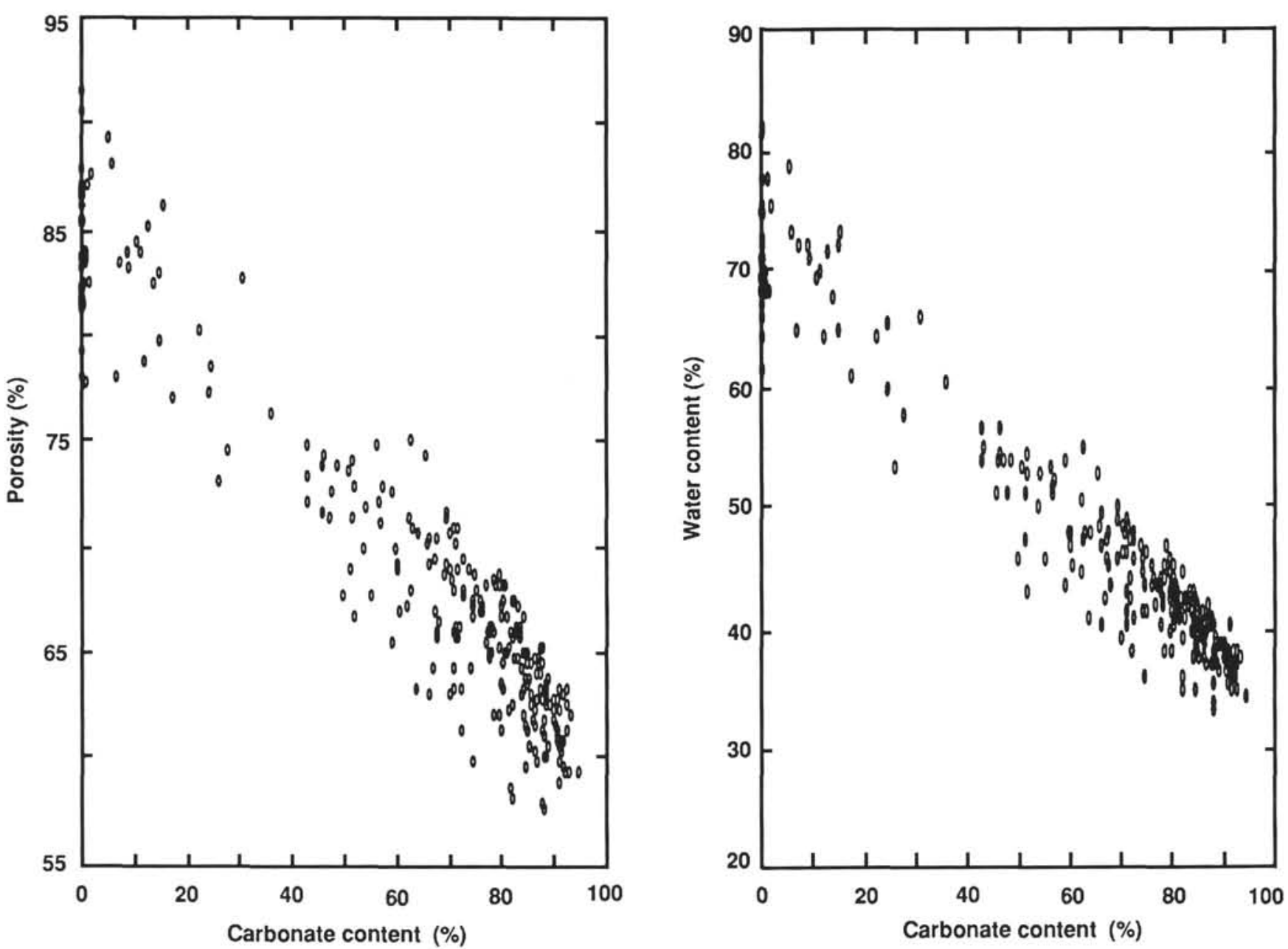

Figure 6. Scatter plots showing the relationship between laboratory measurements of porosity and water content and carbonate content for samples from Site 751 .

are scattered in the matrix, and are not generally in contact (even where clustered, as with the radiolarians). The almost complete absence of nannofossils and nannofossil fragments in this zone indicates the influence of carbonate-corrosive Antarctic waters.

We make the following summary observations of the microfabric with regard to the physical properties and sedimentological data from the samples (see Appendix B):

1. Porosity is positively correlated with diatom content and with $\mathrm{SiO}_{2}$ content; all the density measurements (wet-bulk, dry-bulk and grain density) are negatively correlated with porosity; elongate pennate diatoms create the most open, least dense fabric (e.g., Plates 1 and 2), as observed above 40.1 mbsf; below this level, centric diatoms create a less open, denser sediment (e.g., Plate 4), as reflected by lower porosity values and higher density values relative to the upper sequence.

2. Porosity is reduced in highly diatomaceous sediments in which the pore spaces of the individual tests are filled with matrix material or overgrown with authigenic minerals, such as those immediately above the major hiatus at $40.1 \mathrm{mbsf}$ (Plate 3, Figs. 1-3). The apparent inorganic silica (Opal- $\mathrm{A}^{\prime}$ ?) composition of this material appears to be responsible for the lack of difference in density values between samples of similar composition, with or without overgrowths.

3. Throughout the section, radiolarians are commonly filled with finer grained material than present in the surrounding matrix (e.g., Plate 1, Fig. 2) and may have shielded the fine material from winnowing. The loss of this potential pore space may reduce the overall porosity of the sediment (and weaken the correlation between silica content and porosity where radiolarians are a large component of the sediment).

4. Arthur et al. (1980) noted that bioturbation in diatomaceous sediments of the Japan Trench created a disordered fabric that caused the sediments to resist compaction and remain underconsolidated to $\sim 300 \mathrm{mbsf}$. In our samples, we typically found an overall disordered fabric, probably the result of bioturbation, but even in clearly bioturbated sediments (as noted in core descriptions) we saw some (relict?) evidence of preferred orientation (e.g., the alignment of long axes of diatom valves; Plate 1, Figs. 1-4). Bohrmann and Stein (1989) interpreted orientation of diatom valves to be the result of deposition directly from highly productive surface waters; they apparently did not consider bioturbation as a possible factor for creating a disordered fabric.

5 . Porosity is negatively correlated with nannofossil content and $\mathrm{CaCO}_{3}$ content in these sediments. Nannofossils pack 


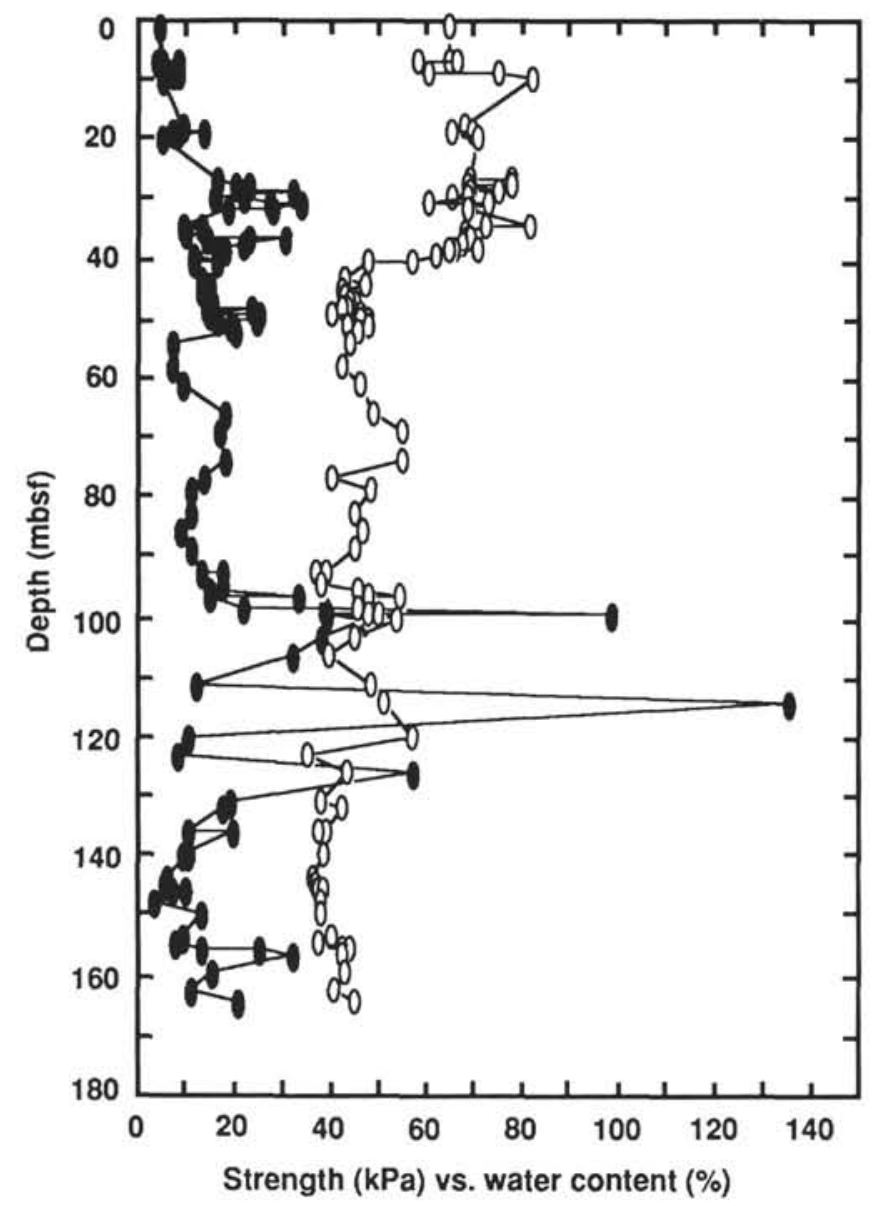

Figure 7. Plot of vane shear strength (filled oval) vs. water content (open oval) for Site 751 showing correlation between increased water and increased strength at specific depths downhole.

very closely and disassociate into crystallites, which close off even more pore space (e.g., Plates 4 and 5); nannofossils contribute most of the $\mathrm{CaCO}_{3}$ in these sediments.

\section{Accumulation Rates and Hiatuses}

Regions of high productivity, associated with upwelling, produce large fluxes of phytoplankton (diatoms and coccolithophorids) and zooplankton (foraminifers and radiolarians). Productivity variations, linked to climatic and oceanographic factors, and dissolution or erosional effects are largely responsible for causing changes in microfossil assemblages.

Carbonate productivity fluctuations are difficult to identify in the geologic record. Dean and Gardner (1986) note that large fluctuations in carbonate content $(>30 \%-40 \%)$ are not easily explained by productivity alone; but rather, must include some degree of dissolution or erosion because of the magnitude of the observed change. The goal of identifying productivity fluctuations is further complicated by the changing importance of individual processes, such as dissolution, erosion, dilution by other sedimentary components, and changirig degree of preservation, in creating the observed sequence.

Dissolution events are most evident in regions exhibiting high diversity gradients, such as the Polar Front and Subtropical Convergence. Dissolution can be evaluated using such parameters as increased numbers of benthic foraminifers,

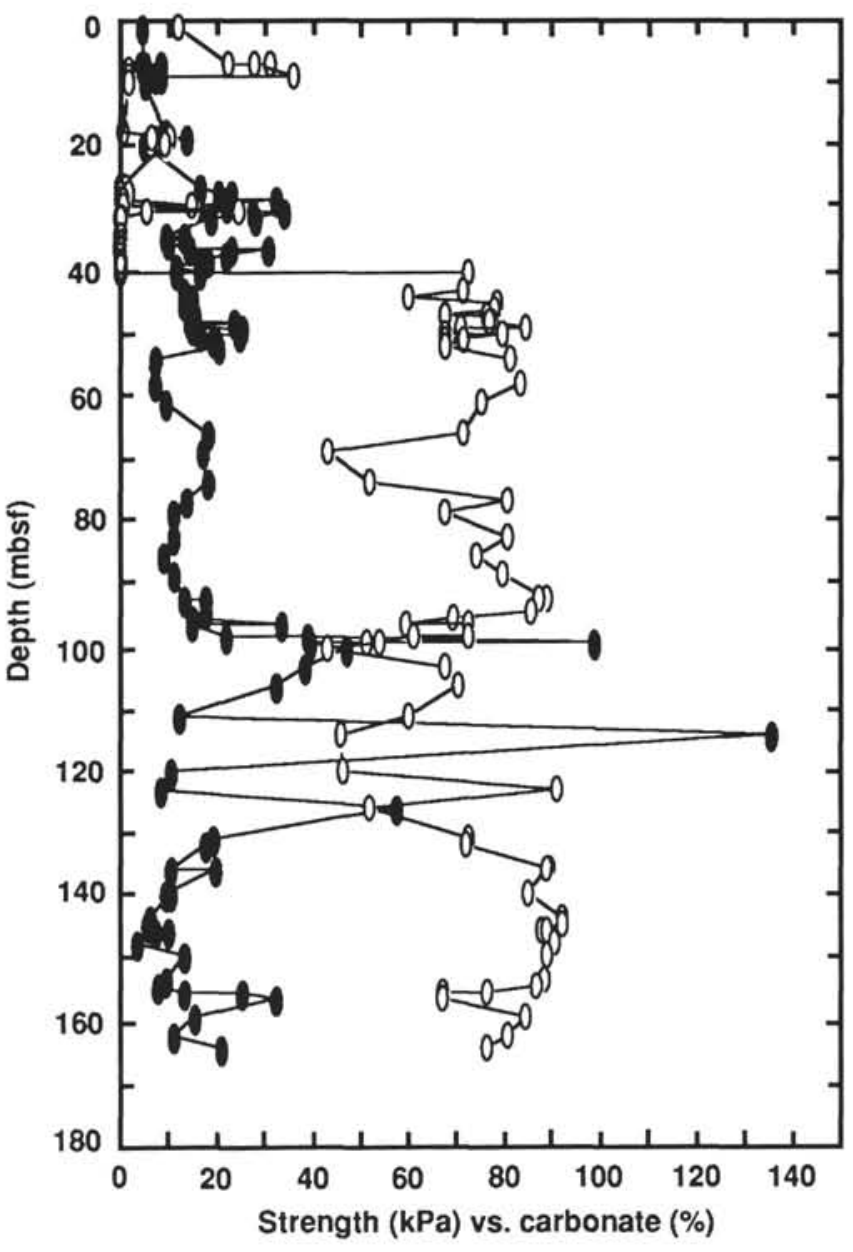

Figure 8. Plot of vane shear strength (filled oval) vs. carbonate content (open oval) for Site 751 showing correlation between decreased carbonate content and increased strength at specific depths downhole.

increased fragmentation of tests, and changes in radiolarian abundance, contrasted with fluctuations in calcium carbonate percentage (Williams et al., 1985a, 1985b).

\section{Accumulation Rates}

Absolute accumulation rates (flux rates) can be determined for any component of the sediment by multiplying the drybulk density and linear sedimentation rate and the weight percent of the component in the sediment. Clemens et al. (1987) presented equations for estimating dry-bulk density from carbonate content that give similar results to the equations presented in this paper (their data came from five Eltanin piston cores in the southeast Indian Ocean north of Kerguelen Island). They cautioned that productivity differences between water masses may bias interpretations of paleowater mass movement from relative microfossil abundance data, and consequently they recommended using absolute accumulation rates derived from dry-bulk density values to eliminate ratedependent effects.

We calculated absolute accumulation rates by multiplying the percentage of each sedimentary constituent by the drybulk density (shipboard measurement) and the linear sedimentation rate derived from shipboard age assignments (note that our results are contingent on future revision of biostratigraphic determinations). We determined calcium carbonate accumulation rates using shore-based laboratory data of car- 


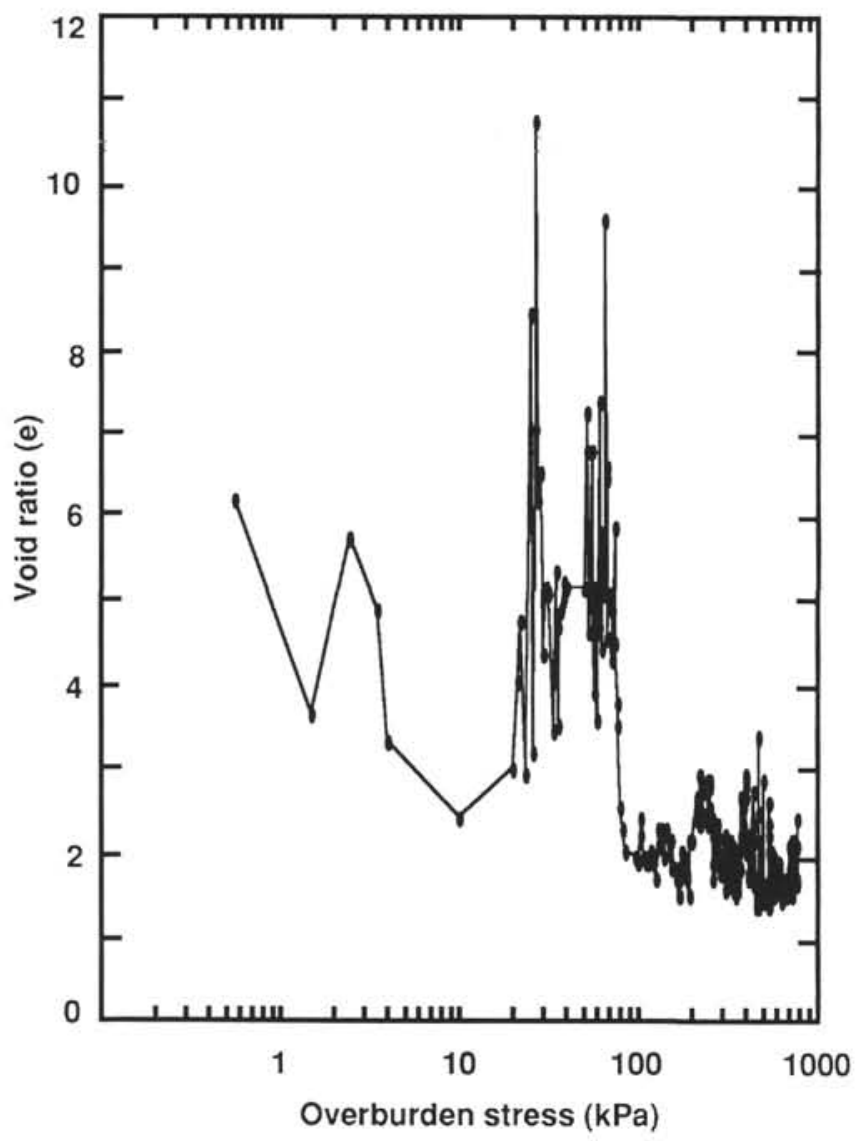

Figure 9. Plot of void ratio vs. overburden stress for Site 751. Note the sharp decrease in void ratio below $75 \mathrm{kPa}$ indicating the boundary between Units I and II at this site.

bonate content (Fig. 11A), and noncarbonate accumulation rates by assuming a two-component system (i.e., $100 \%-w t \%$ $\mathrm{CaCO}_{3}=\mathrm{wt} \% \mathrm{SiO}_{2}$ ) (Fig. 11B). Although this assumption includes ice-rafted and aeolian components of the total flux, generally $<10 \%$ of Site 751 sediments, it does give a good first-order approximation of changing siliceous accumulation. This approximate siliceous accumulation is compared with rates determined using data from chemical analyses of wt $\%$ $\mathrm{SiO}_{2}$ provided by D. DeMaster (North Carolina State University). The chemical data shows lower wt $\% \mathrm{SiO}_{2}$ than would be expected; however, if we include the wt $\%$ water associated with biogenic opal $(6 \%-15 \%$, or a mean value of $10 \%)$, we can account for most of the difference between the calculated and analyzed values. Ice-rafted debris (IRD) accumulation rates were determined by Breza (this volume) on a grain $/ \mathrm{cm}^{2} / \mathrm{k} . \mathrm{y}$. basis. We use IRD flux data from Breza's study (using samples located adjacent to our physical properties samples), to compare the calculated carbonate and noncarbonate accumulation rates derived from our study with IRD peaks (Figs. $12 \mathrm{~A}$ and 12B). The highest IRD flux was observed between $\sim 25$ and 40 mbsf and at 7-10 mbsf. The interval from 15-20 mbsf shows minimal IRD accumulation, yet shows $5-7 \mathrm{~g} / \mathrm{m}^{2} /$ k.y. accumulation of noncarbonate material; thus providing a rough estimate of the average biosiliceous flux during the Pliocene at Site 751. This estimate agrees well with the siliceous accumulation rate of $10.0 \mathrm{~g} / \mathrm{m}^{2} / \mathrm{k}$.y. reported for the central Circumpolar Ocean by Lisitzin (1985), which was determined for the time interval from 0 to 0.7 m.y. (Brunhes Chron). The rate of noncarbonate accumulation calculated for

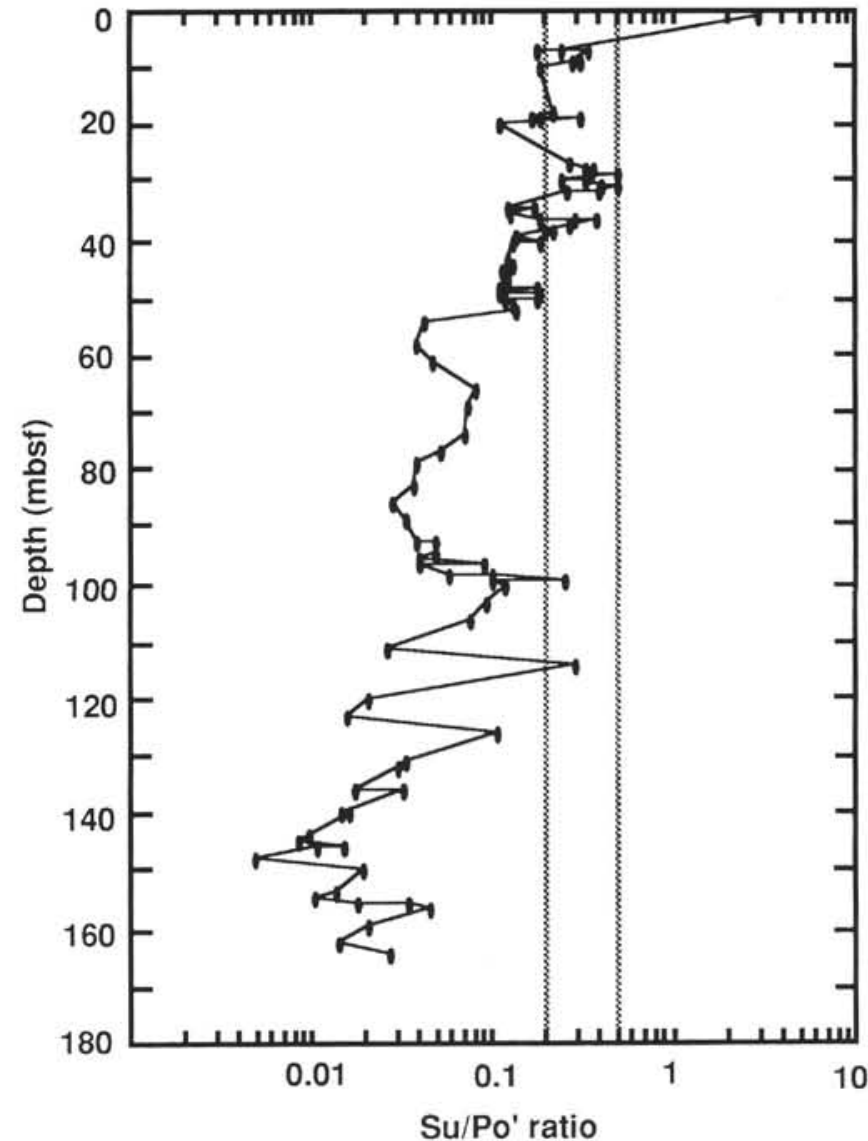

Figure 10. Plot showing the ratio of undrained shear strength/overburden stress vs. depth for Site 751. Values of this ratio above 0.5 indicate apparent overconsolidation; values below 0.2 indicate apparent underconsolidation; and values between 0.2 and 0.5 indicate normally consolidated sediment.

sediment in the upper few meters of Site 751 is equal to $\sim 1.5$ $\mathrm{g} / \mathrm{m}^{2} / \mathrm{k} . \mathrm{y}$. (during the Pleistocene).

The accumulation of biogenic silica is fairly constant below $40.1 \mathrm{mbsf}$, averaging approximately $4.0 \mathrm{~g} / \mathrm{m}^{2} / \mathrm{k} . \mathrm{y}$. throughout lithologic Unit II. Peaks in siliceous accumulation, associated with low carbonate accumulation rates, occur at three distinct intervals in Unit II (Fig. 11B). These intervals are: (1) $\sim 60-76$ mbsf (Subunit G-IIc); (2) 95-115 mbsf (Subunits G-IIf, G-IIg, and G-IIh); and (3) 125-135 mbsf (Subunits G-IIj and G-IIk). The interval between 95 and 115 mbsf shows extreme variability in carbonate accumulation rates, indicating large variations in productivity and/or erosion. Carbonate accumulation drops dramatically at $\sim 109$ mbsf and slightly above 115 mbsf. The decrease at $\sim 109$ mbsf is marked by a $5 \%$ porosity increase and sharply reduced density values. The decrease at $\sim 115$ mbsf is clearly shown by increased shear strength values, indicating enhanced silica preservation combined with erosion and/or dissolution from corrosive water masses flowing over the site.

\section{Hiatuses}

Four hiatuses in the sedimentary record were recognized on the basis of shipboard biostratigraphy: (1) 1.9-2.2 Ma, $6.3 \mathrm{mbsf}$; (2) 4.7-5.3 Ma, $40.1 \mathrm{mbsf}$; (3) 6.2-9.5 Ma, $54.5 \mathrm{mbsf}$; and (4) 12.1-14.8 Ma, 109.5 mbsf. The updated diatom biostratigraphy of Harwood and Maruyama (this volume) has been incorporated into this study to provide improved age control, and additional 


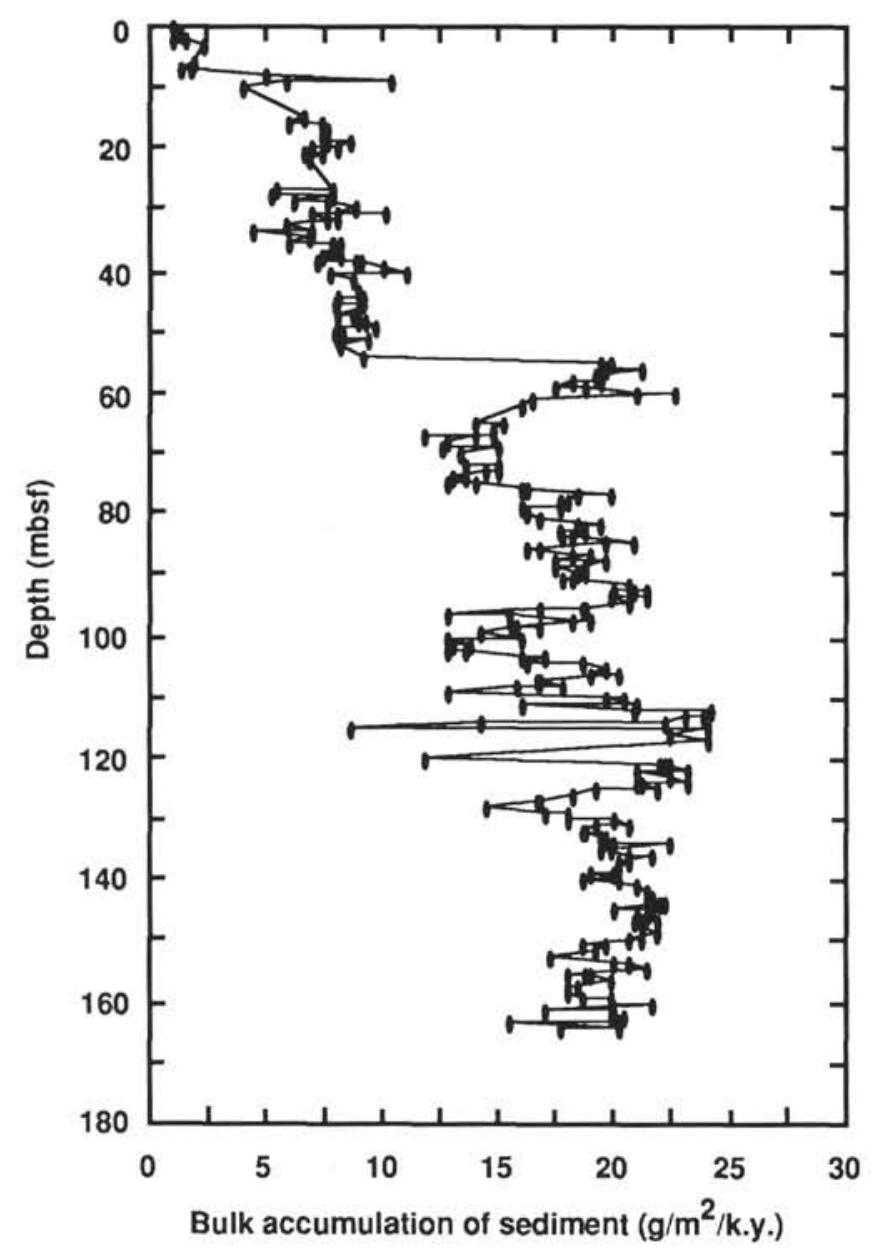

B

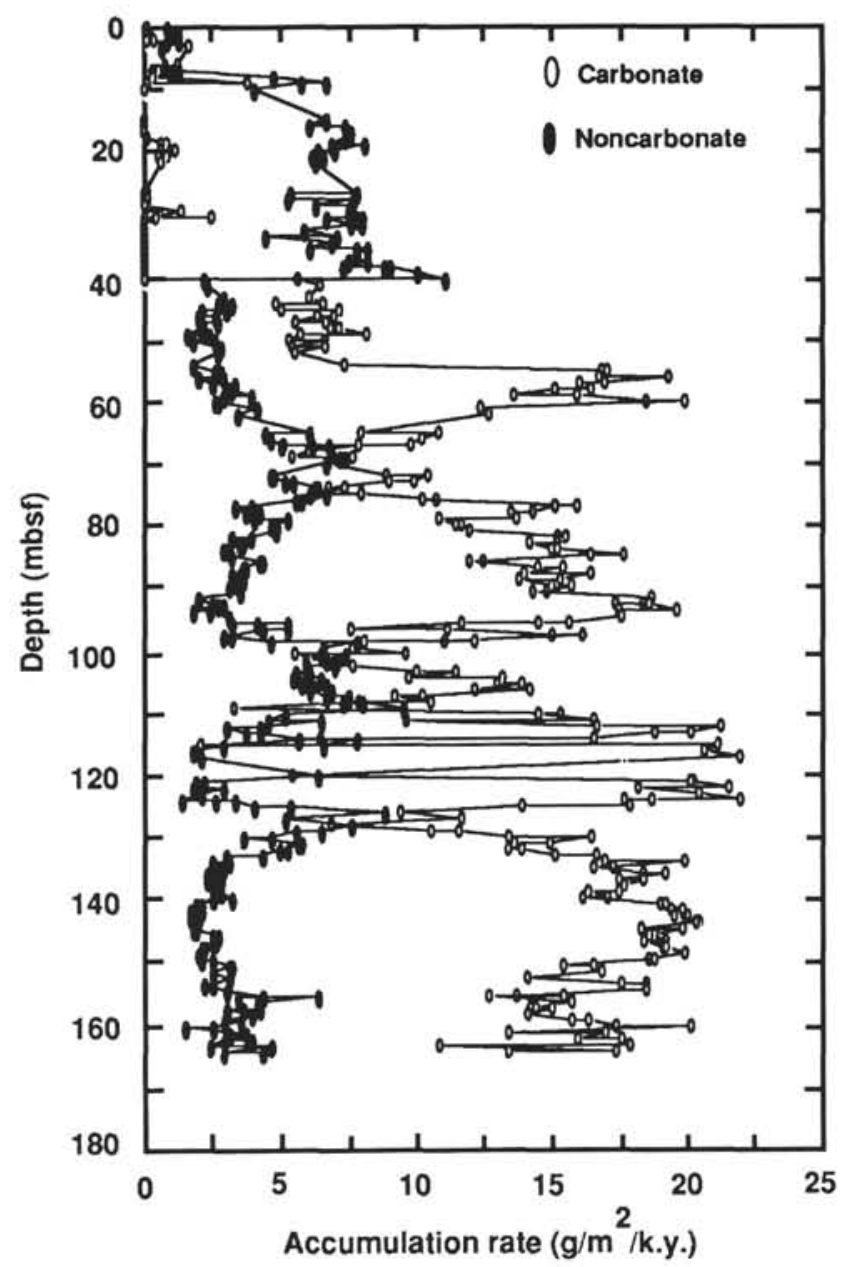

Figure 11. A. Plot illustrating the bulk accumulation of sediment vs. depth for Site 751 . The increase in accumulation rate from $\sim 10$ to $\sim 20$ near 55 mbsf is associated with a hiatus at $\sim 8.8 \mathrm{Ma}$. B. Plot illustrating the absolute accumulation of carbonate and noncarbonate (assumed to be opal) sediment vs. depth for Site 751. Increases in noncarbonate accumulation often are associated with large decreases in carbonate accumulation rates. Carbonate accumulation above 40.1 mbsf is severely restricted.

hiatuses have been recognized (see Table 3). We have evaluated the geotechnical stratigraphy at Site 751 to determine the effect of each hiatus on physical properties changes (e.g., was the hiatus erosional or nondepositional). Of the hiatuses identified during the cruise, the lower two appear to be erosional, with increased bulk density and decreased porosity directly leading up to the unconformity, with reversed trends above. These observations may also reflect increased productivity or preservation of siliceous microfossils during episodes of increased carbonate dissolution. The upper two events are linked to sharp lithologic discontinuities, which makes them difficult to identify conclusively as nondepositional or erosional. However, the discontinuity at 40.1 mbsf, associated with a $2.5-\mathrm{m} . \mathrm{y}$. hiatus (8.4-5.9 Ma) is most likely an erosional event, marking the passage of the Polar Front across the Site 751 location and intensification of the ACC system.

\section{Highlights of Geotechnical Stratigraphic Analysis}

The following are the most significant findings of our geotechnical stratigraphic analysis:

1. Subunit G-IIi (Figs. 13 and 14) is identified by a narrow zone of fairly constant, high bulk-density, low porosity, and high carbonate values, associated with low shear strengths. Subunit G-IIj ( $\sim 125-128 \mathrm{mbsf})$ is associated with a gradual $10 \%$ porosity decrease, an increase in bulk density, and low average carbonate content. The base of Subunit G-IIj $(\sim 128$ mbsf) is marked by a sharp decline in carbonate content, reversals in density trends, and a porosity peak. Harwood and Maruyama (this volume) suggest a hiatus near 128-131 mbsf (see Table 3). This event may be represented by small reversals in index properties and a large change in carbonate content at $\sim 131$ mbsf. Below Subunit G-IIj, there are reduced amplitude changes $(5 \%-7 \%)$ in porosity and wet- and dry-bulk density for the remainder of the section.

2. Subunit G-IIh (Table 2 and Figs. 13 and 14) is particularly interesting since it exhibits large changes in carbonate contents and index properties over a $\sim 10$-m interval of Hole $751 \mathrm{~A}$. The significant changes in porosity, bulk density, and grain density within narrow zones are superimposed on an overall, gradual decrease in carbonate content from the base of this unit to the middle of Subunit G-IIf. The high amplitude fluctuations of carbonate content allow us to compare the effects of nondeposition, dilution of the carbonate flux by silica, or erosion during the early to middle Miocene. Each sharp carbonate decrease is marked by a 
A

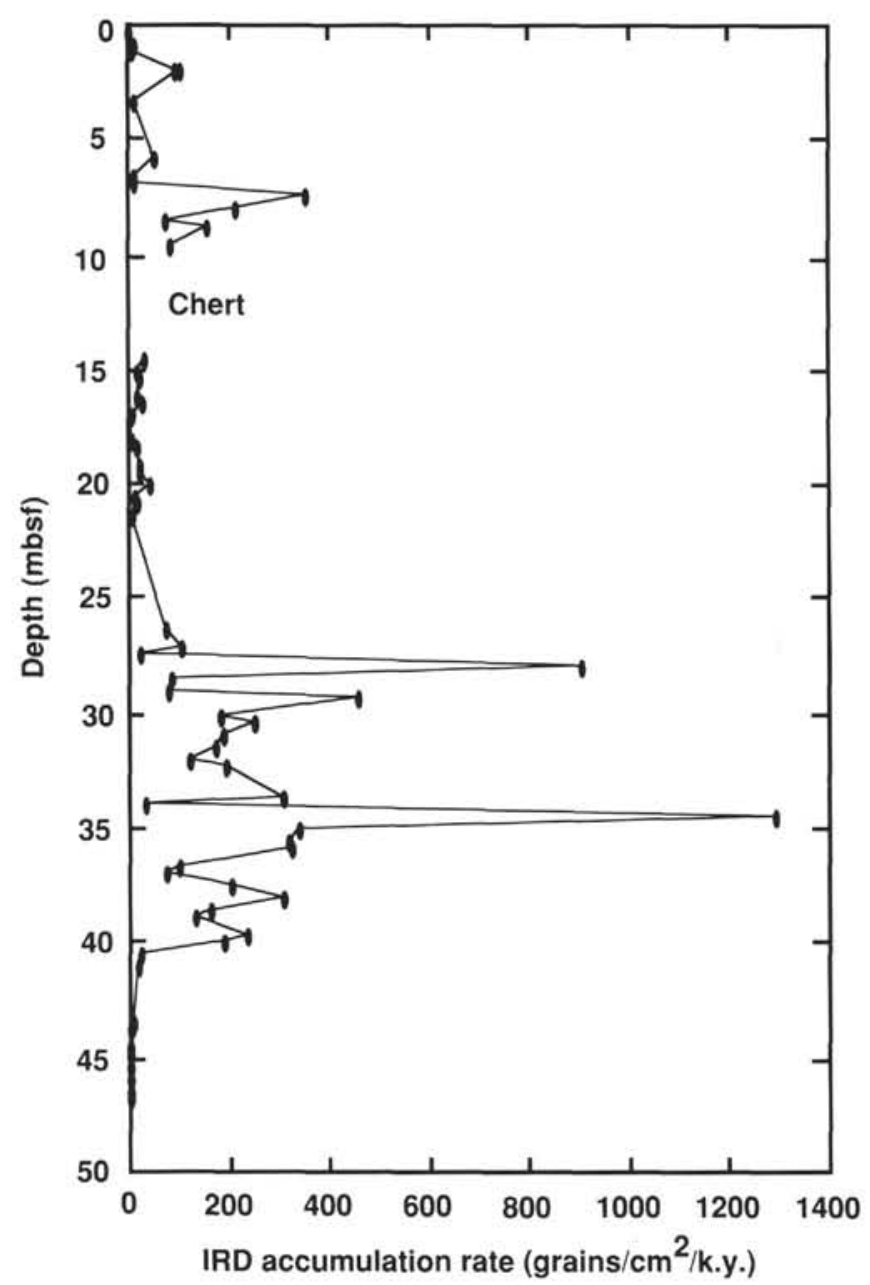

B

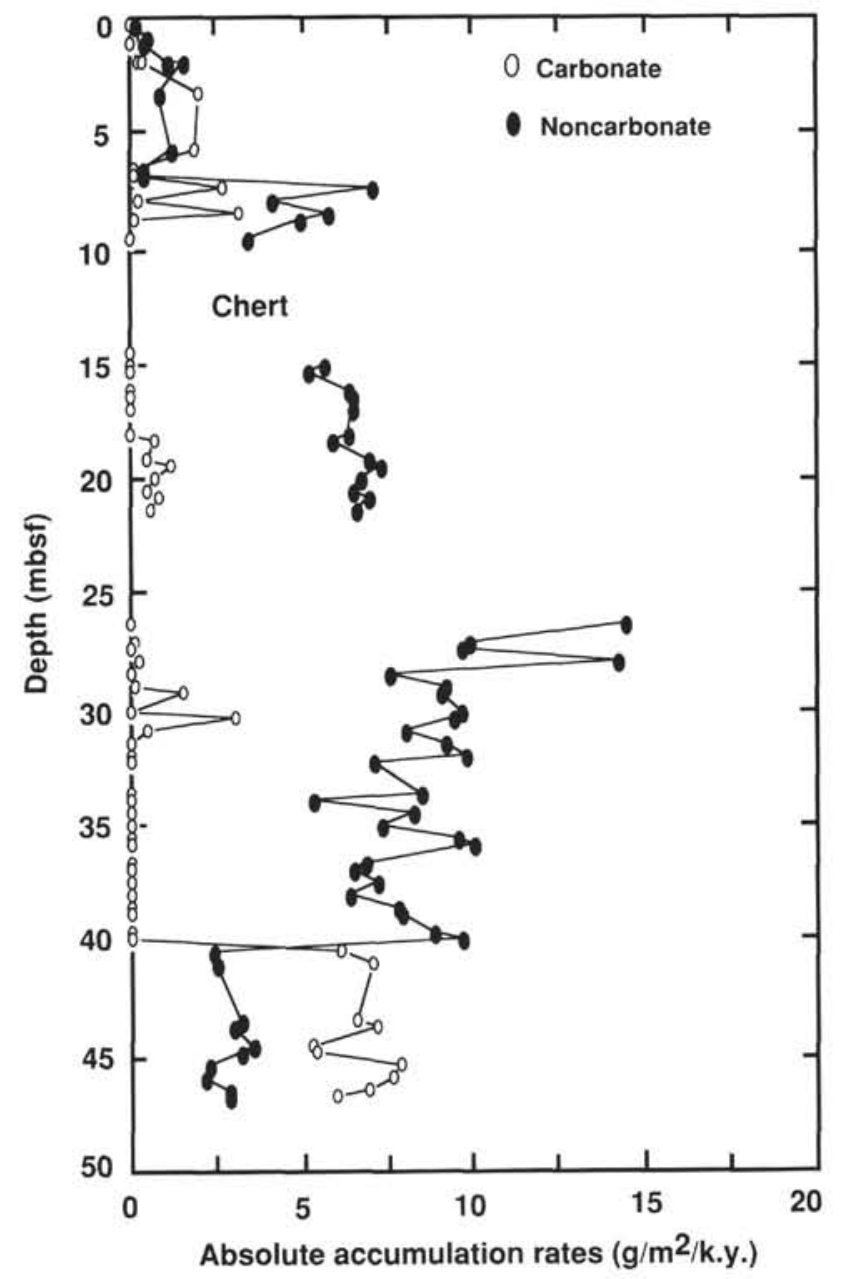

Figure 12. A. Plot illustrating the accumulation of ice-rafted debris (IRD) vs. depth (modified from Breza, this volume) for Site 751. Major increases in IRD flux occur between 40-27 mbsf and 6-10 mbsf. B. Plot illustrating the absolute accumulation of carbonate and noncarbonate sediment vs. depth for Site 751. Noncarbonate accumulation rates include biogenic silica and IRD accumulation.

sharp increase in porosity, generally reflecting increased accumulation of biogenic silica within that interval.

3. The top of Subunit G-IIh ( 109.9 mbsf; Figs. 13 and 14) is marked by a sharp decrease in carbonate; porosity shows a $10 \%$ increase, and bulk density decreases sharply at the boundary (before gradually increasing within Subunit G-IIg). Grain density values decrease from 2.76 to $2.35 \mathrm{~g} / \mathrm{cm}^{3}$ across this boundary. A hiatus from $\sim 13.3$ to $14.1 \mathrm{Ma}$ and an increase in shear strength are also associated with these changes.

4. Subunits G-IIg, G-IIf, and G-IIe are separated from each other by sharp trend reversals and inflections in index properties and carbonate content over the interval from $\sim 109$ to 90.0 mbsf (Figs. 13 and 14). These shifts are also seen in changes of sediment bulk accumulation rates.

5. Subunit G-IId and G-IIb exhibit similar physical properties and carbonate contents (Fig. 15). The boundary between Subunits G-IIb and G-IIa is marked by a drastic change in bulk sediment accumulation rate, a $20 \%$ decrease in carbonate content and inflections in index property trends. Subunit G-IIb is underconsolidated relative to Subunit G-IIa; probably as a result of the increased accumulation of low permeability nannofossil ooze and the existence of a possible erosional hiatus (at $\sim 8.8 \mathrm{Ma}$ ) across this boundary.
Table 3. Ages of hiatuses at Site 751.

\begin{tabular}{|c|c|c|c|}
\hline Age (Ma) & Geologic age & $\begin{array}{l}\text { Depth } \\
\text { (mbsf) }\end{array}$ & Evidence \\
\hline $0.8-1.6$ & Pleistocene & $1.1-1.3$ & $\mathrm{D}, \mathrm{M}, \mathrm{L}_{\mathrm{ss}}, \mathrm{L}_{\mathrm{c}}, \mathrm{P}, \mathrm{C}$ \\
\hline $1.8-3.0$ & $\begin{array}{l}\text { Pleistocene/ } \\
\text { late Pliocene }\end{array}$ & 6.3 & $\mathrm{D}, \mathrm{M}, \mathrm{L}_{\mathrm{ss}}, \mathrm{L}_{\mathrm{c}}, \mathrm{P}, \mathrm{C}, \mathrm{R}$ \\
\hline $4.1-4.3 ?$ & early Pliocene & 25.9 & $, L_{c}, P, C$ \\
\hline $4.4-5.6$ & $\begin{array}{l}\text { early Pliocene/ } \\
\text { late Miocene }\end{array}$ & 35.4 & $\mathrm{D}, \mathrm{M}, \mathrm{L}_{\mathrm{ss}}, \mathrm{L}_{\mathrm{c}}, \mathrm{P}, \mathrm{C}$ \\
\hline $5.9-8.4$ & late Miocene & 40.1 & $\begin{array}{l}\mathrm{D}, \mathrm{M}, \mathrm{L}_{\mathrm{ss}}, \mathrm{L}_{\mathrm{c}}, \mathrm{P}, \mathrm{C}, \\
\mathrm{R} \text {, }\end{array}$ \\
\hline$\sim 8.8$ ? & late Miocene & 54.5 & $\mathrm{~L}_{\mathrm{ss}}, \mathrm{L}_{\mathrm{c}}, \mathrm{P}, \mathrm{C}, \mathrm{F}$ \\
\hline$\sim 10 ?$ & late Miocene & $\sim 75$ & $\mathrm{M}, \mathrm{L}_{\mathrm{ss}}, \mathrm{L}_{\mathrm{c}}, \mathrm{P}, \mathrm{C}$ \\
\hline $12.1-12.8$ & middle Miocene & $\sim 104.5$ & $\mathrm{D}, \mathrm{M}, \mathrm{L}_{\mathrm{ss}}, \mathrm{L}_{\mathrm{c}}, \mathrm{P}, \mathrm{C}$ \\
\hline $13.3-14.1$ & middle Miocene & 109.5 & $\mathrm{M}, \mathrm{L}_{\mathrm{ss}}, \mathrm{L}_{\mathrm{c}}, \mathrm{P}, \mathrm{C}, \mathrm{R}$ \\
\hline$\sim 14.2$ & middle Miocene & $\sim 115$ & $L_{s s}, L_{c}, P, C$ \\
\hline$\sim 14.5$ & middle Miocene & $\sim 120$ & $\mathrm{~L}_{\mathrm{ss}}, \mathrm{L}_{\mathrm{c}}, \mathrm{P}, \mathrm{C}$ \\
\hline $15.1-16.5$ & $\begin{array}{l}\text { middle/early } \\
\text { Miocene }\end{array}$ & $129-131$ & $\mathrm{D}, \mathrm{M}, \mathrm{L}_{\mathrm{ss}}, \mathrm{L}_{\mathrm{c}}, \mathrm{P}, \mathrm{C}$ \\
\hline
\end{tabular}

Notes: Evidence for identification of hiatuses at Site 751 is as follows: $\mathrm{D}=$ diatom biostratigraphy (from Harwood and Maruyama, this volume) $\mathrm{M}=$ magnetostratigraphy; $\mathrm{L}_{\mathrm{ss}}=$ lithology (as determined from smear slide analysis); $\mathrm{L}_{\mathrm{c}}=$ lithology (as determined by visual core description); $\mathrm{P}=$ physical properties data; $\mathrm{C}=$ calcium carbonate content; $\mathrm{F}$ = planktonic foraminifer biostratigraphy; and $\mathbf{R}=$ radiolarian biostratigraphy. 


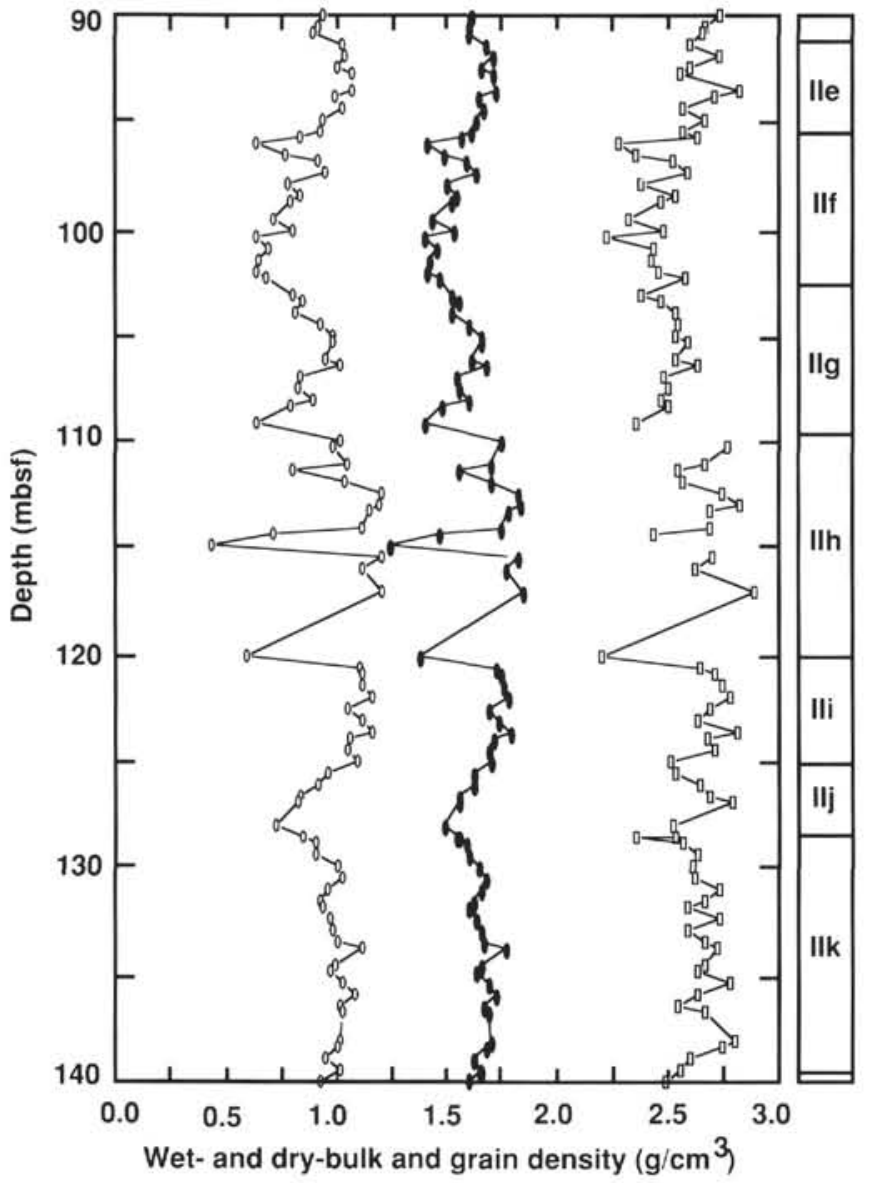

Figure 13. Plot of wet-bulk (filled oval), dry-bulk (open oval), and grain density (open rectangle) vs. depth for Site 751 ; for the depth interval between 90 and 140 mbsf. Geotechnical subunits are also shown.

Wei and Wise (this volume) present relative abundance data for Reticulofenestra perplexa, which represents the cold water end-member of Miocene calcareous nannofossil assemblages. Positive shifts in the relative abundance of this species indicates decreasing water temperatures, whereas decreasing relative abundance generally suggests warmer temperatures (see Wei and Wise, this volume). The relative abundance variations of $R$. perplexa help to illustrate the differences between Subunits G-IIf and G-IIa by graphically illustrating changes in calcareous microfossil assemblages from $\sim 40$ to 100 mbsf (Fig. 15). Subunits G-IIe and G-IId, and Subunit G-IIb represent periods of high $R$. perplexa abundance; and therefore decreased water temperatures. The decline in relative abundance of $R$. perplexa in Subunit G-IIc is accompanied by generally increased noncarbonate (e.g., siliceous) accumulation from $\sim 80$ to $\sim 60$ mbsf (Fig. 16), and decreased carbonate accumulation. Colder water temperatures could be responsible for decreased abundances of $R$. perplexa in parts of this interval because of the environmental stress placed on the species by frigid Antarctic surface waters (Wise, personal communication). Subunit G-IIa is marked by decreased abundances of $R$. perplexa and decreased accumulation rates before the change to lithologic Unit I.

We interpret the variations in physical properties observed at Site 751 to be the result of: (1) fluctuations in surface-water productivity that variably favored production of siliceous or calcareous microplankton, and (2) variations in the nature of the water masses at the site that selectively favored preserva-

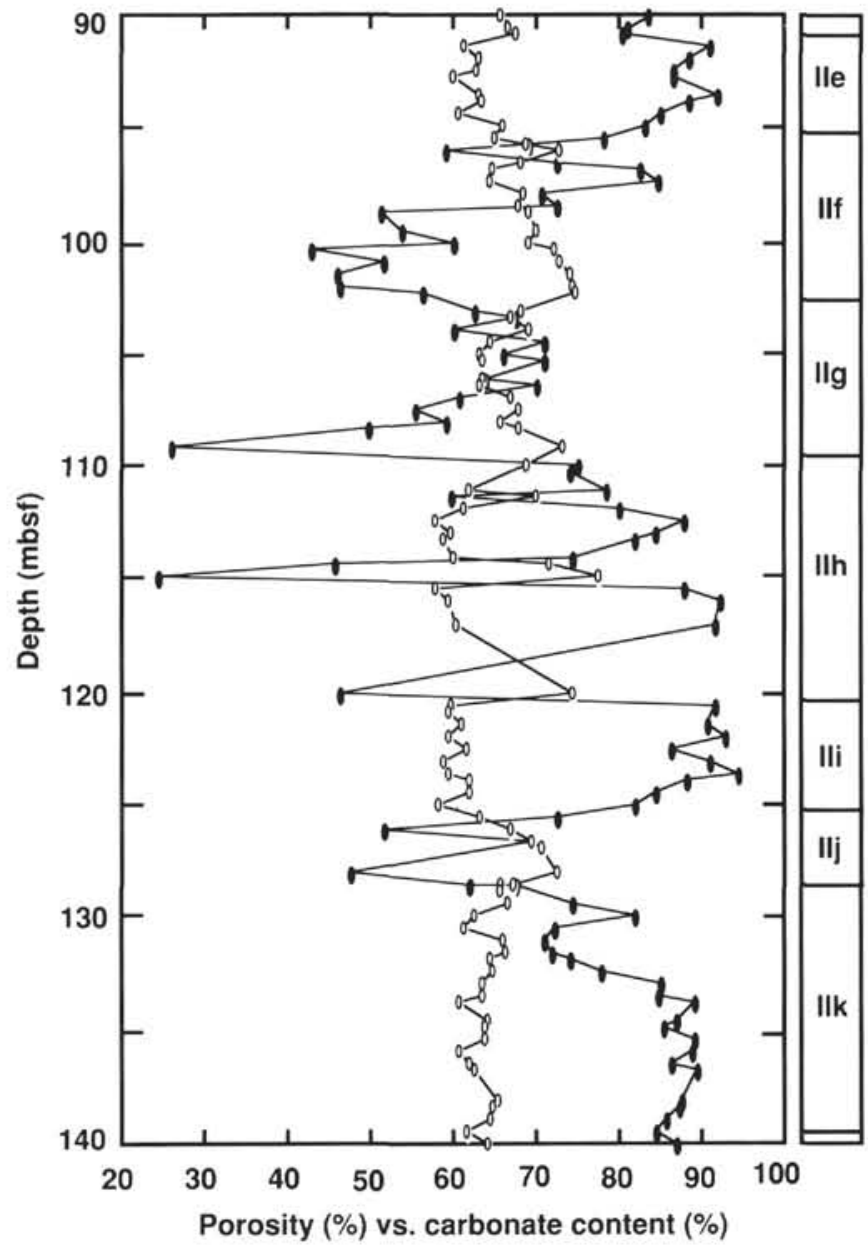

Figure 14. Plot of porosity (open oval) and carbonate content (filled oval) vs. depth for Site 751; for the depth interval between 90 and 140 mbsf. Geotechnical subunits are also shown.

tion of the siliceous or calcareous microfossils. These factors are directly related to oceanographic conditions controlled by the position of the Polar Front and the intensity of the Antarctic Circumpolar Current system. The Kerguelen Plateau would probably have been most influenced by Antarctic intermediate water masses than by bottom water because of its elevation above the deep basins of the southern Indian Ocean. The site was certainly above the regional CCD during the Neogene; however, dissolution caused by corrosive water masses appears to have been an important influence on deposition.

\section{CONCLUSIONS}

Site 751 records the northward migration and strengthening of the Antarctic Polar Front during the late Neogene. At $\sim 110$ mbsf (13.3-14.1 Ma) there is an erosional hiatus that could represent northward and southward pulses of the Polar Front or increased erosion by the Antarctic Circumpolar Current system. An erosional hiatus at $54.4 \mathrm{mbsf}(\sim 8.8 \mathrm{Ma})$ may represent another expansion of the Polar Front. Although this event is not observed in the revised diatom biostratigraphy, it is accompanied by large changes in accumulation rates and inflections in all measured physical properties. The abrupt change from calcareous to siliceous sediments at $40.1 \mathrm{mbsf}$ (the lithologic Unit $\mathrm{I} / \mathrm{II}$ boundary) is marked by a hiatus of $\sim 2.5$ m.y. (8.4-5.9 Ma; late Miocene, near Miocene/Pliocene 


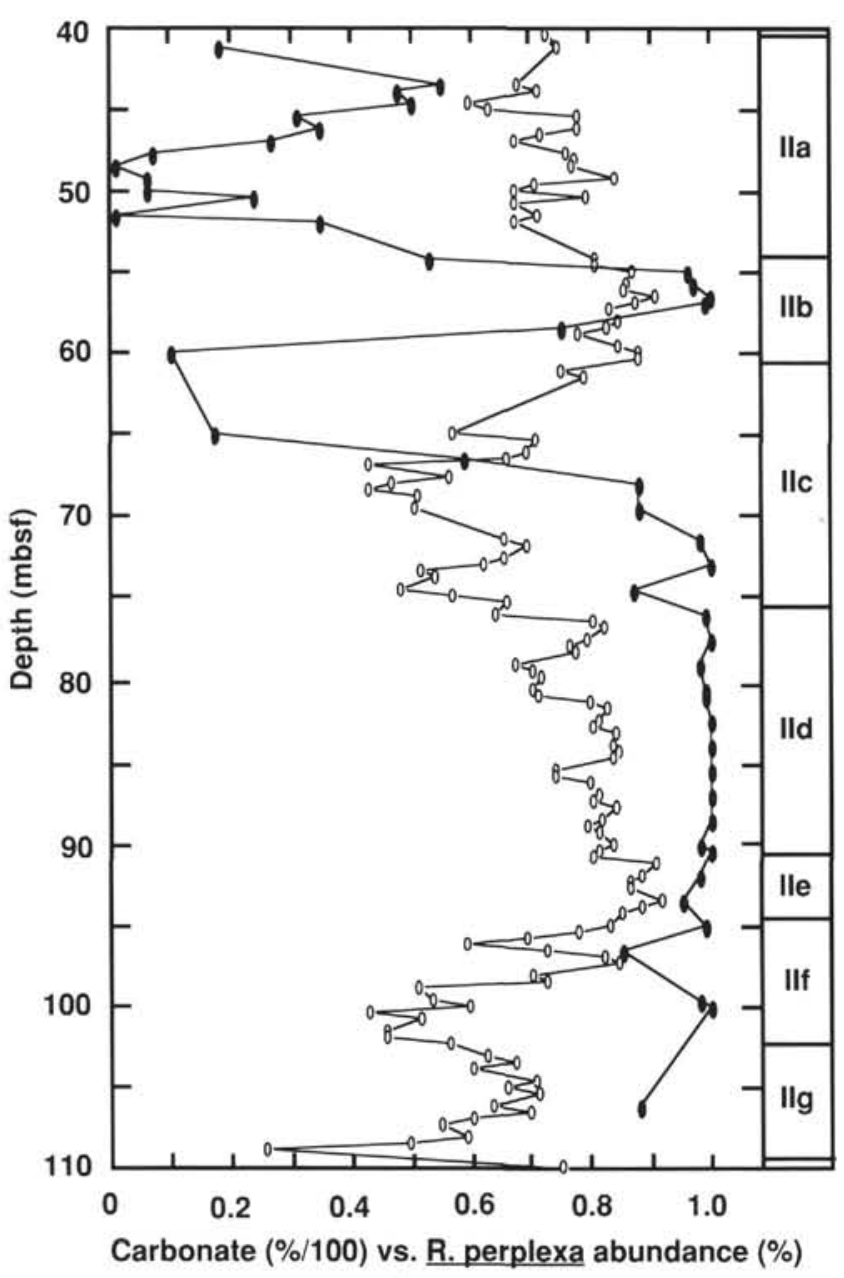

Figure 15. Plot of decimal percent carbonate content (open oval) and percent relative abundance of calcareous nannofossil species Reticulofenestra perplexa (filled oval) vs. depth for Site 751 ; for the depth interval between 40 and 110 mbsf (Relative abundance data for $R$. perplexa taken from Wei and Wise, this volume). Geotechnical subunits are also shown.

boundary). This is earlier than the general increase in Southern Ocean biogenic silica deposition at $\sim 5 \mathrm{Ma}$ correlated with a $300 \mathrm{~km}$ northward expansion of the Polar Front (Brewster, 1980).

The early and middle Miocene sequence at Site 751 is characterized by high, relatively constant, carbonate accumulation with variable preservation in specific zones. The large changes in percent calcium carbonate and the presence of two significant hiatuses within this interval (at $\sim 109 \mathrm{mbsf}$ and $\sim 131 \mathrm{mbsf}$ ) argues for erosion by Circumpolar Deep Water or corrosive intermediate waters in response to the strengthening of circumpolar circulation patterns. It is difficult to rule out carbonate productivity changes as being responsible for large changes in carbonate content, but we feel that other mechanisms (e.g., erosion and dissolution) are more likely a result of the magnitude and apparent rapidity of many of the shifts. The presence of subtropical faunas, and the high percentage of carbonate observed in early to middle Miocene samples, indicates that the Polar Front was not established until the late Miocene over the Kerguelen Plateau (as a high gradient oceanic barrier). The accumulation of siliceous microfossils was nearly constant throughout this period, although some

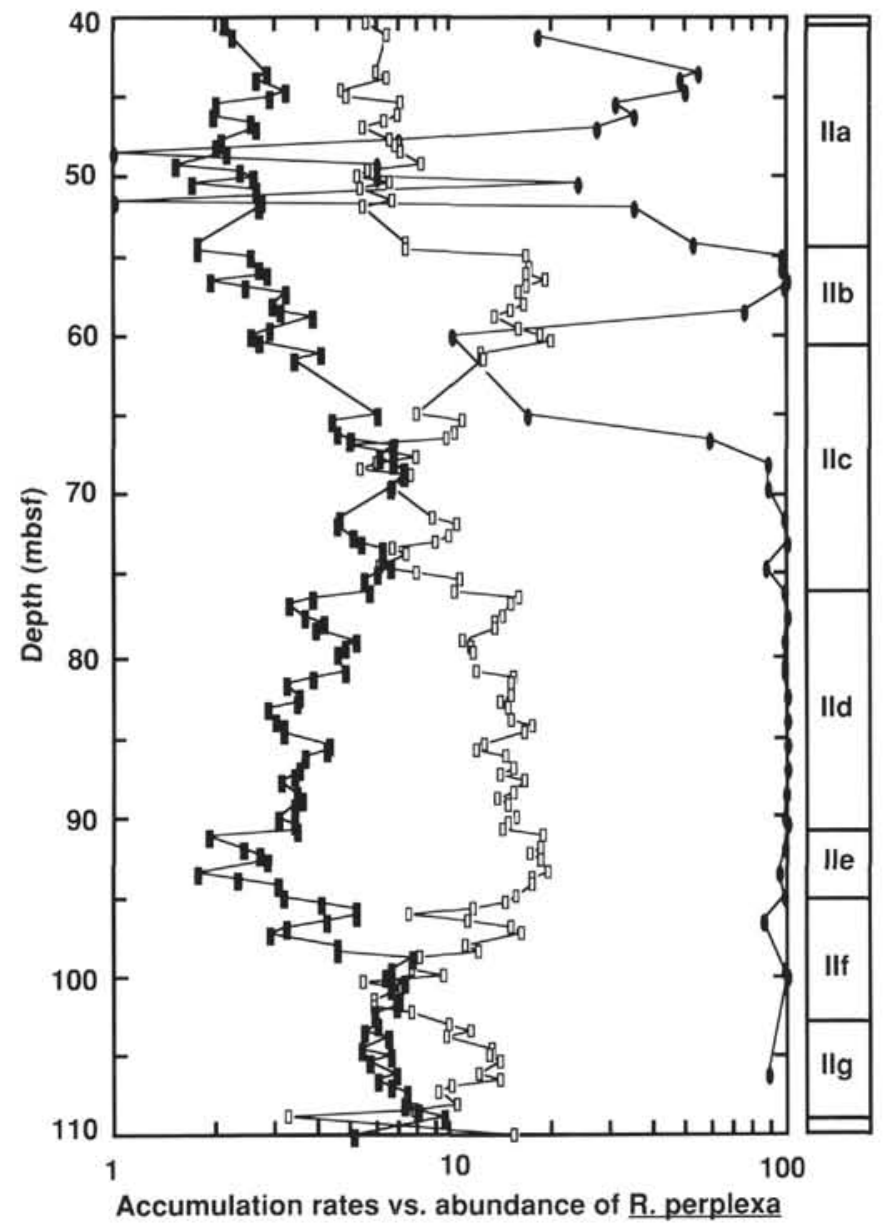

Figure 16. Logarithmic plot of absolute accumulation rates of carbonate (open rectangle) and noncarbonate (filled rectangle) in $\mathrm{g} / \mathrm{m}^{2} / \mathrm{k} . \mathrm{y}$. and percent relative abundance of $R$. perplexa (filled oval) vs. depth for Site 751; for the depth interval between 40 and 110 mbsf. Geotechnical subunits are also shown.

temporally restricted increases in siliceous accumulation are noted in association with carbonate reductions. Microfabric investigations were used to aid in the interpretation of dissolution events when possible.

The major change in facies from dominantly nannofossil ooze to dominantly siliceous ooze at Site 751 at $40.1 \mathrm{mbsf}$ is interpreted to represent the establishment of a high-gradient polar front north of this site in the latest Miocene. The decreased rates of carbonate accumulation and increased siliceous accumulation across this boundary reflect the cooling of the surface waters and strengthening of zonal circulation patterns over the plateau. A further decrease in bulk accumulation in the late Pliocene corresponds with a second northward movement of the Polar Front toward Kerguelen Island.

Fluctuations in physical properties of a high-latitude pelagic sedimentary sequence primarily records shifts in the dominance of siliceous and calcareous microfossil assemblages with depth. These dominance shifts correspond in turn to oceanographic and climatic changes controlled by both regional and global forcing mechanisms. The northward movement of the Antarctic Polar Front and its associated water masses, in response to deteriorating climatic conditions across the Kerguelen Plateau during the late Miocene and early Pliocene, is illustrated on the seafloor by a decreased 
diversity of microfossil assemblages and an increased dominance of siliceous sedimentation.

The evolution and subsequent history of zonal sedimentation patterns on the ocean floor of the southern Indian Ocean is assumed to reflect (1) the strengthening/weakening of the Antarctic Circumpolar Current system; (2) the expansion or contraction of the geographic area influenced by Antarctic/ Subantarctic surface waters and their associated faunas; (3) the changing production of intermediate and deep waters over time; and (4) shifts in the distribution and volume of ice on Antarctica. Site 751 in the Raggatt Basin preserves the record of these changes during the Neogene.

\section{ACKNOWLEDGMENTS}

We deeply appreciate the assistance of Lisa Donaghe of the Texas A\&M Electron Microscopy Center in conducting our SEM analyses. The manuscript was greatly improved thanks to discussions with Jack Baldauf (ODP) and reviews by B. Charlotte Schreiber and R. H. Wilkens. This project received USSAC funding under Grant No. 20241.

\section{REFERENCES}

Arthur, M. A., von Huene, R., and Adelseck, C. G., Jr., 1980. Sedimentary evolution of the Japan fore-arc region off northern Honshu. In von Huene, R., Nasu, N., et al., Init. Repts. DSDP, 56, 57 (Pt. 2): Washington (U.S. Govt. Printing Office), 521-568.

Bachman, R. T., 1984. Intratest porosity in foraminifera. J. Sediment. Petrol., 54:257-262.

Barker, P. F., Kennett, J. P., et al., 1988. Proc. ODP, Init. Repts., 113: College Station, TX (Ocean Drilling Program).

1990. Proc. ODP, Sci. Results, 113: College Station, TX (Ocean Drilling Program).

Barron, J. A., and Baldauf, J. G., 1989. Tertiary cooling steps and paleoproductivity as reflected by diatoms and biosiliceous sediments. In Berger, W. H., Smetacek, V. S., and Wefer, G. (Eds.), Productivity of the Ocean: Present and Past. New York (WileyInterscience), 341-354.

Barron, J. A., Larsen, B., et al., 1989. Proc. ODP, Init. Repts., 119: College Station, TX (Ocean Drilling Program).

Bennett, R. H., Bryant, W. R., and Keller, G. H., 1977. Clay fabric and geotechnical properties of selected submarine sediment cores from the Mississippi Delta. NOAA Prof. Pap., No. 9.

Bennett, R. H., Fischer, K. M., Lavoie, D. L., Bryant, W. R., and Rezak, R., 1989. Phorometry and fabric of marine clay and carbonate sediments: determinants of permeability. Mar. Geol., $89: 127-152$.

Bohrmann, G., and Stein, R., 1989. Biogenic silica at ODP Site 647 in the southern Labrador Sea: occurrence, diagenesis, and paleoceanographic implications. In Srivastava, S. P., Arthur, M. A., et al., Proc. ODP, Sci. Results, 105: College Station, TX (Ocean Drilling Program), 155-170.

Boyce, R. E., 1976a. Definitions and laboratory techniques of compressional sound velocity parameters and wet-water content, wet-bulk density, and porosity parameters by gravimetric and gamma ray attenuation techniques. In Schlanger, S. O., Jackson, E. D., et al., Init. Repts. DSDP, 33: Washington (U.S. Govt. Printing Office), 931-958.

Brewster, N. A., 1980. Cenozoic biogenic silica sedimentation in the Antarctic Ocean, based on two Deep Sea Drilling Project Sites. Geol. Soc. Am. Bull., 91:337-349.

Bryant, W. R., Bennett, R. H., and Katherman, C. E., 1981. Shear strength, consolidation, porosity, and permeability of oceanic sediments. In Emiliani, C. (Ed.), The Sea (Vol. 7): The Oceanic Lithosphere: New York (Wiley-Interscience), 1555-1616.

Bryant, W. R., and Rack, F. R., 1990. Consolidation characteristics of Weddell Sea sediments: Results of ODP Leg 113. In Barker, P. F., Kennett, J. P., et al., 1988. Proc. ODP, Init. Repts., 113: College Station, TX (Ocean Drilling Program), 211-223.
Ciesielski, P. F., and Grinstead, G. P., 1986. Pliocene variations in the position of the Antarctic Convergence in the southwest Atlantic. Paleoceanography, 1:197-232.

Ciesielski, P. F., Kristoffersen, Y., et al., 1988. Proc. ODP, Init. Repts., 114: College Station, TX (Ocean Drilling Program).

Ciesielski, P. F., and Weaver, F. M., 1983. Neogene and Quaternary paleoenvironmental history of DSDP Leg 71 sediments, southwest Atlantic Ocean. In Ludwig, W. J., Krasheninnikov, V. A., et al., Init. Repts. DSDP, 71: Washington (U.S. Govt. Printing Office), 461-477.

Clemens, S. C., Prell, W. L., and Howard, W. R., 1987. Retrospective dry bulk density estimates from southeast Indian Ocean sediments-comparison of water loss and chloride-ion methods. Mar. Geol., 76:57-69.

Cooke, D. W., and Hays, J. D., 1982. Estimates of Antarctic Ocean seasonal sea-ice cover during glacial intervals. In Craddock, C. (Ed.), Antarctic Geoscience Madison (Univ. of Wisconsin Press), 1017-1025.

Dean, W. E., and Gardner, J. V., 1986. Milankovitch cycles in Neogene deep-sea sediment. Paleoceanography, 1:539-553.

Demars, K. R., 1982. Unique engineering properties and compression behavior of deep-sea calcareous sediments. In Demars, K. R., and Chaney, R. C. (Eds.), Geotechnical Properties, Behavior, and Performance of Calcareous Soils: Philadelphia (Am. Soc. Testing and Materials), 97-112.

DeMaster, D. J., 1979. The marine budgets of silica and ${ }^{32} \mathrm{Si}$. [Ph.D. Dissert.] Yale University, New Haven, CT.

1981. The supply and accumulation of silica in the marine environment. Geochim. Cosmochim. Acta., 45:1715-1732.

Eldholm, O., Thiede, J., Taylor, E., et al., 1987. Proc. ODP, Init. Repts., 104: College Station, TX (Ocean Drilling Program). 1989. Proc. ODP, Sci. Results, 104: College Station, TX (Ocean Drilling Program).

Emery, W. J., 1977. Antarctic Polar Frontal Zone from Australia to the Drake Passage. J. of Phys. Oceanogr., 7:811-822.

Fletcher, J. O., Radok, U., and Slutz, R., 1982. Climatic signals of the Antarctic Ocean. J. Geophys. Res., 87:4269-4276.

Gordon, A. L., and Molinelli, E. J., 1982. Southern Ocean Atlas: New York (Columbia Univ. Press).

Gordon, A. L., Taylor, H. W., and Georgi, D. T., 1978. Antarctic oceanographic zonation. In Dunbar, M. J. (Ed.), Polar Oceans. Proc. Polar Oceans Conf., Calgary (Arctic Inst. North America), 45-76.

Hamilton, E. L., 1976. Variations of density and porosity with depth in deep-sea sediments. J. Sediment. Petrol., 46:280-300.

Hays, J. D., Lozano, J. A., Shackleton, N. J., and Irving, G., 1976. Reconstruction of the Atlantic and western Indian Ocean sectors of the 18,000 B.P. Antarctic Ocean. In Cline, R. M., and Hays, J. D. (Eds.), Investigation of Late Quaternary Paleoceanography and Paleoclimatology. Geol. Soc. Am. Mem., 145:337-372.

Hofmann, E. E., 1985. The large-scale horizontal structure of the Antarctic Circumpolar Current from FGGE drifters. J. Geophys. Res., 90:7087-7097.

Hurd, D. C., and Theyer, F., 1977. Changes in the physical and chemical properties of biogenic silica from the central Equatorial Pacific: Part II. Refractive index, density, and water content of acid-cleaned samples. Am. J. Sci., 277:1168-1202.

Hurd, D. C., Wenkam, C., Pankratz, H. S., and Fugate, J., 1979. Variable porosity in siliceous skeletons: determination and importance. Science, 203:1340-1343.

Kim, D.-C., Manghnani, M. H., and Schlanger, S. O., 1985. The role of diagenesis in the development of physical properties of deep-sea carbonate sediments. Mar. Geol., 69:69-91.

Lee, H. J., 1982. Bulk density and shear strength of several deep-sea calcareous sediments. In Demars, K. R., and Chaney, R. C. (Eds.), Geotechnical Properties, Behavior, and Performance of Calcareous Soils. Philadelphia (Am. Soc. Testing and Materials), 54-96.

Lisitzin, A. P., 1972. Sedimentation in the World Oceans. Tulsa, OK (Banta Press).

1985. The silica cycle during the last ice age. Palaeogeogr., Palaeoclimatol., Palaeoecol., 50:241-270. 
Morley, J. J., 1989. Variations in high-latitude oceanographic fronts in the southern Indian Ocean: an estimation based on faunal changes. Paleoceanography, 4:547-554.

Nowlin, W. D., Jr., and Klinck, J. M., 1986. The physics of the Antarctic Circumpolar Current. Rev. Geophys. Space Phys., 24:469-491.

Pittenger, A., Taylor, E., and Bryant, W. R., 1989. The influence of biogenic silica on the geotechnical stratigraphy of the Vøring Plateau, Norwegian Sea. In Eldholm, O., Theide, J., Taylor, E., et al., Proc. ODP, Sci. Results, 104: College Station, TX (Ocean Drilling Program), 923-940.

Schlich, R., Wise, S. W., Jr., et al., 1989. Proc. ODP, Init. Repts., 120: College Station, TX (Ocean Drilling Program).

Schreiber, B. C., 1968. Sound velocity in deep sea sediments. $J$. Geophys. Res., 73:1259-1268.

Shephard, L. E., and Bryant, W. R., 1980. Consolidation characteristics of Japan Trench sediments. In von Huene, R., Nasu, N., et al., Init. Repts. DSDP, 56, 57 (Pt. 2): Washington (U.S. Govt. Printing Office), 1201-1205.

Skempton, A. W., 1970. The consolidation of clays by gradational compaction. Q. J. Geol. Soc. London, 125:373-411.

Taylor, E., 1984. Oceanic sedimentation and geotechnical stratigraphy: hemipelagic carbonates and red clays [Ph.D. dissert.]. Texas A\&M Univ., College Station, TX.

Valent, P. J., Altschaeffl, A. G., and Lee, H. J., 1982. Geotechnical properties of two calcareous oozes. In Demars, K. R., and Chaney, R. C. (Eds.), Geotechnical Properties, Behavior, and Performance of Calcareous Soils: Philadelphia (Am. Soc. Testing and Materials), 79-96.

Wefer, G., Suess, E., Balzer, W., Liebezeit, G., Muller, P. J., Ungerer, A., and Wenk, W., 1982. Fluxes of biogenic components from sediment trap deployment in circumpolar waters of Drake Passage. Nature, 299:145-147.
Whitworth, T., III, 1983. Monitoring the transport of the Antarctic Circumpolar Current at Drake Passage. J. Phys. Oceanogr., 13:2045-2057.

Wilkens, R. H., and Handyside, T., 1985. Physical properties of equatorial Pacific sediments. In Mayer, L., Theyer, F., Thomas, E., et al., Init. Repts. DSDP, 85: Washington (U.S. Govt. Printing Office), 839-847.

Wilkens, R. H., Schreiber, B. C., Caruso, L., and Simmons, G., 1987. The effects of diagenesis on the microstructure of Eocene sediments bordering the Baltimore Canyon Trough. In Poag, C. W. Watts, A. B., et al., Init. Repts. DSDP, 95: Washington (U.S. Govt. Printing Office), 527-547.

Williams, D. F., Gribble, D., Healy-Williams, N., and Leschak, P., 1985. Dissolution and water-mass patterns in the Southeast Indian Ocean. Part II: the Pleistocene record from Brunhes to Matuyama age sediments. Geol. Soc. Am. Bull., 96:190-202.

Williams, D. F., Healy-Williams, N., and Leschak, P., 1985. Dissolution and water-mass patterns in the Southeast Indian Ocean. Part I: evidence from recent to late Holocene foraminiferal assemblages. Geol. Soc. Am. Bull., 96:176-189.

Wise, S. W., Jr., Cielsielski, P. F., MacKenzie, D. T., Wind, F. H., Busen, K. E., Gombos, A. M., Haq, B. U., Lohman, G. P., Tjalsma, R. C., Harris, W. K., Hedlund, R. W., Beju, D. N., Jones, D. L., Plafker, G., and Sliter, W. V., 1982. Paleontologic and paleoenvironmental synthesis for the southwest Atlantic Ocean Basin based on Jurassic to Holocene faunas and floras from the Falkland Plateau. In Craddock, C. (Ed.), Antarctic Geoscience: Madison (Univ. of Wisconsin Press), 155-163.

Date of initial receipt: 20 February 1990

Date of acceptance: 1 November 1990

Ms 120B-145 
Appendix A

Absolute Accumulation Rates, Site 751.

\begin{tabular}{|c|c|c|c|c|c|c|c|c|c|c|c|}
\hline $\begin{array}{l}\text { Core, section, } \\
\text { interval (top) }\end{array}$ & $\begin{array}{l}\text { Depth } \\
\text { (mbsf) }\end{array}$ & $\begin{array}{c}\text { Age } \\
\text { (m.y.) }\end{array}$ & $\begin{array}{l}\mathrm{CaCO}_{3} \\
\text { (shore) }\end{array}$ & $\begin{array}{l}\mathrm{CaCO}_{3} \\
\text { (ship) }\end{array}$ & $\mathrm{SiO}_{2}$ & LSR & DBD & $\begin{array}{l}\text { Bulk } \\
\text { AAR }\end{array}$ & $\begin{array}{c}\mathrm{CaCO}_{3} \\
\mathrm{AAR}\end{array}$ & $\begin{array}{l}\mathrm{SiO}_{2} \\
\mathrm{AAR}\end{array}$ & $\begin{array}{c}\text { Non- } \mathrm{CaCO}_{3} \\
\text { AAR }\end{array}$ \\
\hline \multicolumn{12}{|l|}{$120-751 \mathrm{~A}-$} \\
\hline $1 \mathrm{H}-1,30$ & 0.30 & 0.00 & 15.34 & & & 3 & 0.32 & 0.96 & 0.147 & & 0.813 \\
\hline $1 \mathrm{H}-1,70$ & 0.70 & 0.10 & 11.96 & 11.00 & & 3 & 0.45 & 1.35 & 0.161 & & 1.189 \\
\hline $1 \mathrm{H}-1,115$ & 1.15 & 0.20 & 12.68 & & & 3 & 0.35 & 1.05 & 0.133 & & 0.917 \\
\hline $1 \mathrm{H}-2,30$ & 1.80 & 0.45 & 14.85 & & & 3 & 0.33 & 0.99 & 0.147 & & 0.843 \\
\hline $1 \mathrm{H}-2,48$ & 1.98 & 0.50 & 17.4 & 15.20 & & 3 & 0.51 & 1.53 & 0.266 & & 1.264 \\
\hline $1 \mathrm{H}-3,30$ & 3.30 & 0.90 & 71.46 & 71.30 & & 3 & 0.76 & 2.28 & 1.629 & & 0.651 \\
\hline $2 \mathrm{H}-1,115$ & 5.85 & 1.90 & 62.65 & & & 3 & 0.64 & 1.92 & 1.203 & & 0.717 \\
\hline $2 \mathrm{H}-2,30$ & 6.50 & 2.20 & 22.38 & & 19.2 & 3 & 0.45 & 1.35 & 0.302 & 0.259 & 1.048 \\
\hline $2 \mathrm{H}-2,70$ & 6.90 & 2.40 & 30.74 & 31.20 & 47.3 & 3 & 0.44 & 1.32 & 0.406 & 0.624 & 0.914 \\
\hline $2 \mathrm{H}-2,115$ & 7.35 & 2.80 & 27.55 & & & 3 & 0.57 & 1.71 & 0.471 & & 1.239 \\
\hline $2 \mathrm{H}-3,30$ & 8.00 & 2.84 & 5.18 & & & 20 & 0.25 & 5.00 & 0.259 & & 4.741 \\
\hline $2 \mathrm{H}-3,70$ & 8.40 & 2.90 & 35.82 & 35.20 & 63.8 & 20 & 0.52 & 10.40 & 3.725 & 6.635 & 6.675 \\
\hline $2 \mathrm{H}-3,115$ & 8.85 & 2.93 & 1.63 & & & 20 & 0.29 & 5.80 & 0.095 & & 5.705 \\
\hline $2 \mathrm{H}-4,30$ & 9.50 & 3.10 & 0.00 & 1.40 & 69.1 & 20 & 0.20 & 4.00 & 0.000 & 2.764 & 4.000 \\
\hline $3 \mathrm{H}-1,20$ & 14.40 & 3.35 & 0.00 & & 73.4 & 20 & 1.45 & & 0.000 & & \\
\hline $3 \mathrm{H}-1,70$ & 14.90 & 3.38 & 0.00 & 0.70 & 76.1 & 20 & 0.33 & 6.60 & 0.000 & 5.023 & 6.600 \\
\hline $3 \mathrm{H}-1,115$ & 15.35 & 3.40 & 0.14 & & & 20 & 0.30 & 6.00 & 0.008 & & 5.992 \\
\hline $3 \mathrm{H}-2,30$ & 16.00 & 3.44 & 0.40 & & 66.4 & 20 & 0.37 & 7.40 & 0.030 & 4.914 & 7.370 \\
\hline $3 \mathrm{H}-2,70$ & 16.40 & 3.60 & 0.29 & 0.40 & 72.1 & 20 & 0.38 & 7.60 & 0.022 & 5.480 & 7.578 \\
\hline $3 \mathrm{H}-2,115$ & 16.85 & 3.63 & 0.64 & & & 20 & 0.38 & 7.60 & 0.049 & & 7.551 \\
\hline $3 \mathrm{H}-3,70$ & 17.90 & 3.68 & 0.72 & 0.80 & 58.6 & 20 & 0.37 & 7.40 & 0.053 & 4.336 & 7.347 \\
\hline $3 \mathrm{H}-3,115$ & 18.35 & 3.73 & 10.51 & & & 20 & 0.38 & 7.60 & 0.799 & & 6.801 \\
\hline $3 \mathrm{H}-4,30$ & 19.00 & 3.80 & 6.65 & & 69.1 & 20 & 0.43 & 8.60 & 0.572 & 5.943 & 8.028 \\
\hline $3 \mathrm{H}-4,70$ & 19.40 & 3.82 & 13.79 & 13.10 & 67.7 & 20 & 0.40 & 8.00 & 1.103 & 5.416 & 6.897 \\
\hline $3 \mathrm{H}-4,115$ & 19.85 & 3.85 & 9.09 & & & 20 & 0.35 & 7.00 & 0.636 & & 6.364 \\
\hline $3 \mathrm{H}-5,30$ & 20.50 & 3.89 & 7.04 & & 63.7 & 20 & 0.33 & 6.60 & 0.465 & 4.204 & 6.135 \\
\hline $3 \mathrm{H}-5,70$ & 20.90 & 3.91 & 11.16 & 11.20 & 53.3 & 20 & 0.37 & 7.40 & 0.826 & 3.944 & 6.574 \\
\hline $3 \mathrm{H}-5,115$ & 21.35 & 3.93 & 8.72 & & 69.0 & 20 & 0.34 & 6.80 & 0.593 & 4.692 & 6.207 \\
\hline $4 \mathrm{H}-2,110$ & 26.30 & 4.18 & 0.00 & 0.10 & 61.2 & 20 & 0.39 & 7.80 & 0.000 & 4.774 & 7.800 \\
\hline $4 \mathrm{H}-3,30$ & 27.00 & 4.21 & 1.17 & & & 20 & 0.27 & 5.40 & 0.063 & & 5.337 \\
\hline $4 \mathrm{H}-3,67$ & 27.37 & 4.22 & 0.11 & 0.20 & 62.1 & 20 & 0.26 & 5.20 & 0.006 & 3.229 & 5.194 \\
\hline $4 \mathrm{H}-3,113$ & 27.83 & 4.24 & 1.43 & & & 20 & 0.39 & 7.80 & 0.112 & & 7.688 \\
\hline $4 \mathrm{H}-4,30$ & 28.50 & 4.25 & 0.00 & & & 20 & 0.31 & 6.20 & 0.000 & & 6.200 \\
\hline $4 \mathrm{H}-4,67$ & 28.87 & 4.27 & 0.65 & 0.30 & 64.7 & 20 & 0.38 & 7.60 & 0.049 & 4.917 & 7.551 \\
\hline $4 \mathrm{H}-4,112$ & 29.32 & 4.29 & 14.85 & & & 20 & 0.44 & 8.80 & 1.307 & & 7.493 \\
\hline $4 \mathrm{H}-5,30$ & 30.00 & 4.32 & 0.58 & & & 20 & 0.40 & 8.00 & 0.046 & & 7.954 \\
\hline $4 \mathrm{H}-5,67$ & 30.37 & 4.33 & 24.39 & 23.70 & 64.5 & 20 & 0.51 & 10.20 & 2.488 & 6.579 & 7.712 \\
\hline $4 \mathrm{H}-5,113$ & 30.83 & 4.35 & 5.67 & & & 20 & 0.35 & 7.00 & 0.397 & & 6.603 \\
\hline $4 \mathrm{H}-6,30$ & 31.50 & 4.39 & 0.26 & & & 20 & 0.38 & 7.60 & 0.020 & & 7.580 \\
\hline $4 \mathrm{H}-6,70$ & 31.90 & 4.41 & 0.00 & 0.20 & 51.3 & 20 & 0.40 & 8.00 & 0.000 & 4.104 & 8.000 \\
\hline $4 \mathrm{H}-6,113$ & 32.33 & 4.43 & 0.00 & & & 20 & 0.29 & 5.80 & 0.000 & & 5.800 \\
\hline $5 \mathrm{H}-1,30$ & 33.50 & 4.47 & 0.00 & & & 20 & 0.35 & 7.00 & 0.000 & & 7.000 \\
\hline $5 \mathrm{H}-1,70$ & 33.90 & 4.49 & 0.00 & 0.20 & & 20 & 0.22 & 4.40 & 0.000 & & 4.400 \\
\hline $5 \mathrm{H}-1,115$ & 34.35 & 4.51 & 0.00 & & & 20 & 0.34 & 6.80 & 0.000 & & 6.800 \\
\hline $5 \mathrm{H}-2,30$ & 35.00 & 4.52 & 0.00 & & & 20 & 0.30 & 6.00 & 0.000 & & 6.000 \\
\hline $5 \mathrm{H}-2,70$ & 35.40 & 4.54 & 0.00 & 0.10 & 61.9 & 20 & 0.39 & 7.80 & 0.000 & 4.828 & 7.800 \\
\hline $5 \mathrm{H}-2,115$ & 35.85 & 4.55 & 0.00 & & & 20 & 0.41 & 8.20 & 0.000 & & 8.200 \\
\hline $5 \mathrm{H}-3,30$ & 36.50 & 4.57 & 0.00 & & & 20 & 0.39 & 7.80 & 0.000 & & 7.800 \\
\hline $5 \mathrm{H}-3,70$ & 36.90 & 4.59 & 0.00 & 0.10 & & 20 & 0.37 & 7.40 & 0.000 & & 7.400 \\
\hline $5 \mathrm{H}-3,115$ & 37.35 & 4.61 & 0.00 & & & 20 & 0.41 & 8.20 & 0.000 & & 8.200 \\
\hline $5 \mathrm{H}-4,30$ & 38.00 & 4.63 & 0.00 & & & 20 & 0.36 & 7.20 & 0.000 & & 7.200 \\
\hline $5 \mathrm{H}-4,70$ & 38.40 & 4.65 & 0.00 & 0.10 & 45.4 & 20 & 0.44 & 8.80 & 0.000 & 3.995 & 8.800 \\
\hline $5 \mathrm{H}-4,115$ & 38.85 & 4.67 & 0.00 & & & 20 & 0.45 & 9.00 & 0.000 & & 9.000 \\
\hline $5 \mathrm{H}-5,30$ & 39.50 & 4.69 & 0.00 & & & 20 & 0.50 & 10.00 & 0.000 & & 10.000 \\
\hline $5 \mathrm{H}-5,70$ & 39.90 & 4.70 & 0.00 & 0.10 & & 20 & 0.55 & 11.00 & 0.000 & & 11.000 \\
\hline SH-5, 115 & 40.35 & 5.30 & 72.49 & & 13.5 & 10 & 0.77 & 7.70 & 5.582 & 1.040 & 2.118 \\
\hline $5 \mathrm{H}-6,30$ & 41.00 & 5.37 & 74.35 & 74.50 & & 10 & 0.87 & 8.70 & 6.468 & & 2.232 \\
\hline $6 \mathrm{H}-1,70$ & 43.40 & 5.59 & 67.95 & 67.10 & & 10 & 0.89 & 8.90 & 6.048 & & 2.852 \\
\hline $6 \mathrm{H}-1,115$ & 43.85 & 5.63 & 71.13 & & & 10 & 0.92 & 9.20 & 6.544 & & 2.656 \\
\hline $6 \mathrm{H}-2,30$ & 44.50 & 5.69 & 59.92 & & & 10 & 0.80 & 8.00 & 4.794 & & 3.206 \\
\hline $6 \mathrm{H}-2,70$ & 44.90 & 5.73 & 63.02 & 60.10 & 13.3 & 10 & 0.79 & 7.90 & 4.979 & 1.051 & 2.921 \\
\hline $6 \mathrm{H}-2,115$ & 45.35 & 5.77 & 78.07 & & & 10 & 0.92 & 9.20 & 7.182 & & 2.018 \\
\hline $6 \mathrm{H}-3,30$ & 46.00 & 5.81 & 77.87 & & & 10 & 0.89 & 8.90 & 6.930 & & 1.970 \\
\hline $6 \mathrm{H}-3,70$ & 46.40 & 5.85 & 71.57 & 71.20 & 12.7 & 10 & 0.89 & 8.90 & 6.370 & 1.130 & 2.530 \\
\hline $6 \mathrm{H}-3,115$ & 46.85 & 5.89 & 67.59 & & & 10 & 0.81 & 8.10 & 5.475 & & 2.625 \\
\hline $6 \mathrm{H}-4,30$ & 47.50 & 5.93 & 76.08 & & 12.9 & 10 & 0.87 & 8.70 & 6.619 & 1.122 & 2.081 \\
\hline $6 \mathrm{H}-4,70$ & 47.90 & 5.96 & 77.29 & 74.70 & 8.0 & 10 & 0.89 & 8.90 & 6.879 & 0.712 & 2.021 \\
\hline $6 \mathrm{H}-4,115$ & 48.35 & 5.99 & 76.81 & & 19.0 & 10 & 0.93 & 9.30 & 7.143 & 1.767 & 2.157 \\
\hline $6 \mathrm{H}-5,30$ & 49.00 & 6.03 & 84.34 & & & 10 & 0.97 & 9.70 & 8.181 & & 1.519 \\
\hline $6 \mathrm{H}-5,70$ & 49.40 & 6.07 & 70.91 & 68.20 & & 10 & 0.81 & 8.10 & 5.744 & & 2.356 \\
\hline $6 \mathrm{H}-5,115$ & 49.85 & 6.10 & 67.18 & & & 10 & 0.79 & 7.90 & 5.307 & & 2.593 \\
\hline $6 \mathrm{H}-6,30$ & 50.50 & 6.13 & 79.53 & & & 10 & 0.83 & 8.30 & 6.601 & & 1.699 \\
\hline $6 \mathrm{H}-6,70$ & 50.90 & 6.16 & 67.21 & 64.10 & & 10 & 0.80 & 8.00 & 5.377 & & 2.623 \\
\hline $6 \mathrm{H}-6,115$ & 51.35 & 6.19 & 71.07 & & 11.2 & 10 & 0.94 & 9.40 & 6.681 & 1.053 & 2.719 \\
\hline
\end{tabular}


Appendix A (continued).

Absolute Accumulation Rates, Site 751.

\begin{tabular}{|c|c|c|c|c|c|c|c|c|c|c|c|}
\hline $\begin{array}{l}\text { Core, section, } \\
\text { interval (top) }\end{array}$ & $\begin{array}{l}\text { Depth } \\
\text { (mbsf) }\end{array}$ & $\begin{array}{c}\text { Age } \\
\text { (m.y.) }\end{array}$ & $\begin{array}{l}\mathrm{CaCO}_{3} \\
\text { (shore) }\end{array}$ & $\begin{array}{c}\mathrm{CaCO}_{3} \\
\text { (ship) }\end{array}$ & $\mathrm{SiO}_{2}$ & LSR & DBD & $\begin{array}{l}\text { Bulk } \\
\text { AAR }\end{array}$ & $\begin{array}{c}\mathrm{CaCO}_{3} \\
\mathrm{AAR}^{2}\end{array}$ & $\begin{array}{l}\mathrm{SiO}_{2} \\
\mathrm{AAR}\end{array}$ & $\begin{array}{c}\text { Non- } \mathrm{CaCO}_{3} \\
\mathrm{AAR}\end{array}$ \\
\hline $6 \mathrm{H}-7,30$ & 52.00 & 6.22 & 67.28 & & & 10 & 0.82 & 8.20 & 5.517 & & 2.683 \\
\hline $7 \mathrm{H}-2,30$ & 54.00 & 6.25 & 80.58 & & & 10 & 0.91 & 9.10 & 7.333 & & 1.767 \\
\hline $7 \mathrm{H}-2,70$ & 54.40 & 6.28 & 80.71 & 78.90 & & 10 & 0.91 & 9.10 & 7.345 & & 1.755 \\
\hline $7 \mathrm{H}-2,115$ & 54.85 & 9.50 & 86.89 & & & 20 & 0.97 & 19.40 & 16.857 & & 2.543 \\
\hline $7 \mathrm{H}-3,30$ & 55.50 & 9.53 & 86.28 & & & 20 & 0.99 & 19.80 & 17.083 & & 2.717 \\
\hline $7 \mathrm{H}-3,70$ & 55.90 & 9.56 & 85.49 & 83.50 & & 20 & 0.98 & 19.60 & 16.756 & & 2.844 \\
\hline $7 \mathrm{H}-3,115$ & 56.35 & 9.59 & 90.84 & & & 20 & 1.06 & 21.20 & 19.258 & & 1.942 \\
\hline $7 \mathrm{H}-4,30$ & 57.00 & 9.62 & 87.31 & & & 20 & 0.97 & 19.40 & 16.938 & & 2.462 \\
\hline $7 \mathrm{H}-4,70$ & 57.40 & 9.64 & 83.19 & 81.60 & & 20 & 0.96 & 19.20 & 15.972 & & 3.228 \\
\hline $7 \mathrm{H}-4,115$ & 57.85 & 9.67 & 84.73 & & & 20 & 0.97 & 19.40 & 16.438 & & 2.962 \\
\hline $7 \mathrm{H}-5,30$ & 58.50 & 9.70 & 82.76 & & & 20 & 0.91 & 18.20 & 15.062 & & 3.138 \\
\hline $7 \mathrm{H}-5,70$ & 58.90 & 9.73 & 77.81 & 74.60 & & 20 & 0.87 & 17.40 & 13.539 & & 3.861 \\
\hline $7 \mathrm{H}-5,115$ & 59.35 & 9.75 & 84.69 & & & 20 & 0.94 & 18.80 & 15.922 & & 2.878 \\
\hline $7 \mathrm{H}-6,30$ & 60.00 & 9.77 & 87.91 & & & 20 & 1.05 & 21.00 & 18.461 & & 2.539 \\
\hline $7 \mathrm{H}-6,70$ & 60.40 & 9.79 & 88.05 & 85.60 & & 20 & 1.13 & 22.60 & 19.899 & & 2.701 \\
\hline $7 \mathrm{H}-6,115$ & 60.85 & 9.81 & 75.06 & & & 20 & 0.82 & 16.40 & 12.310 & & 4.090 \\
\hline $7 \mathrm{H}-7,30$ & 61.50 & 9.84 & 78.77 & 76.60 & & 20 & 0.80 & 16.00 & 12.603 & & 3.397 \\
\hline $8 \mathrm{H}-3,30$ & 65.00 & 10.01 & 57.02 & & & 20 & 0.70 & 14.00 & 7.983 & & 6.017 \\
\hline $8 \mathrm{H}-3,70$ & 65.40 & 10.03 & 70.95 & 69.20 & & 20 & 0.76 & 15.20 & 10.784 & & 4.416 \\
\hline $8 \mathrm{H}-3,115$ & 65.85 & 10.05 & 69.29 & & & 20 & 0.74 & 14.80 & 10.255 & & 4.545 \\
\hline $8 \mathrm{H}-4,30$ & 66.50 & 10.07 & 66.20 & & & 20 & 0.74 & 14.80 & 9.798 & & 5.002 \\
\hline $8 \mathrm{H}-4,70$ & 66.90 & 10.09 & 42.92 & 42.00 & & 20 & 0.59 & 11.80 & 5.065 & & 6.735 \\
\hline $8 \mathrm{H}-4,115$ & 67.35 & 10.11 & 56.42 & & & 20 & 0.70 & 14.00 & 7.899 & & 6.101 \\
\hline $8 \mathrm{H}-5,30$ & 68.00 & 10.13 & 46.95 & & & 20 & 0.64 & 12.80 & 6.010 & & 6.790 \\
\hline $8 \mathrm{H}-5,70$ & 68.40 & 10.15 & 42.94 & 42.30 & & 20 & 0.63 & 12.60 & 5.410 & & 7.190 \\
\hline $8 \mathrm{H}-5,115$ & 68.85 & 10.17 & 51.35 & & & 20 & 0.75 & 15.00 & 7.703 & & 7.297 \\
\hline $8 \mathrm{H}-6,30$ & 69.50 & 10.19 & 50.58 & & & 20 & 0.67 & 13.40 & 6.778 & & 6.622 \\
\hline $9 \mathrm{H}-1,30$ & 71.50 & 10.29 & 65.41 & & & 20 & 0.68 & 13.60 & 8.896 & & 4.704 \\
\hline $9 \mathrm{H}-1,70$ & 71.90 & 10.31 & 69.25 & 69.10 & & 20 & 0.75 & 15.00 & 10.387 & & 4.613 \\
\hline $9 \mathrm{H}-1,115$ & 72.35 & 10.33 & 65.70 & & & 20 & 0.75 & 15.00 & 9.855 & & 5.145 \\
\hline $9 \mathrm{H}-2,30$ & 73.00 & 10.35 & 62.23 & & & 20 & 0.72 & 14.40 & 8.961 & & 5.439 \\
\hline $9 \mathrm{H}-2,70$ & 73.40 & 10.37 & 51.50 & 51.10 & & 20 & 0.65 & 13.00 & 6.695 & & 6.305 \\
\hline $9 \mathrm{H}-2,115$ & 73.85 & 10.39 & 54.03 & & & 20 & 0.68 & 13.60 & 7.348 & & 6.252 \\
\hline $9 \mathrm{H}-3,30$ & 74.50 & 10.41 & 48.39 & & & 20 & 0.64 & 12.80 & 6.194 & & 6.606 \\
\hline $9 \mathrm{H}-3,70$ & 74.90 & 10.43 & 56.66 & 55.50 & & 20 & 0.70 & 14.00 & 7.932 & & 6.068 \\
\hline $9 \mathrm{H}-3,115$ & 75.35 & 10.45 & 66.09 & & & 20 & 0.81 & 16.20 & 10.707 & & 5.493 \\
\hline $9 \mathrm{H}-4,30$ & 76.00 & 10.48 & 64.01 & & & 20 & 0.80 & 16.00 & 10.242 & & 5.758 \\
\hline $9 \mathrm{H}-4,70$ & 76.40 & 10.50 & 80.31 & & & 20 & 0.99 & 19.80 & 15.901 & & 3.899 \\
\hline $9 \mathrm{H}-4,115$ & 76.85 & 10.52 & 82.18 & 79.80 & & 20 & 0.92 & 18.40 & 15.121 & & 3.279 \\
\hline $9 \mathrm{H}-5,30$ & 77.50 & 10.54 & 79.53 & & 12.9 & 20 & 0.90 & 18.00 & 14.315 & 2.322 & 3.685 \\
\hline $9 \mathrm{H}-5,70$ & 77.90 & 10.56 & 76.35 & 76.60 & 20.0 & 20 & 0.88 & 17.60 & 13.438 & 3.520 & 4.162 \\
\hline $9 \mathrm{H}-5,115$ & 78.35 & 10.58 & 77.59 & 76.05 & & 20 & 0.88 & 17.60 & 13.656 & & 3.944 \\
\hline $9 \mathrm{H}-6,30$ & 79.00 & 10.60 & 67.53 & 68.47 & & 20 & 0.80 & 16.00 & 10.805 & & 5.195 \\
\hline $9 \mathrm{H}-6,70$ & 79.40 & 10.62 & 70.25 & 69.40 & & 20 & 0.81 & 16.20 & 11.381 & & 4.820 \\
\hline $9 \mathrm{H}-6,115$ & 79.85 & 10.64 & 71.63 & 58.56 & & 20 & 0.81 & 16.20 & 11.604 & & 4.596 \\
\hline $9 \mathrm{H}-7,30$ & 80.50 & 10.66 & 70.30 & 68.81 & & 20 & & & & & \\
\hline $9 \mathrm{H}-7,70$ & 80.90 & 10.68 & 71.18 & 69.80 & & 20 & 0.84 & 16.80 & 11.958 & & 4.842 \\
\hline $10 \mathrm{H}-1,70$ & 81.40 & 10.71 & 79.79 & 80.00 & & 20 & 0.97 & 19.40 & 15.479 & & 3.921 \\
\hline $10 \mathrm{H}-1,115$ & 81.85 & 10.73 & 82.57 & 81.72 & & 20 & 0.92 & 18.40 & 15.193 & & 3.207 \\
\hline $10 \mathrm{H}-2,30$ & 82.50 & 10.75 & 81.08 & 80.55 & & 20 & 0.94 & 18.80 & 15.243 & & 3.557 \\
\hline $10 \mathrm{H}-2,70$ & 82.90 & 10.77 & 80.36 & 79.20 & & 20 & 0.88 & 17.60 & 14.143 & & 3.457 \\
\hline $10 \mathrm{H}-2,115$ & 83.35 & 10.79 & 84.01 & 82.88 & & 20 & 0.89 & 17.80 & 14.954 & & 2.846 \\
\hline $10 \mathrm{H}-3,30$ & 84.00 & 10.82 & 83.52 & 83.55 & & 20 & 0.91 & 18.20 & 15.201 & & 2.999 \\
\hline $10 \mathrm{H}-3,70$ & 84.40 & 10.84 & 84.83 & 84.60 & & 20 & 1.04 & 20.80 & 17.645 & & 3.155 \\
\hline $10 \mathrm{H}-3,115$ & 84.85 & 10.86 & 83.76 & 82.55 & & 20 & 0.98 & 19.60 & 16.417 & & 3.183 \\
\hline $10 \mathrm{H}-4,30$ & 85.50 & 10.88 & 74.32 & 74.05 & & 20 & 0.84 & 16.80 & 12.486 & & 4.314 \\
\hline $10 \mathrm{H}-4,70$ & 85.90 & 10.90 & 73.91 & 72.70 & & 20 & 0.81 & 16.20 & 11.973 & & 4.227 \\
\hline $10 \mathrm{H}-4,115$ & 86.35 & 10.92 & 79.68 & 78.47 & & 20 & 0.91 & 18.20 & 14.502 & & 3.698 \\
\hline $10 \mathrm{H}-5,30$ & 87.00 & 10.95 & 81.36 & 79.30 & & 20 & 0.95 & 19.00 & 15.458 & & 3.542 \\
\hline $10 \mathrm{H}-5,70$ & 87.40 & 10.97 & 80.18 & 80.10 & & 20 & 0.87 & 17.40 & 13.951 & & 3.449 \\
\hline $10 \mathrm{H}-5,115$ & 87.85 & 10.99 & 83.98 & 83.72 & & 20 & 0.98 & 19.60 & 16.460 & & 3.140 \\
\hline $10 \mathrm{H}-6,30$ & 88.50 & 10.02 & 81.59 & 82.22 & & 20 & 0.94 & 18.80 & 15.339 & & 3.461 \\
\hline $10 \mathrm{H}-6,70$ & 88.90 & 11.04 & 79.37 & 80.05 & & 20 & 0.87 & 17.40 & 13.810 & & 3.590 \\
\hline $10 \mathrm{H}-6,115$ & 89.35 & 11.06 & 81.35 & 81.55 & & 20 & 0.92 & 18.40 & 14.968 & & 3.432 \\
\hline $10 \mathrm{H}-7,30$ & 90.00 & 11.08 & 83.58 & 82.22 & & 20 & 0.94 & 18.80 & 15.713 & & 3.087 \\
\hline $11 \mathrm{H}-1,30$ & 90.50 & 11.11 & 81.05 & 80.80 & & 20 & 0.91 & 18.20 & 14.751 & & 3.449 \\
\hline $11 \mathrm{H}-1,70$ & 90.90 & 11.13 & 80.33 & 80.10 & & 20 & 0.89 & 17.80 & 14.299 & & 3.501 \\
\hline $11 \mathrm{H}-1,115$ & 91.35 & 11.15 & 90.81 & 89.46 & & 20 & 1.03 & 20.60 & 18.707 & & 1.893 \\
\hline $11 \mathrm{H}-2,30$ & 92.00 & 11.17 & 88.33 & 88.72 & & 20 & 1.04 & 20.80 & 18.373 & & 2.427 \\
\hline $11 \mathrm{H}-2,70$ & 92.40 & 11.19 & 86.58 & 86.00 & & 20 & 1.00 & 20.00 & 17.316 & & 2.684 \\
\hline $11 \mathrm{H}-2,115$ & 92.85 & 11.21 & 86.70 & 85.13 & & 20 & 1.07 & 21.40 & 18.554 & & 2.846 \\
\hline $11 \mathrm{H}-3,30$ & 93.50 & 11.23 & 91.72 & 92.13 & & 20 & 1.07 & 21.40 & 19.628 & & 1.772 \\
\hline $11 \mathrm{H}-3,70$ & 93.90 & 11.25 & 88.31 & 87.20 & & 20 & 0.99 & 19.80 & 17.485 & & 2.315 \\
\hline $11 \mathrm{H}-3,115$ & 94.35 & 11.27 & 85.10 & 85.55 & & 20 & 1.03 & 20.60 & 17.531 & & 3.069 \\
\hline $11 \mathrm{H}-4,30$ & 95.00 & 11.29 & 83.25 & 82.55 & & 20 & 0.94 & 18.80 & 15.651 & & 3.149 \\
\hline
\end{tabular}


Appendix A (continued).

Absolute Accumulation Rates, Site 751.

\begin{tabular}{|c|c|c|c|c|c|c|c|c|c|c|c|}
\hline $\begin{array}{l}\text { Core, section, } \\
\text { interval (top) }\end{array}$ & $\begin{array}{l}\text { Depth } \\
\text { (mbsf) }\end{array}$ & $\begin{array}{l}\text { Age } \\
\text { (m.y.) }\end{array}$ & $\begin{array}{l}\mathrm{CaCO}_{3} \\
\text { (shore) }\end{array}$ & $\begin{array}{c}\mathrm{CaCO}_{3} \\
\text { (ship) }\end{array}$ & $\mathrm{SiO}_{2}$ & LSR & DBD & $\begin{array}{l}\text { Bulk } \\
\text { AAR }\end{array}$ & $\begin{array}{c}\mathrm{CaCO}_{3} \\
\mathrm{AAR}^{-}\end{array}$ & $\begin{array}{l}\mathrm{SiO}_{2} \\
\mathrm{AAR}\end{array}$ & $\begin{array}{c}\text { Non- } \mathrm{CaCO}_{3} \\
\text { AAR }\end{array}$ \\
\hline $11 \mathrm{H}-4,70$ & 95.40 & 11.31 & 78.06 & 77.50 & & 20 & 0.93 & 18.60 & 14.519 & & 4.081 \\
\hline $11 \mathrm{H}-4,115$ & 95.85 & 11.33 & 69.13 & 69.14 & & 20 & 0.84 & 16.80 & 11.614 & & 5.186 \\
\hline $11 \mathrm{H}-4,135$ & 96.05 & 11.35 & 59.17 & 61.89 & & 20 & 0.64 & 12.80 & 7.574 & & 5.226 \\
\hline $11 \mathrm{H}-5,30$ & 96.50 & 11.37 & 72.50 & 72.05 & & 20 & 0.77 & 15.40 & 11.165 & & 4.235 \\
\hline $11 \mathrm{H}-5,70$ & 96.90 & 11.39 & 82.38 & 80.20 & & 20 & 0.91 & 18.20 & 14.993 & & 3.207 \\
\hline $11 \mathrm{H}-5,115$ & 97.35 & 11.41 & 84.82 & 83.63 & & 20 & 0.95 & 19.00 & 16.116 & & 2.884 \\
\hline $11 \mathrm{H}-6,30$ & 98.00 & 11.44 & 70.50 & 70.64 & & 20 & 0.78 & 15.60 & 10.998 & & 4.602 \\
\hline $11 \mathrm{H}-6,70$ & 98.40 & 11.47 & 72.53 & 72.30 & & 20 & 0.84 & 16.80 & 12.185 & & 4.615 \\
\hline $11 \mathrm{H}-6,115$ & 98.85 & 11.50 & 51.22 & 50.75 & & 20 & 0.79 & 15.80 & 8.093 & & 7.707 \\
\hline $11 \mathrm{H}-7,30$ & 99.50 & 11.53 & 53.66 & 54.22 & & 20 & 0.71 & 14.20 & 7.620 & & 6.580 \\
\hline $12 \mathrm{H}-1,30$ & 100.00 & 11.56 & 59.94 & 61.06 & & 20 & 0.80 & 16.00 & 9.590 & & 6.410 \\
\hline $12 \mathrm{H}-1,70$ & 100.40 & 11.59 & 42.90 & 42.90 & & 20 & 0.64 & 12.80 & 5.491 & & 7.309 \\
\hline $12 \mathrm{H}-1,115$ & 100.85 & 11.62 & 51.66 & 51.40 & & 20 & 0.69 & 13.80 & 7.129 & & 6.671 \\
\hline $12 \mathrm{H}-2,30$ & 101.50 & 11.65 & 45.86 & 47.73 & & 20 & 0.65 & 13.00 & 5.962 & & 7.038 \\
\hline $12 \mathrm{H}-2,70$ & 101.90 & 11.68 & 46.12 & 46.70 & & 20 & 0.64 & 12.80 & 5.903 & & 6.897 \\
\hline $12 \mathrm{H}-2,115$ & 102.35 & 11.71 & 56.23 & 57.81 & & 20 & 0.68 & 13.60 & 7.647 & & 5.953 \\
\hline $12 \mathrm{H}-3,30$ & 103.00 & 11.74 & 62.48 & 62.56 & & 20 & 0.80 & 16.00 & 9.997 & & 6.003 \\
\hline $12 \mathrm{H}-3,70$ & 103.40 & 11.77 & 67.43 & 67.30 & & 20 & 0.85 & 17.00 & 11.463 & & 5.537 \\
\hline $12 \mathrm{H}-3,115$ & 103.85 & 11.80 & 60.04 & 60.89 & & 20 & 0.81 & 16.20 & 9.726 & & 6.474 \\
\hline $12 \mathrm{H}-4,30$ & 104.50 & 11.83 & 70.86 & 70.90 & 10.2 & 20 & 0.93 & 18.60 & 13.180 & 1.897 & 5.420 \\
\hline $12 \mathrm{H}-4,70$ & 104.90 & 11.86 & 66.07 & 65.70 & 13.7 & 20 & 0.98 & 19.60 & 12.950 & 2.685 & 6.650 \\
\hline $12 \mathrm{H}-4,115$ & 105.35 & 11.89 & 71.04 & 71.06 & & 20 & 0.98 & 19.60 & 13.924 & & 5.676 \\
\hline $12 \mathrm{H}-5,30$ & 106.00 & 11.92 & 63.78 & 63.97 & & 20 & 0.95 & 19.00 & 12.118 & & 6.882 \\
\hline $12 \mathrm{H}-5,70$ & 106.40 & 11.95 & 69.97 & 69.60 & & 20 & 1.01 & 20.20 & 14.134 & & 6.066 \\
\hline $12 \mathrm{H}-5,115$ & 106.85 & 11.97 & 60.47 & 59.48 & & 20 & 0.84 & 16.80 & 10.159 & & 6.641 \\
\hline $12 \mathrm{H}-6,30$ & 107.50 & 12.00 & 55.21 & 56.64 & & 20 & 0.83 & 16.60 & 9.165 & & 7.435 \\
\hline $12 \mathrm{H}-6,70$ & 107.90 & 12.03 & 59.10 & 58.60 & & 20 & 0.89 & 17.80 & 10.520 & & 7.280 \\
\hline $12 \mathrm{H}-6,115$ & 108.35 & 12.06 & 49.80 & 49.15 & & 20 & 0.79 & 15.80 & 7.868 & & 7.932 \\
\hline $12 \mathrm{H}-7,30$ & 109.00 & 12.10 & 25.90 & 26.16 & & 20 & 0.64 & 12.80 & 3.315 & & 9.485 \\
\hline $13 \mathrm{H}-1,70$ & 109.90 & 14.80 & 74.96 & 74.60 & & 20 & 1.02 & 20.40 & 15.292 & & 5.108 \\
\hline $13 \mathrm{H}-1,115$ & 110.35 & 14.95 & 74.09 & 73.89 & & 20 & 0.98 & 19.60 & 14.522 & & 5.078 \\
\hline $13 \mathrm{H}-2,30$ & 111.00 & 15.17 & 78.48 & 77.22 & & 20 & 1.05 & 21.00 & 16.481 & & 4.519 \\
\hline $13 \mathrm{H}-2,70$ & 111.40 & 15.32 & 59.73 & 58.50 & & 20 & 0.80 & 16.00 & 9.557 & & 6.443 \\
\hline $13 \mathrm{H}-2,115$ & 111.85 & 15.47 & 79.87 & 79.30 & & 20 & 1.04 & 20.80 & 16.613 & & 4.187 \\
\hline $13 \mathrm{H}-3,30$ & 112.50 & 15.70 & 87.83 & 87.13 & & 20 & 1.21 & 24.20 & 21.255 & & 2.945 \\
\hline $13 \mathrm{H}-3,70$ & 112.90 & 15.85 & 84.39 & 83.60 & & 20 & 1.19 & 23.80 & 20.085 & & 3.715 \\
\hline $13 \mathrm{H}-3,115$ & 113.35 & 16.02 & 81.82 & 80.63 & & 20 & 1.15 & 23.00 & 18.819 & & 4.181 \\
\hline $13 \mathrm{H}-4,30$ & 114.00 & 16.22 & 74.51 & 74.97 & & 20 & 1.11 & 22.20 & 16.541 & & 5.659 \\
\hline $13 \mathrm{H}-4,70$ & 114.40 & 16.25 & 45.51 & 45.30 & & 20 & 0.71 & 14.20 & 6.462 & & 7.738 \\
\hline $13 \mathrm{H}-4,115$ & 114.85 & 16.28 & 24.25 & 24.90 & & 20 & 0.43 & 8.60 & 2.085 & & 6.514 \\
\hline $13 \mathrm{H}-5,30$ & 115.50 & 16.32 & 87.95 & 88.05 & & 20 & 1.20 & 24.00 & 21.108 & & 2.892 \\
\hline $13 \mathrm{H}-5,70$ & 115.90 & 16.35 & 92.12 & 91.10 & & 20 & 1.12 & 22.40 & 20.635 & & 1.765 \\
\hline $13 \mathrm{H}-6,30$ & 117.00 & 16.41 & 91.48 & 92.30 & & 20 & 1.20 & 24.00 & 21.955 & & 2.045 \\
\hline $14 \mathrm{H}-1,130$ & 120.00 & 16.56 & 46.20 & 44.23 & & 20 & 0.59 & 11.80 & 5.452 & & 6.348 \\
\hline $14 \mathrm{H}-2,30$ & 120.50 & 16.59 & 91.64 & 92.05 & & 20 & 1.10 & 22.00 & 20.161 & & 1.839 \\
\hline $14 \mathrm{H}-2,70$ & 120.90 & 16.62 & & & & 20 & 1.12 & 22.40 & & & \\
\hline $14 \mathrm{H}-2,115$ & 121.35 & 16.65 & 90.49 & 89.63 & & 20 & 1.11 & 22.20 & 20.089 & & 2.111 \\
\hline $14 \mathrm{H}-3,30$ & 122.00 & 16.69 & 92.70 & 91.96 & & 20 & 1.16 & 23.20 & 21.506 & & 1.694 \\
\hline $14 \mathrm{H}-3,70$ & 122.40 & 16.72 & 86.36 & 83.60 & & 20 & 1.05 & 21.00 & 18.136 & & 2.864 \\
\hline $14 \mathrm{H}-3,130$ & 123.00 & 16.76 & 90.95 & 90.21 & & 20 & 1.12 & 22.40 & 20.373 & & 2.027 \\
\hline $14 \mathrm{H}-4,30$ & 123.50 & 16.79 & 94.48 & 93.71 & & 20 & 1.16 & 23.20 & 21.919 & & 1.281 \\
\hline $14 \mathrm{H}-4,70$ & 123.90 & 16.82 & 88.12 & 87.50 & & 20 & 1.06 & 21.20 & 18.681 & & 2.519 \\
\hline $14 \mathrm{H}-4,115$ & 124.35 & 16.85 & 84.27 & 84.88 & & 20 & 1.05 & 21.00 & 17.697 & & 3.303 \\
\hline $14 \mathrm{H}-5,30$ & 125.00 & 16.89 & 81.85 & 76.89 & & 20 & 1.09 & 21.80 & 17.843 & & 3.957 \\
\hline $14 \mathrm{H}-5,70$ & 125.40 & 16.92 & 72.43 & 70.90 & & 20 & 0.96 & 19.20 & 13.907 & & 5.293 \\
\hline $14 \mathrm{H}-5,130$ & 126.00 & 16.95 & 51.65 & 50.73 & & 20 & 0.91 & 18.20 & 9.400 & & 8.800 \\
\hline $14 \mathrm{H}-6,30$ & 126.50 & 16.98 & 69.43 & 65.64 & & 20 & 0.84 & 16.80 & 11.664 & & 5.136 \\
\hline $14 \mathrm{H}-6,70$ & 126.90 & 17.01 & & & & 20 & 0.83 & 16.60 & & & \\
\hline $14 \mathrm{H}-7,30$ & 128.00 & 17.06 & 47.53 & 48.15 & & 20 & 0.72 & 14.40 & 6.844 & & 7.556 \\
\hline $14 \mathrm{H}-7,70$ & 128.40 & 17.08 & 62.03 & 61.20 & & 20 & 0.85 & 17.00 & 10.545 & & 6.455 \\
\hline $15 \mathrm{H}-1,30$ & 128.50 & 17.08 & 67.56 & 67.31 & & 20 & 0.85 & 17.00 & 11.485 & & 5.515 \\
\hline $15 \mathrm{H}-1,70$ & 128.90 & 17.09 & & & & 20 & 0.90 & 18.00 & & & \\
\hline $15 \mathrm{H}-1,115$ & 129.35 & 17.12 & 74.46 & 74.05 & & 20 & 0.90 & 18.00 & 13.403 & & 4.597 \\
\hline $15 \mathrm{H}-2,30$ & 130.00 & 17.15 & 81.91 & 81.97 & & 20 & 1.00 & 20.00 & 16.382 & & 3.618 \\
\hline $15 \mathrm{H}-2,87$ & 130.57 & 17.17 & 72.19 & 71.30 & & 20 & 1.03 & 20.60 & 14.871 & & 5.729 \\
\hline $15 \mathrm{H}-2,115$ & 130.85 & 17.20 & 70.85 & 90.71 & & 20 & 0.96 & 19.20 & 13.603 & & 5.597 \\
\hline $15 \mathrm{H}-3,30$ & 131.50 & 17.24 & 71.88 & 61.64 & & 20 & 0.93 & 18.60 & 13.370 & & 5.230 \\
\hline $15 \mathrm{H}-3,70$ & 131.90 & 17.27 & 74.06 & 74.10 & & 20 & 0.94 & 18.80 & 13.923 & & 4.877 \\
\hline $15 \mathrm{H}-3,115$ & 132.35 & 17.30 & 77.77 & 75.97 & 3.5 & 20 & 0.97 & 19.40 & 15.087 & 0.679 & 4.313 \\
\hline $15 \mathrm{H}-4,30$ & 133.00 & 17.35 & 85.06 & 93.55 & 5.4 & 20 & 0.98 & 19.60 & 16.672 & 1.058 & 2.928 \\
\hline $15 \mathrm{H}-4,70$ & 133.40 & 17.38 & 84.76 & 84.60 & & 20 & 1.00 & 20.00 & 16.952 & & 3.048 \\
\hline $15 \mathrm{H}-4,115$ & 133.85 & 17.41 & 88.99 & & & 20 & 1.12 & 22.40 & 19.934 & & 2.466 \\
\hline $15 \mathrm{H}-4,30$ & 134.50 & 17.45 & 86.84 & & & 20 & 0.99 & 19.80 & 17.194 & & 2.606 \\
\hline $15 \mathrm{H}-5,70$ & 134.90 & 17.48 & 85.35 & 84.90 & & 20 & 0.97 & 19.40 & 16.558 & & 2.842 \\
\hline $15 \mathrm{H}-5,115$ & 135.35 & 17.51 & 88.97 & & & 20 & 1.03 & 20.60 & 18.328 & & 2.272 \\
\hline
\end{tabular}


Appendix A (continued).

Absolute Accumulation Rates, Site 751.

\begin{tabular}{|c|c|c|c|c|c|c|c|c|c|c|c|}
\hline $\begin{array}{l}\text { Core, section, } \\
\text { interval (top) }\end{array}$ & $\begin{array}{l}\text { Depth } \\
\text { (mbsf) }\end{array}$ & $\begin{array}{c}\text { Age } \\
(\mathrm{m} . \mathrm{y} .)\end{array}$ & $\begin{array}{l}\mathrm{CaCO}_{3} \\
\text { (shore) }\end{array}$ & $\begin{array}{c}\mathrm{CaCO}_{3} \\
\text { (ship) }\end{array}$ & $\mathrm{SiO}_{2}$ & LSR & DBD & $\begin{array}{l}\text { Bulk } \\
\text { AAR }\end{array}$ & $\begin{array}{c}\mathrm{CaCO}_{3} \\
\mathrm{AAR}^{-}\end{array}$ & $\begin{array}{l}\mathrm{SiO}_{2} \\
\mathrm{AAR}\end{array}$ & $\begin{array}{c}\text { Non- } \mathrm{CaCO}_{3} \\
\text { AAR }\end{array}$ \\
\hline $15 \mathrm{H}-6,30$ & 136.00 & 17.55 & 88.67 & & & 20 & 1.08 & 21.60 & 19.153 & & 2.447 \\
\hline $15 \mathrm{H}-6,70$ & 136.40 & 17.58 & 86.13 & 85.40 & & 20 & 1.01 & 20.20 & 17.398 & & 2.802 \\
\hline $15 \mathrm{H}-6,115$ & 136.85 & 17.61 & 89.30 & & & 20 & 1.03 & 20.60 & 18.396 & & 2.204 \\
\hline $16 \mathrm{H}-1,30$ & 138.00 & 17.69 & 87.63 & & & 20 & 1.01 & 20.20 & 17.701 & & 2.499 \\
\hline $16 \mathrm{H}-1,70$ & 138.40 & 17.72 & 87.14 & 86.00 & & 20 & 1.00 & 20.00 & 17.428 & & 2.572 \\
\hline $16 \mathrm{H}-1,115$ & 138.85 & 17.75 & 85.72 & & & 20 & 0.95 & 19.00 & 16.287 & & 2.713 \\
\hline $16 \mathrm{H}-2,30$ & 139.50 & 17.79 & 84.53 & & & 20 & 1.01 & 20.20 & 17.075 & & 3.125 \\
\hline $16 \mathrm{H}-2,70$ & 139.90 & 17.82 & 86.77 & 85.60 & & 20 & 0.93 & 18.60 & 16.139 & & 2.461 \\
\hline $16 \mathrm{H}-2,115$ & 140.35 & 17.85 & 90.39 & & & 20 & 1.05 & 21.00 & 18.982 & & 2.018 \\
\hline $16 \mathrm{H}-3,30$ & 141.00 & 17.89 & 91.11 & & & 20 & 1.05 & 21.00 & 19.133 & & 1.867 \\
\hline $16 \mathrm{H}-3,70$ & 141.40 & 17.92 & 92.44 & 91.80 & & 20 & 1.07 & 21.40 & 19.782 & & 1.618 \\
\hline $16 \mathrm{H}-3,115$ & 141.85 & 17.95 & 90.69 & & & 20 & 1.07 & 21.40 & 19.408 & & 1.992 \\
\hline $16 \mathrm{H}-4,30$ & 142.50 & 17.99 & 92.61 & & & 20 & 1.08 & 21.60 & 20.004 & & 1.596 \\
\hline $16 \mathrm{H}-4,70$ & 142.90 & 18.03 & 90.99 & 90.20 & & 20 & 1.07 & 21.40 & 19.472 & & 1.928 \\
\hline $16 \mathrm{H}-4,115$ & 143.35 & 18.06 & 91.78 & & & 20 & 1.11 & 22.20 & 20.375 & & 1.825 \\
\hline $16 \mathrm{H}-5,30$ & 144.00 & 18.10 & 92.34 & & & 20 & 1.10 & 22.00 & 20.315 & & 1.685 \\
\hline $16 \mathrm{H}-5,70$ & 144.40 & 18.13 & 91.15 & 91.00 & & 20 & 1.00 & 20.00 & 18.230 & & 1.770 \\
\hline $16 \mathrm{H}-5,115$ & 144.85 & 18.16 & 91.72 & & & 20 & 1.08 & 21.60 & 19.812 & & 1.788 \\
\hline $16 \mathrm{H}-6,30$ & 145.50 & 18.20 & 87.59 & & & 20 & 1.07 & 21.40 & 18.744 & & 2.656 \\
\hline $16 \mathrm{H}-6,70$ & 145.90 & 18.23 & 88.44 & 87.60 & & 20 & 1.05 & 21.00 & 18.572 & & 2.428 \\
\hline $16 \mathrm{H}-6,115$ & 146.35 & 18.26 & 88.10 & & & 20 & 1.09 & 21.80 & 19.206 & & 2.594 \\
\hline $16 \mathrm{H}-7,30$ & 147.00 & 18.30 & 88.39 & & & 20 & 1.04 & 20.80 & 18.385 & & 2.415 \\
\hline $16 \mathrm{H}-7,70$ & 147.40 & 18.33 & 90.04 & & & 20 & 1.06 & 21.20 & 19.088 & & 2.112 \\
\hline $17 \mathrm{H}-1,30$ & 147.50 & 18.34 & 90.57 & & & 20 & 1.06 & 21.20 & 19.201 & & 1.999 \\
\hline $17 \mathrm{H}-2,30$ & 149.00 & 18.42 & 91.29 & & & 20 & 1.09 & 21.80 & 19.901 & & 1.899 \\
\hline $17 \mathrm{H}-2,70$ & 149.40 & 18.45 & 89.97 & 88.10 & & 20 & 1.03 & 20.60 & 18.534 & & 2.066 \\
\hline $17 \mathrm{H}-2,115$ & 149.85 & 18.48 & 88.34 & & & 20 & 1.06 & 21.20 & 18.728 & & 2.472 \\
\hline $17 \mathrm{H}-3,30$ & 150.50 & 18.52 & 82.99 & & & 20 & 0.93 & 18.60 & 15.436 & & 3.164 \\
\hline $17 \mathrm{H}-3,70$ & 150.90 & 18.56 & 84.24 & & & 20 & 0.98 & 19.60 & 16.511 & & 3.089 \\
\hline $17 \mathrm{H}-3,115$ & 151.35 & 18.59 & 87.51 & & & 20 & 0.96 & 19.20 & 16.802 & & 2.398 \\
\hline $17 \mathrm{H}-4,115$ & 152.85 & 18.67 & 82.02 & & & 20 & 0.86 & 17.20 & 14.107 & & 3.093 \\
\hline $17 \mathrm{H}-5,30$ & 153.50 & 18.71 & 87.91 & & & 20 & 1.00 & 20.00 & 17.582 & & 2.418 \\
\hline $17 \mathrm{H}-5,70$ & 153.90 & 18.74 & 89.84 & 88.40 & & 20 & 1.03 & 20.60 & 18.507 & & 2.093 \\
\hline $17 \mathrm{H}-6,30$ & 155.00 & 18.81 & 76.02 & & & 20 & 0.90 & 18.00 & 13.684 & & 4.316 \\
\hline $17 \mathrm{H}-6,70$ & 155.40 & 18.84 & 82.22 & 80.90 & & 20 & 0.94 & 18.80 & 15.457 & & 3.343 \\
\hline $17 \mathrm{H}-6,115$ & 155.85 & 18.87 & 66.75 & & & 20 & 0.95 & 19.00 & 12.682 & & 6.318 \\
\hline $17 \mathrm{H}-7,30$ & 156.50 & 18.91 & 79.58 & & & 20 & 0.99 & 19.80 & 15.757 & & 4.043 \\
\hline $18 \mathrm{H}-1,30$ & 157.00 & 18.95 & 77.12 & & & 20 & 0.92 & 18.40 & 14.190 & & 4.210 \\
\hline $18 \mathrm{H}-1,70$ & 157.40 & 18.98 & 79.88 & 78.10 & & 20 & 0.90 & 18.00 & 14.378 & & 3.622 \\
\hline $18 \mathrm{H}-1,115$ & 157.85 & 19.01 & 83.56 & & & 20 & 0.90 & 18.00 & 15.041 & & 2.959 \\
\hline $18 \mathrm{H}-2,30$ & 158.50 & 19.04 & 78.43 & & & 20 & 0.90 & 18.00 & 14.117 & & 3.883 \\
\hline $18 \mathrm{H}-2,70$ & 158.90 & 19.07 & 84.37 & 84.10 & & 20 & 0.93 & 18.60 & 15.693 & & 2.907 \\
\hline $18 \mathrm{H}-2,115$ & 159.35 & 19.10 & 82.40 & & & 20 & 0.99 & 19.80 & 16.315 & & 3.485 \\
\hline $18 \mathrm{H}-3,30$ & 160.00 & 19.13 & 87.47 & & & 20 & 0.99 & 19.80 & 17.319 & & 2.481 \\
\hline $18 \mathrm{H}-3,70$ & 160.40 & 19.16 & 93.18 & 92.90 & & 20 & 1.08 & 21.60 & 20.127 & & 1.473 \\
\hline $18 \mathrm{H}-3,115$ & 160.85 & 19.19 & 78.38 & & 7.3 & 20 & 0.85 & 17.00 & 13.325 & 1.241 & 3.675 \\
\hline $18 \mathrm{H}-4,30$ & 161.50 & 19.22 & 84.63 & & 6.9 & 20 & 1.00 & 20.00 & 16.926 & 1.380 & 3.074 \\
\hline $18 \mathrm{H}-4,70$ & 161.90 & 19.25 & 80.28 & 80.90 & & 20 & 0.99 & 19.80 & 15.895 & & 3.905 \\
\hline $18 \mathrm{H}-4,115$ & 162.35 & 19.28 & 86.19 & & & 20 & 1.02 & 20.40 & 17.583 & & 2.817 \\
\hline $18 \mathrm{H}-5,30$ & 163.00 & 19.32 & 88.45 & & & 20 & 1.01 & 20.20 & 17.867 & & 2.333 \\
\hline $18 \mathrm{H}-5,70$ & 163.40 & 19.35 & 70.25 & & & 20 & 0.77 & 15.40 & 10.819 & & 4.581 \\
\hline $18 \mathrm{H}-5,115$ & 163.85 & 19.38 & 85.76 & & & 20 & 1.01 & 20.20 & 17.324 & & 2.876 \\
\hline $18 \mathrm{H}-6,30$ & 164.50 & 19.50 & 75.92 & & & 20 & 0.88 & 17.60 & 13.362 & & 4.238 \\
\hline
\end{tabular}

Notes: The table given above contains the data used to calculate the accumulation rates for this study. Interval (top) = interval $(\mathrm{cm})$ from top of core section; Depth (mbsf) = sub-bottom depth; Age (m.y.) = age from shipboard biostratigraphy (in Ma); $\mathrm{CaCO}_{3}$ (shore) $=$ shore-based measurement of percentage $\mathrm{CaCO}_{3} ; \mathrm{CaCO}_{3}$ (ship) = shipboard measurement of percentage $\mathrm{CaCO}_{3} ; \mathrm{SiO}_{2}=w t \%$ biogenic silica (determined by $\mathrm{D}$. DeMaster, NCSU); LSR = linear sedimentation rate (from shipboard biostratigraphy); $\mathrm{DBD}=$ dry-bulk density (in $\mathrm{g} / \mathrm{cm}^{3}$ ); Bulk AAR = bulk absolute accumulation rate (in $\mathrm{g} / \mathrm{m}^{2} / \mathrm{k} . \mathrm{y}$. or $\mathrm{g} / \mathrm{mm}^{2} / \mathrm{k} . \mathrm{y}$.); $\mathrm{CaCO}_{3} \mathrm{AAR}=$ absolute accumulation rate of carbonate (same units as Bulk $\mathrm{AAR}$ ); $\mathrm{SiO} 2 \mathrm{AAR}=$ absolute accumulation rate of biogenic silica (same units as Bulk $\mathrm{AAR}$ ); Non- $\mathrm{CaCO}_{3} \mathrm{AAR}=$ noncarbonate absolute accumulation rate (same units as Bulk AAR). 


\section{APPENDIX B}

Microfabric Analysis of SEM Samples

1. Sample $120-751 \mathrm{~A}-13 \mathrm{H}-6,30-32 \mathrm{~cm}$ (117.0 mbsf)

Age: middle Miocene (14-15 Ma)

Microfabric: The SEM revealed this sample to be characterized by well-preserved, intact, scattered foraminifers surrounded by a matrix of intact nannofossils and disassociated nannofossil crystallites. Only a few severely corroded radiolarian fragments are present and completely filled with the matrix material. We observed a minimum of open pore space, as interparticle space was filled, and pores on microfossil tests, where present, were closed or filled.

\section{Sample 120-751A-12H-4, 115-117 cm (105.4 mbsf)}

Age: middle Miocene (12-13 Ma)

Microfabric: The SEM revealed this sample to be similar to the underlying sample, different only in that siliceous microfossils are slightly more abundant and extremely corroded; and the nannofossils are somewhat corroded and disassociated into crystallites. Only a very few diatom fragments are present in the matrix of predominantly nannofossils and nannofossil fragments. Radiolarians, where present, are completely filled with matrix material, and the pores of radiolarian and diatom tests are filled as well. Few large skeletons or skeletal fragments are present in this sample.

3. Samples 120-751A-8H-5, 70-72 cm (68.4 mbsf), and -8H-5, 30-32 $\mathrm{cm}(68.0 \mathrm{mbsf})$

Age: late Miocene (9-10 Ma)

Microfabric: The SEM showed these samples to be similar, characterized by concentrations of robust centric diatom valves, heavily silicified diatom girdle bands, and the heavily silicified central part of the valve. Some elongate pennate diatoms are present. The larger skeletal elements are in contact with one another, and in general there appears to be comparatively little matrix material. Where present, the matrix consists of diatom and nannofossil fragments; few intact nannofossils are present. Both silica and calcite appear to be corroded. Overgrowths are present on some siliceous skeletons, and pores on some of the siliceous skeletons are filled, although pore space is generally open on the robust diatom valves. Some diatom valves and girdle bands appear to be articulated, and some girdle bands appear to be nested. The centric diatom valves show an indication of preferred orientation, and many appear to be lying flat when viewed from above. Some of the centric valves have become broken into smaller fragments, possibly as a result of dissolution.
4. Samples $120-751 \mathrm{~A}-6 \mathrm{H}-3,70-72 \mathrm{~cm}(46.4 \mathrm{mbsf})$ and $-6 \mathrm{H}-1,70-72$ $\mathrm{cm}$ (43.4 mbsf)

Age: late Miocene (5-6 Ma)

Microfabric: SEM analysis showed the siliceous material in these samples to be highly corroded; few pennate diatoms are present, although the heavily silicified elements of pennate tests are apparently concentrated. Some articulated robust centric diatoms and girdle bands are present. Pore spaces generally are filled with matrix material, which consists of nannofossils (intact and disassociated crystallites) and centric and pennate diatom fragments.

5. Sample 120-751A-5H-5, 70-72 cm (39.9 mbsf)

Age: early Pliocene (to late Miocene?) (4.5-6 Ma)

Microfabric: The SEM revealed that this sample was different from all the others in that the siliceous skeletal remains were pervasively coated; EDAX analysis indicated that the coating material is entirely siliceous (? opal-A'). Few elongate pennate diatoms are present; large valves are scattered in the matrix of siliceous fragments. Pores on siliceous skeletons are generally filled by the matrix and/or coating material.

6. Samples 120-751A-4H-6, 30-32 cm (31.5 mbsf) and -4H-4, 67-69 $\mathrm{cm}$ (28.9 mbsf)

Age: early Pliocene (4-5 Ma)

Microfabric: The SEM showed these samples to be composed predominantly of elongate, essentially intact pennate diatoms; although there is evidence of slight dissolution, the surfaces of these tests are comparatively pristine. In places the preferred orientation of the long axes of these tests is apparent. There are isolated instances of actual laminae of clustered, oriented elongate pennate diatom valves. The matrix is composed of fragments of diatoms; some centric valves appear to be disassociating into smaller fragments in place. Radiolarians appear to be clustered in the diatom debris; nassellarian radiolarian tests, open at one end, are generally filled with matrix material finer grained than that surrounding the test. Large skeletal fragments are scattered in the matrix and are not generally in contact (even where clustered, as with the radiolarians). Some centric diatoms have two valves and the girdle band articulated. Where present, foraminifers are corroded. The lower of these two samples is distinguished from the upper by some surface corrosion of siliceous material, some breakage of delicate skeletal elements (e.g., spines), more abundant silicoflagellates, and shorter pennate valves (although some elongate valves are present). 


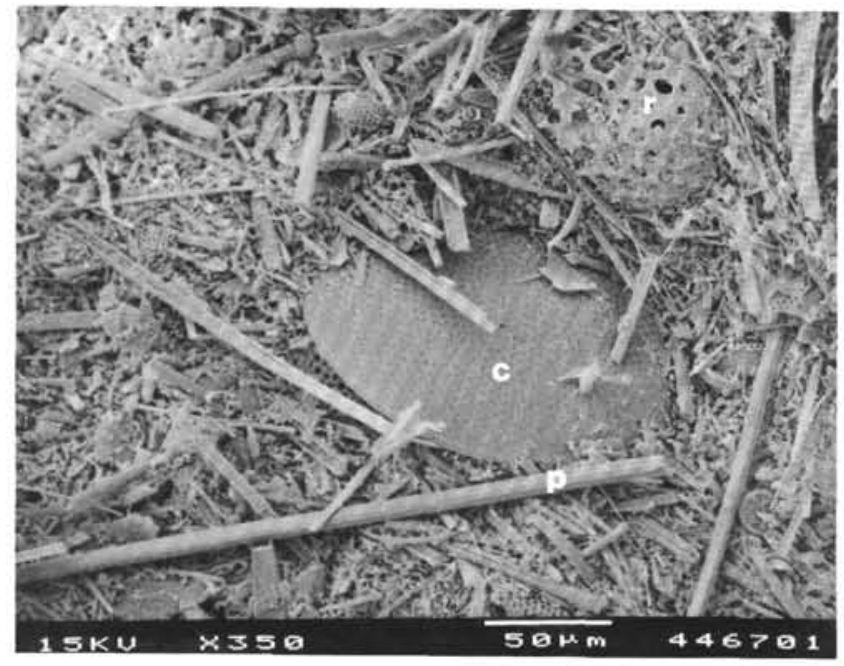

1

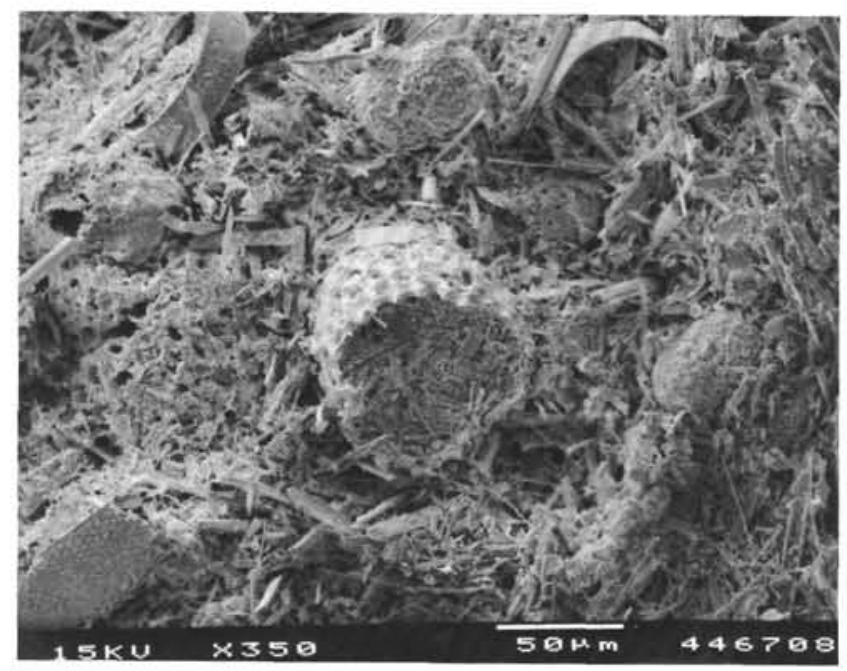

2

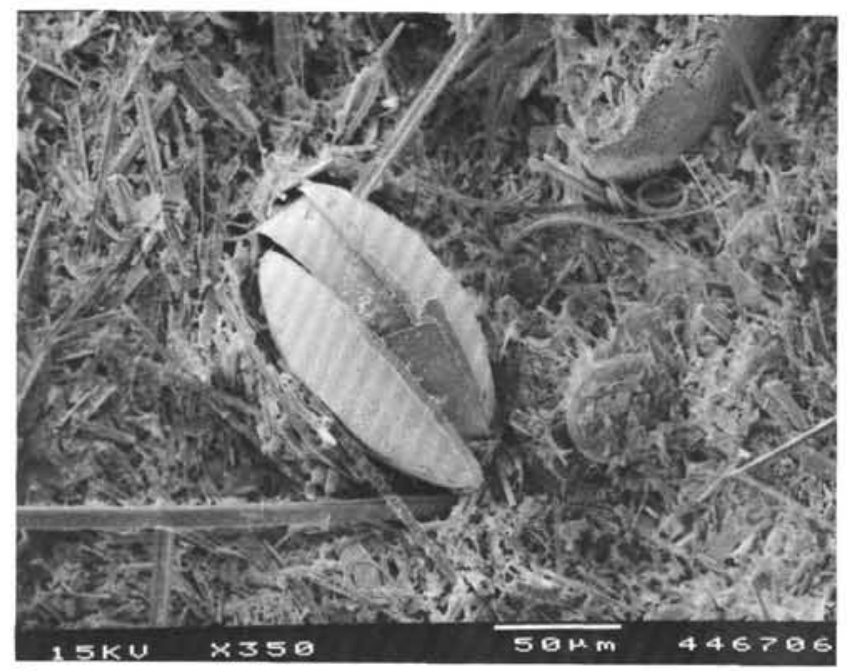

3

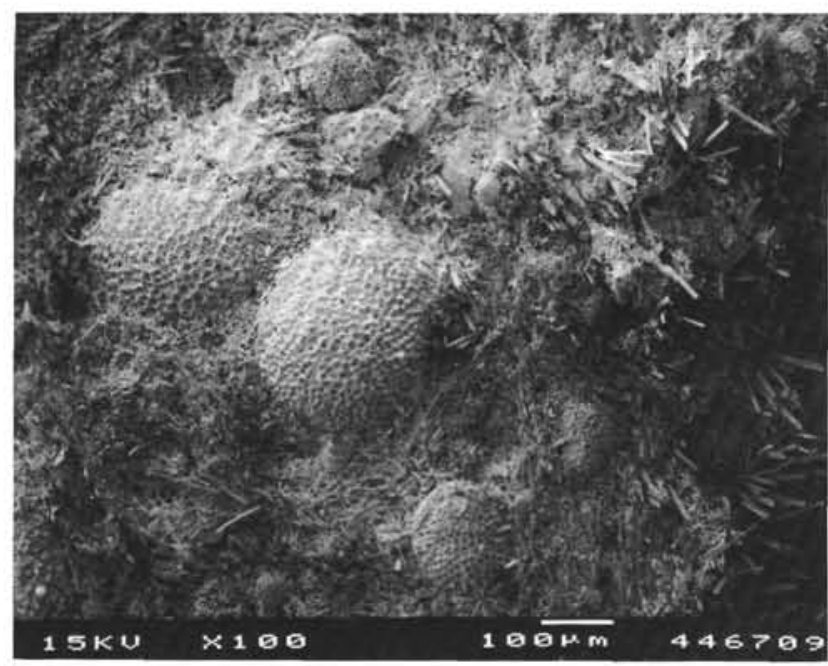

4

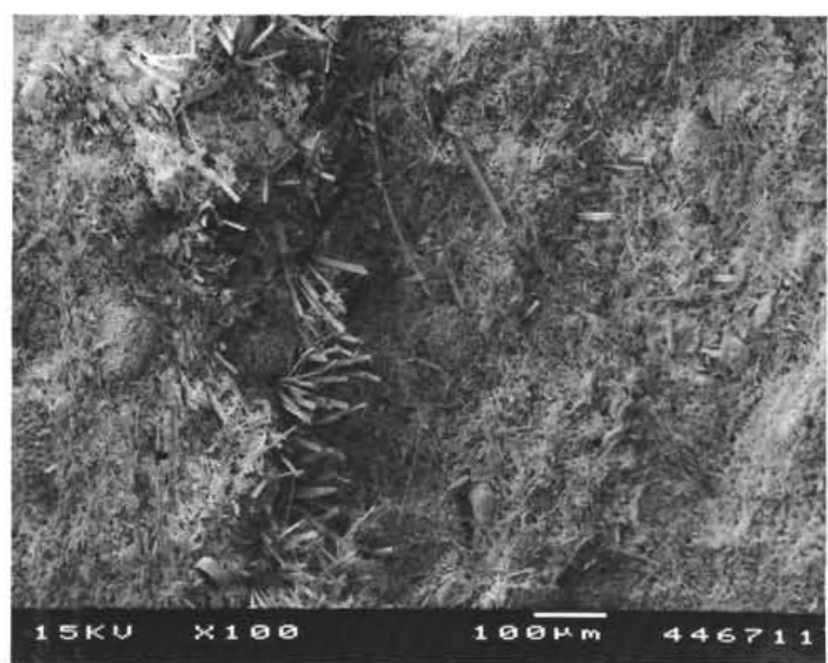

5

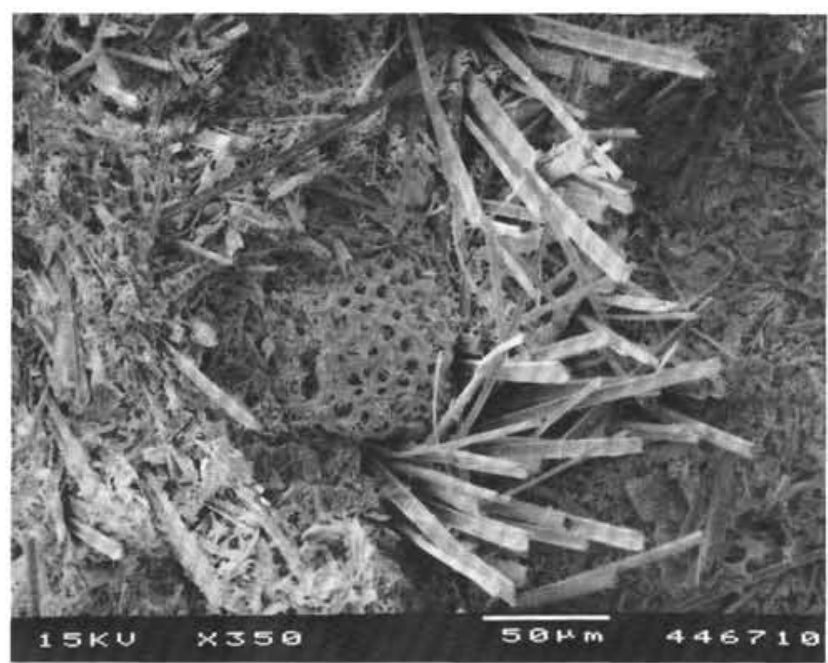

6

Plate 1. Scanning electron photomicrographs of Sample 120-751A-4H-4, 67-69 cm (Unit I). This sample represents the most highly biosiliceous interval of Hole 751A (as does Sample 120-751A-4H-6, 30-32 cm, shown in Plate 2). 1. Centric diatom valve (c) and radiolarian (r), along with large, elongate pennate diatom valves (p) supported by matrix of pennate diatom fragments. 2. Slightly corroded nassellarian radiolarian skeleton (center) in a matrix predominantly composed of pennate diatom fragments; note that material inside radiolarian is finer than the surrounding matrix. 3. Articulated centric diatom valves (center) and girdle band. 4. Spumellarian radiolarians (left-hand side); pennate diatom valves (right-hand side) appear to show preferred orientation along the vertical axis of the photo (= bedding direction?). 5, 6. Enlarged detail of aligned pennate diatom valves shown in Figure 4. 


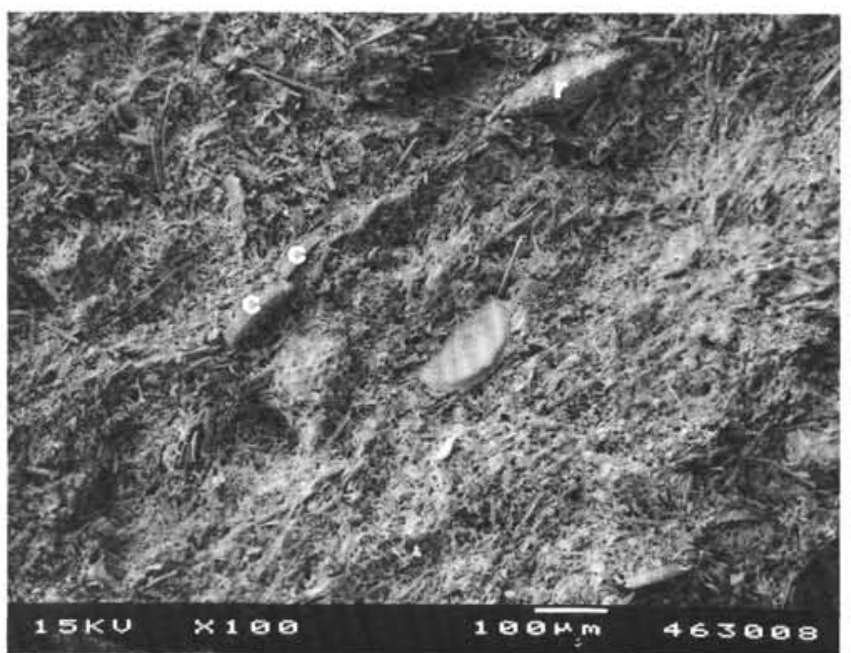

1

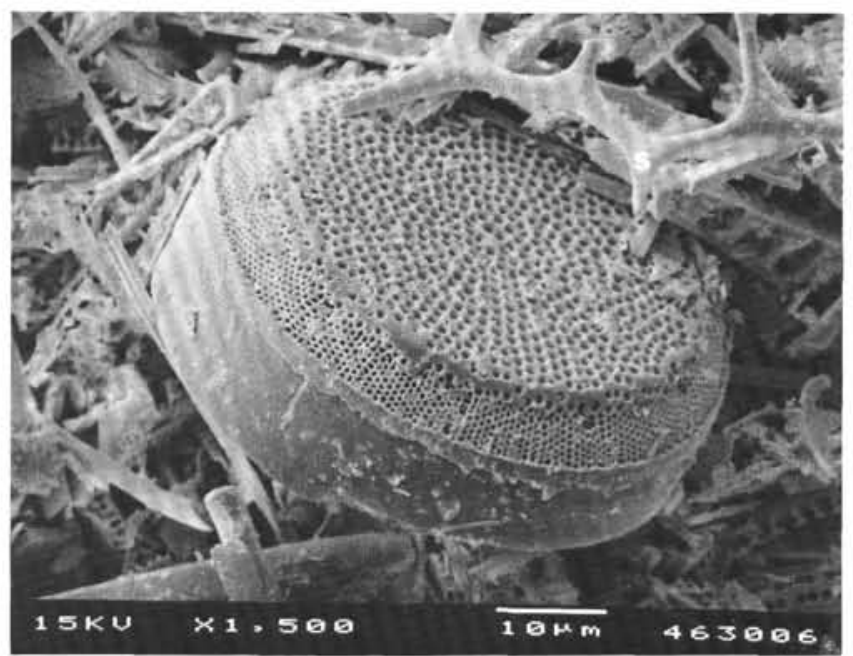

2

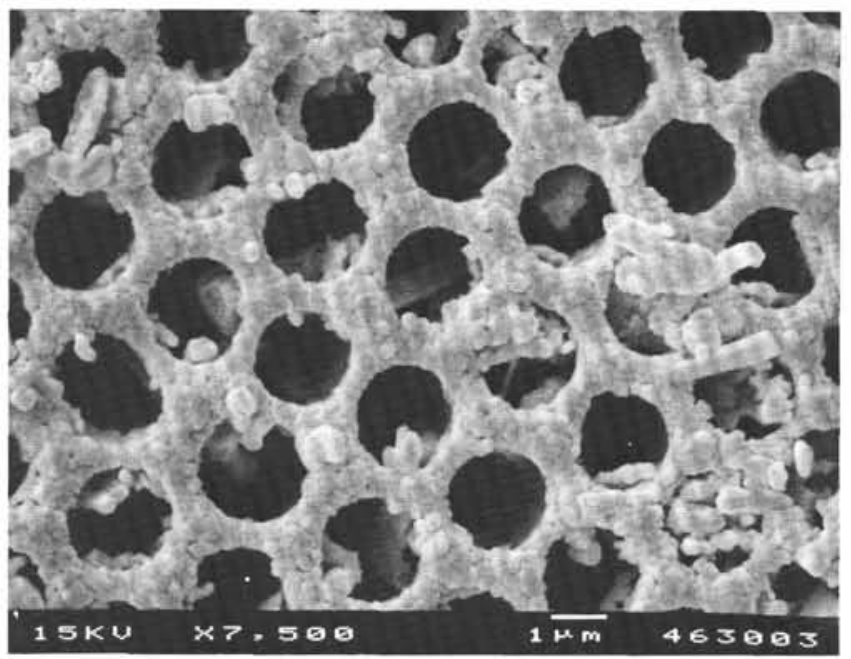

3

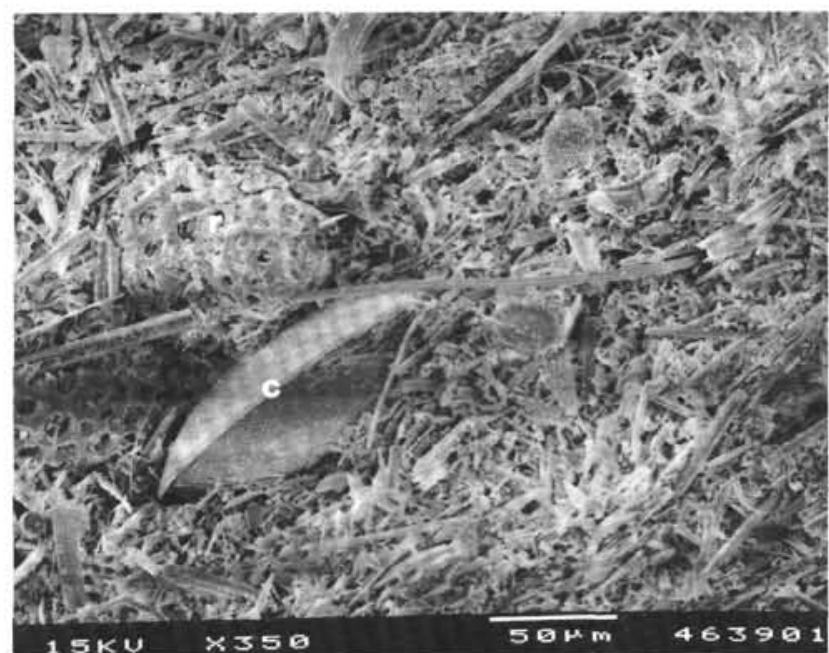

4

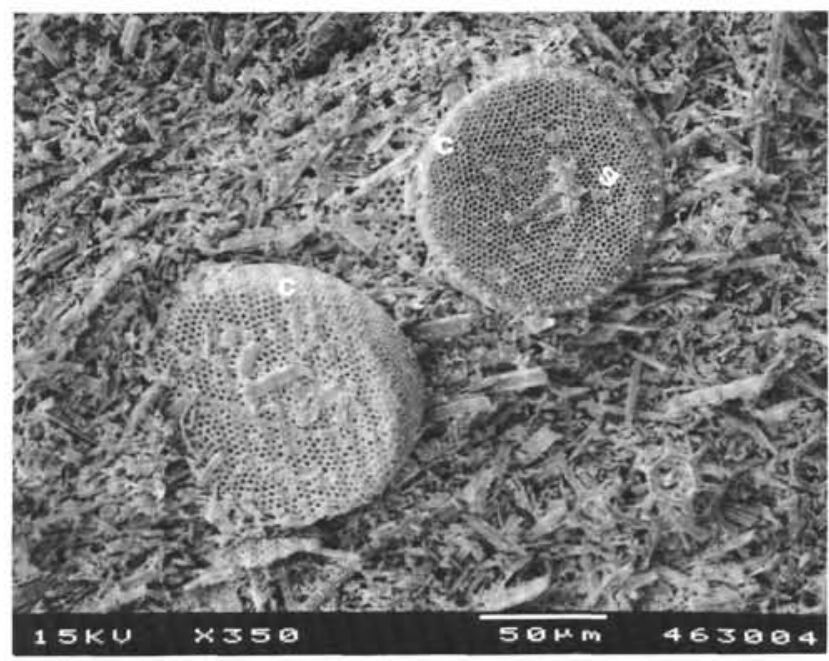

5

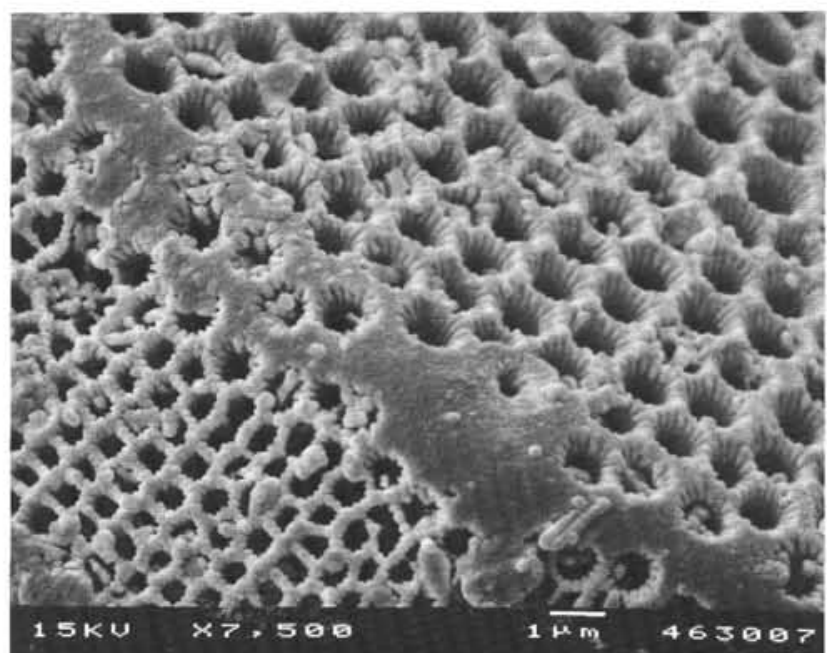

6

Plate 2. Scanning electron photomicrographs of Sample 120-751A-4H-6, 30-32 cm (Unit I). This sample (along with Sample 120-751A-4H-4, 67-69 cm, shown in Plate 1) represents the most highly biosiliceous interval of Hole 751A. 1. Siliceous ooze consisting primarily of pennate diatom fragments; note preferred orientation suggested by alignment of centric diatom valves (c) and spongodiscid radiolarians (r) at upper left. 2. Centric diatom valve and girdle band (center) in contact with broken silicoflagellate (s). 3. Detail of Figure 2, showing pore structure and fairly well preserved silica. 4. Articulated centric diatom valve (c) and nassellarian radiolarian (r) in matrix of pennate diatom fragments and silicoflagellates. 5. Centric diatom valves (c) in matrix of pennate diatom fragments and silicoflagellates. 6. Detail of a centric diatom valve showing silica to be slightly corroded (i.e., surface layer removed?); pore spaces are mostly open. 


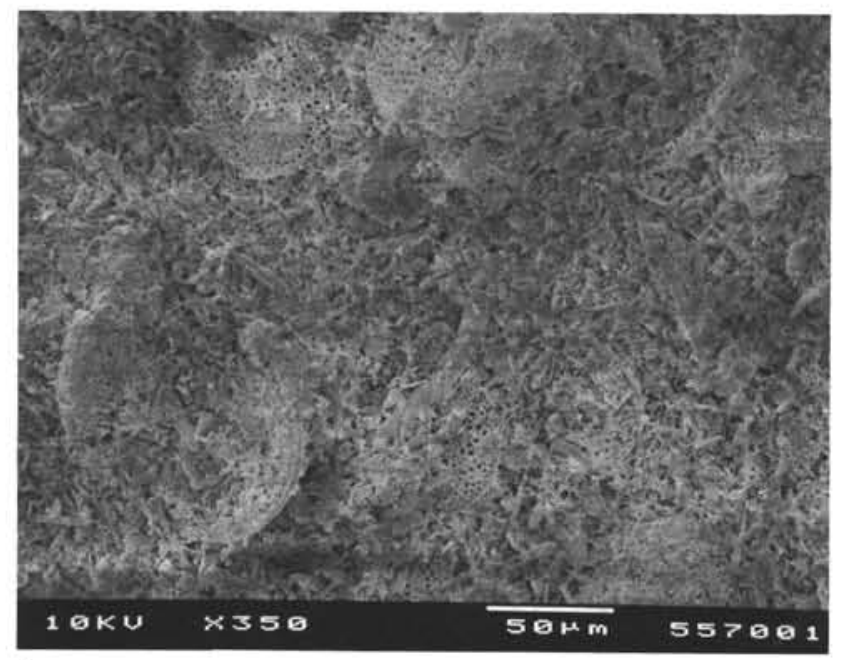

1

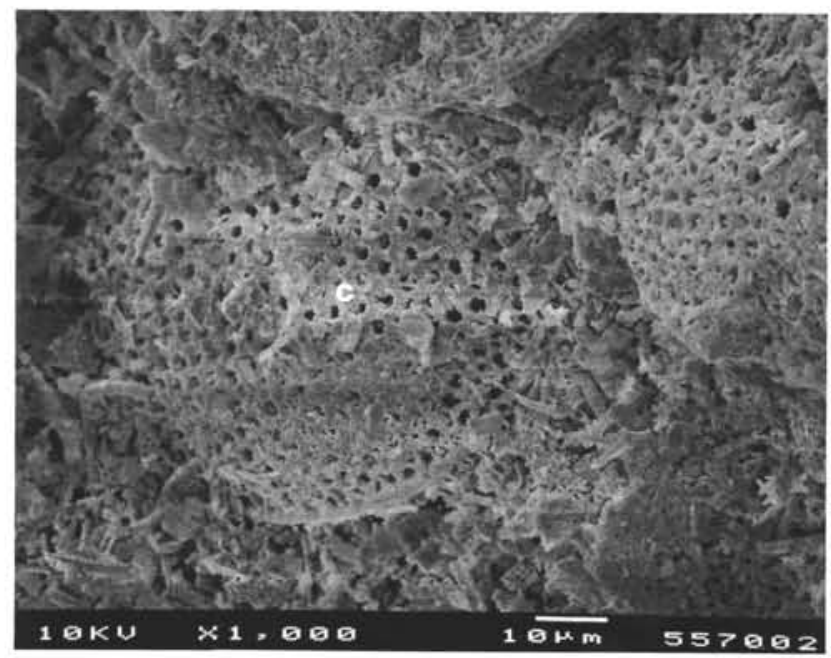

2

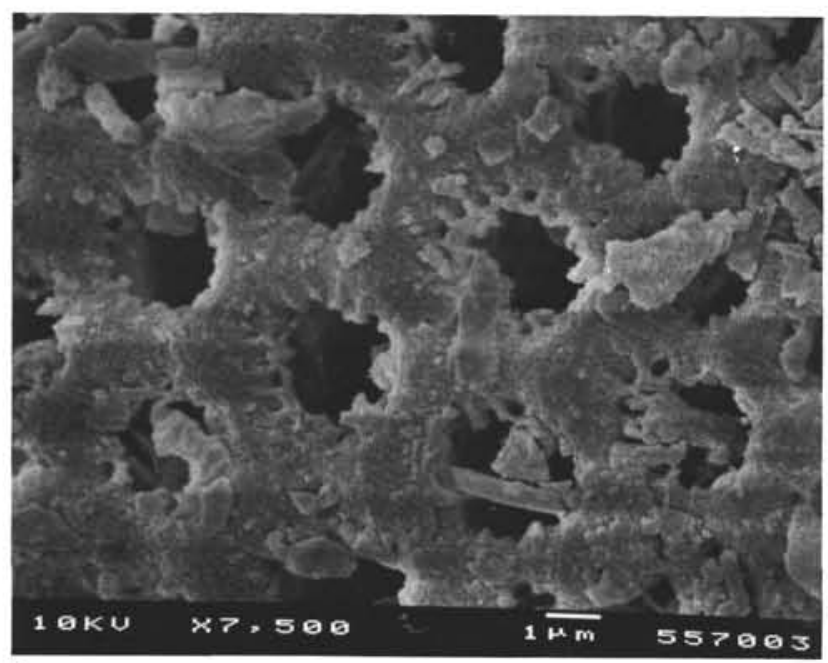

3

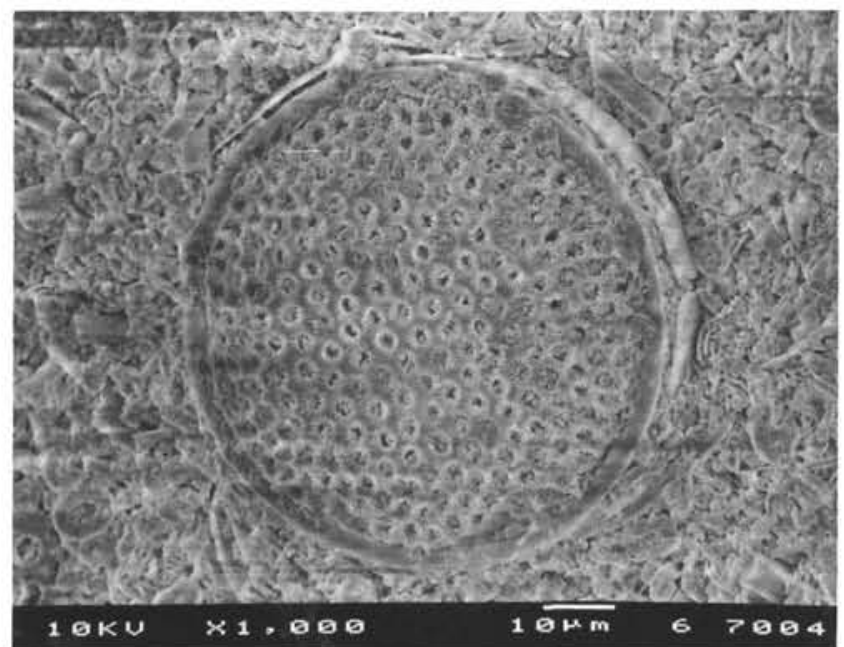

4

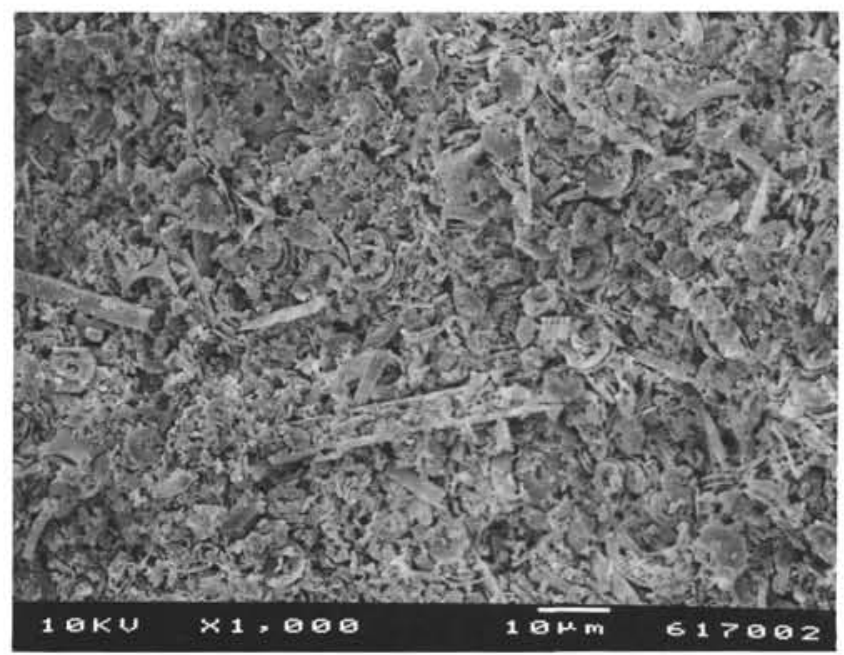

5

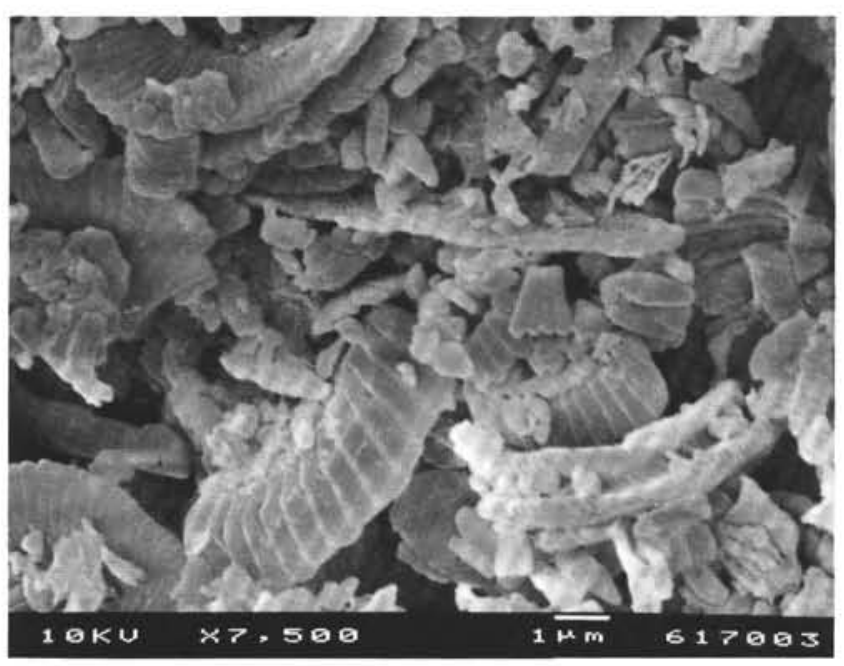

6

Plate 3. 1-3. Scanning electron photomicrographs of Sample 120-751A-5H-5, 70-72 cm (Unit I), $\sim 20 \mathrm{~cm}$ above the major hiatus at $40.1 \mathrm{mbsf}$. (1) Siliceous ooze composed of centric diatom valves and pennate diatom fragments; note authigenic overgrowths and closure of pore spaces. (2) Centric diatom valve (c) surrounded by matrix of siliceous fragments; note that some pores are filled with siliceous debris. (3) Detail of centric diatom in Figure 2 showing authigenic overgrowths; note that some pore ornamentation is unobscured. 4-6. Sample 120-751A-6H-1, 70-72 cm, mixed siliceous-calcareous ooze, comparatively more calcareous (Unit II). (4) Centric diatom valve (center) with girdle band in growth position (although broken) surrounded by a matrix of nannofossils and nannofossil crystallites and pennate diatom fragments; note that pores of diatom are largely blocked by matrix elements. (5) Detail of matrix; note that siliceous elements are typically corroded. (6) Further detail of matrix in Figure 5 . 


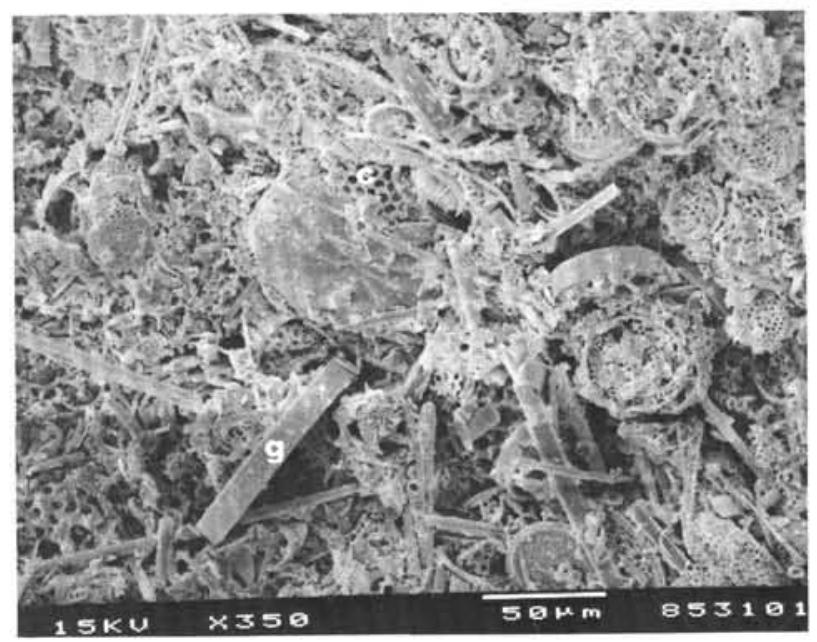

1

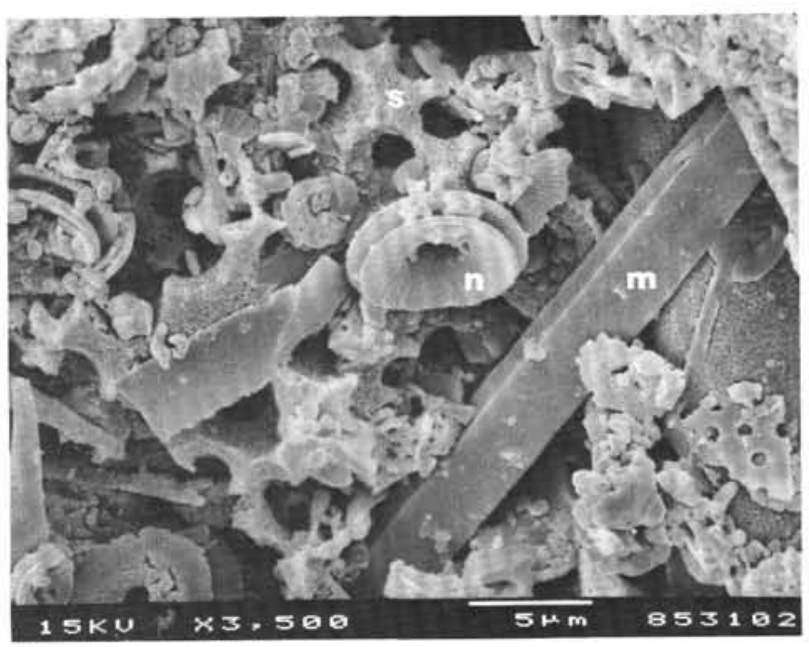

2

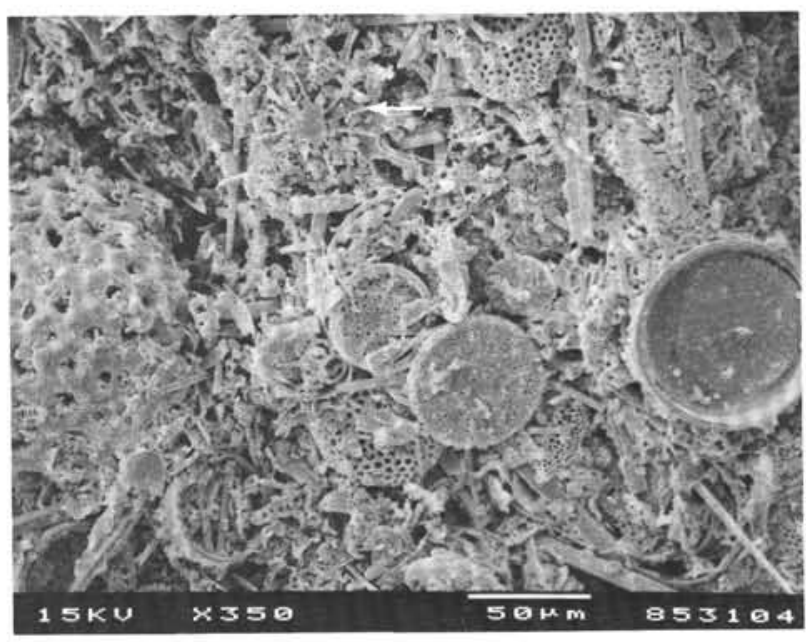

3

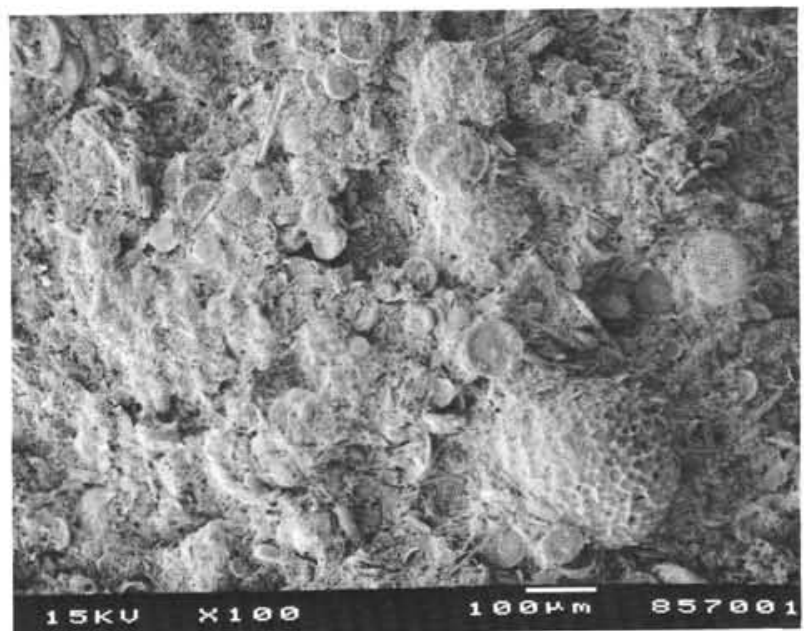

4

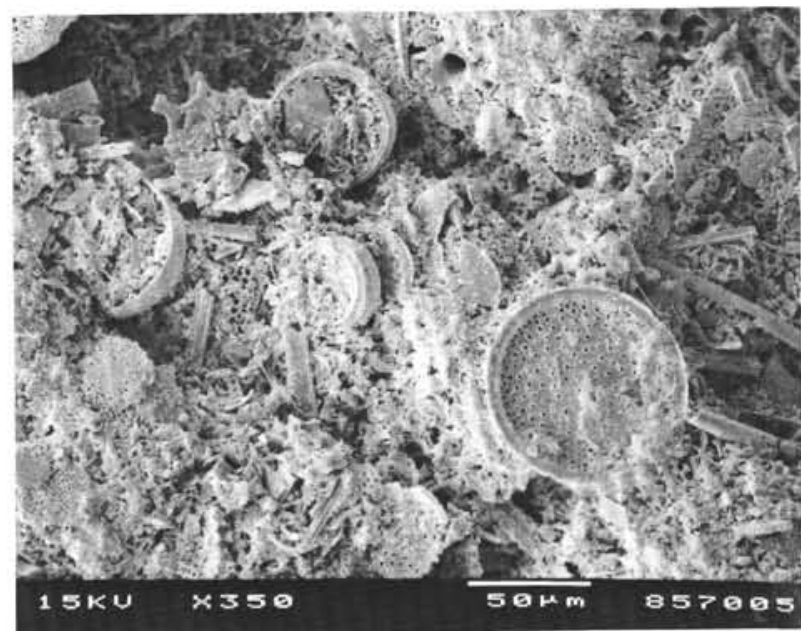

5

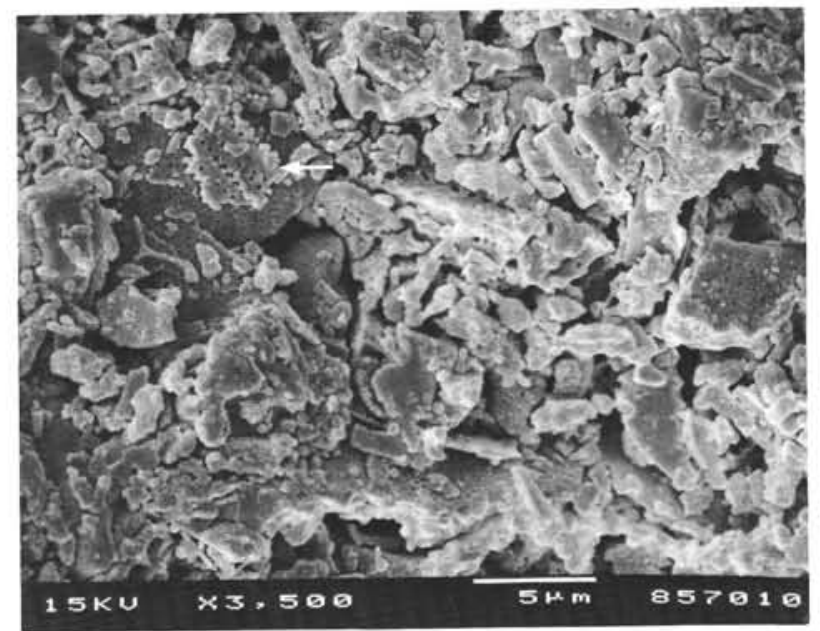

6

Plate 4. 1-3. Scanning electron photomicrographs of Sample 120-751A-8H-5, 30-32 cm, mixed siliceous-calcareous ooze, comparatively more siliceous (Unit II). (1) Large skeletal elements, which typically are in contact rather than being supported by the matrix, include centric diatoms (c), centric diatom girdle bands (g), and pennate diatoms; the matrix consists of centric and pennate diatom fragments and nannofossils. (2) Detail of area immediately to the left of center in Figure 1; note good preservation of nannofossils (n) and corrosion of siliceous fragment(s); note also detrital (?) mineral grain $(\mathrm{m})$. (3) Robust, heavily silicified diatom valves and girdle bands showing evidence of corrosion; note specimen to upper left of center (arrow) reduced to the ornamented part of the valve; silicoflagellates and nannofossils are present in the matrix. 4-6. Sample $120-751 \mathrm{~A}-8 \mathrm{H}-5,70-72 \mathrm{~cm}$, mixed siliceous-calcareous ooze, comparatively more siliceous (Unit II). (4) Robust centric diatom valves, having possible preferred orientation (flat lying in plan view). (5) Heavily silicified centric diatom valves showing evidence of corrosion. (6) Detail of matrix, which consists of nannofossil and diatom fragments; note centric diatom valve disassociating into fragments (arrow). 


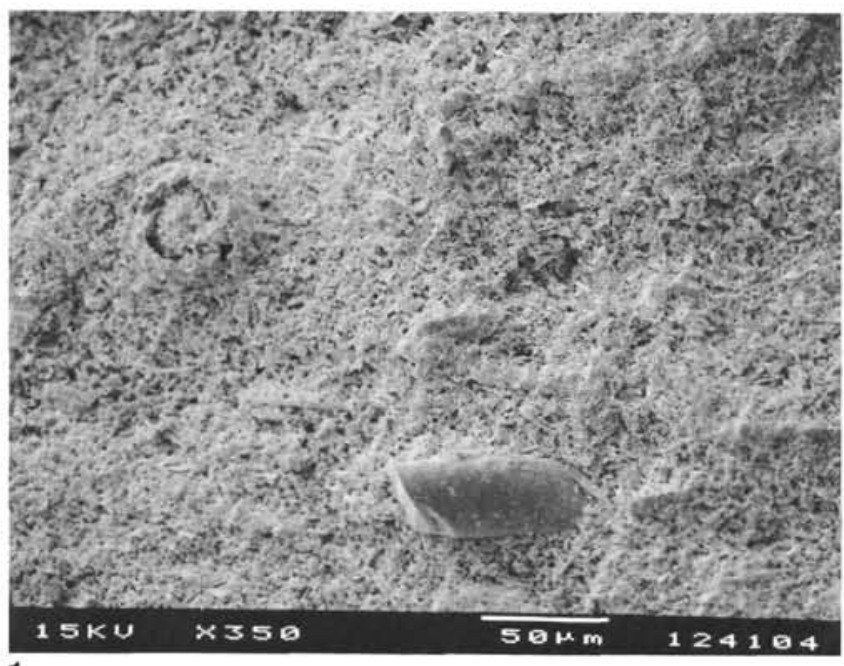

1

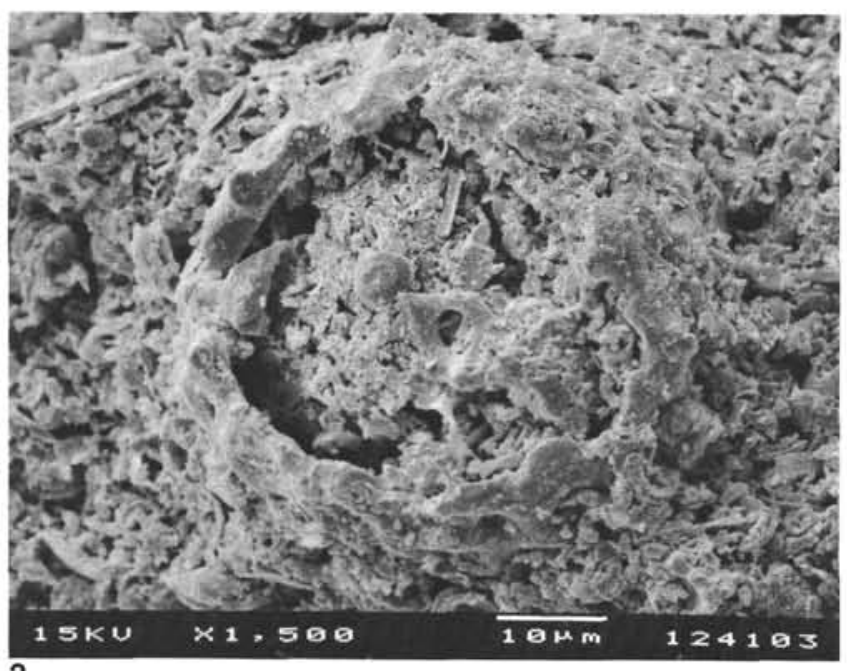

2

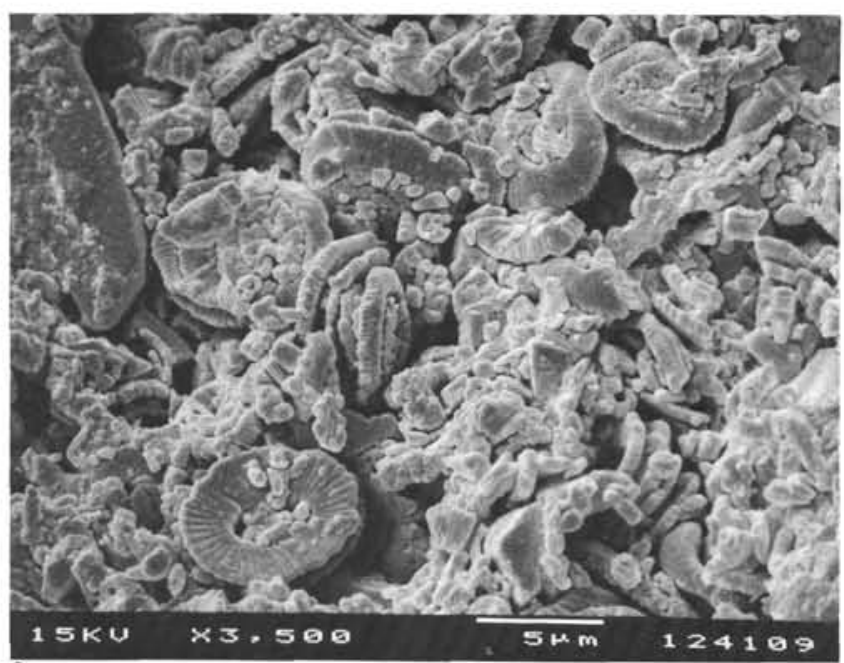
3

Plate 5. 1-3. Scanning electron photomicrographs of Sample 120-751A-12H-4, 117-119 cm, mixed siliceous-calcareous ooze, comparatively more calcareous (Unit II). (1) Matrix of nannofossils and nannofossil crystallites surrounding larger skeletal elements, such as the corroded spumellarian radiolarian to the upper left (r). (2) Detail of radiolarian in Figure 1; note that the test is broken and partially filled with matrix material. (3) Detail of matrix. 4-6. Sample 120-751A-13H-6, 30-32 cm, mixed siliceous-calcareous ooze, comparatively more calcareous (Unit II). (4) Matrix of nannofossils and nannofossil crystallites surrounding larger skeletal elements, such as the foraminifers shown here. (5) Note radiolarian skeleton (r) almost completely filled with matrix material. (6) Detail of matrix.

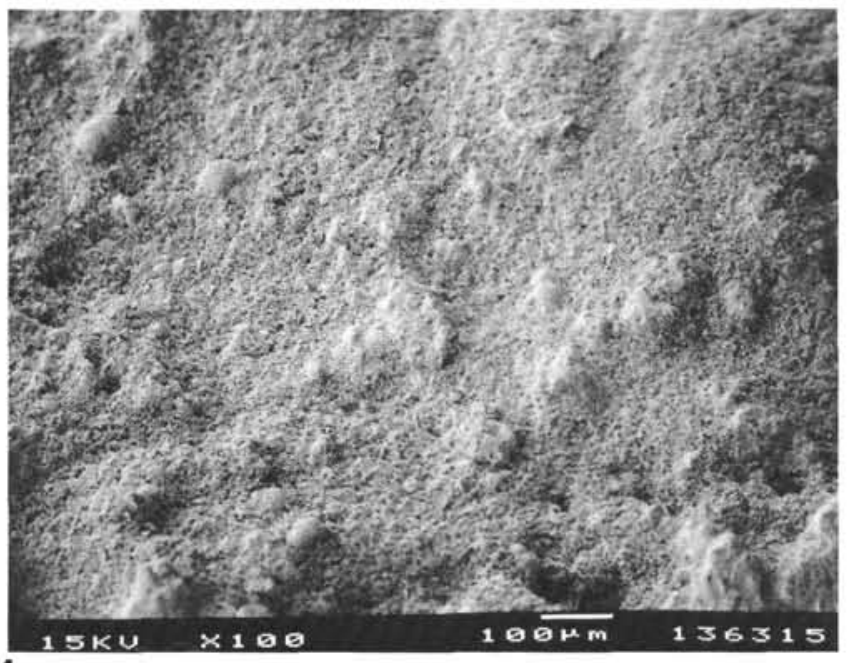

4
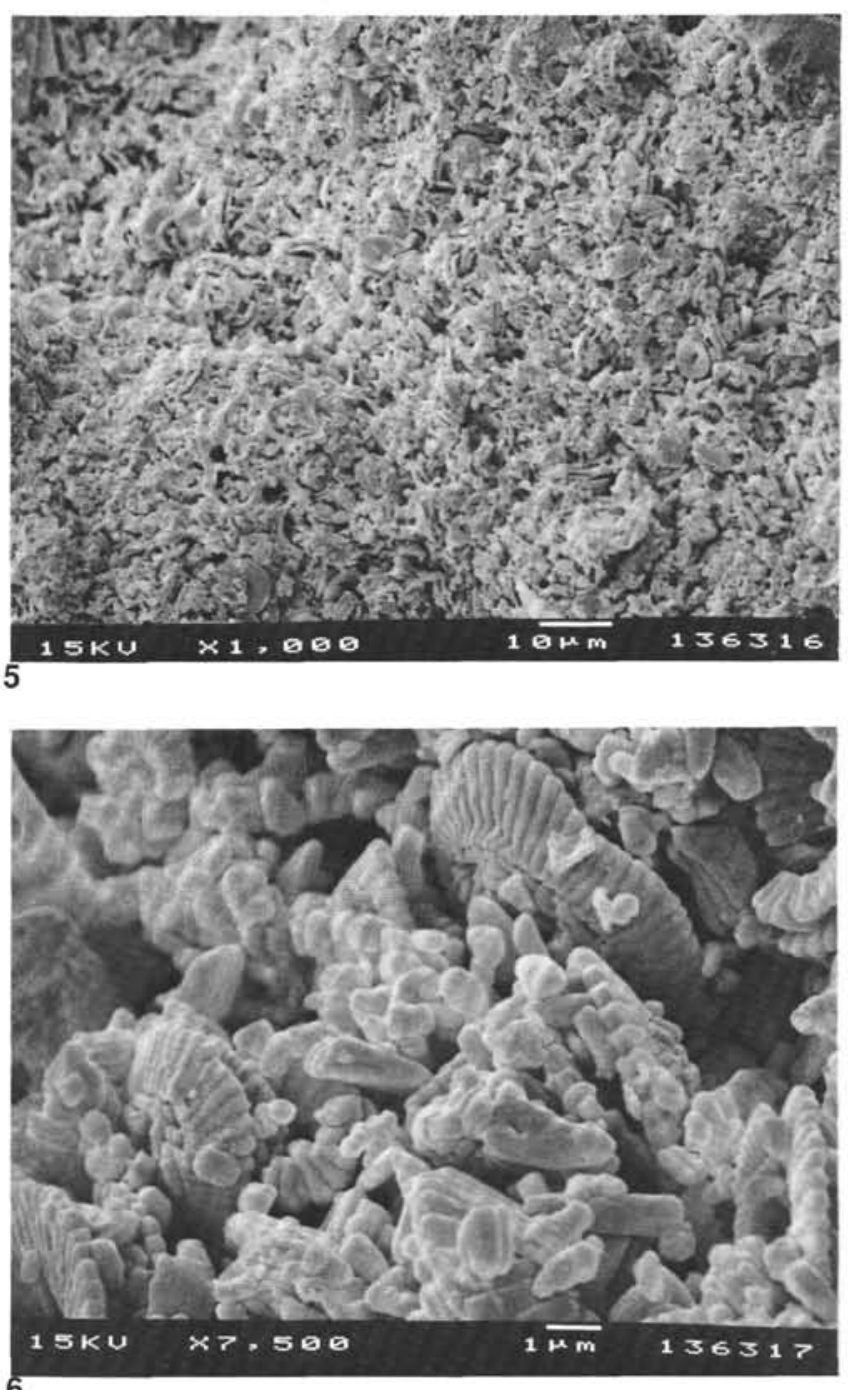

6 